\title{
Nomenclatural notes and new taxa in the genus Goodenia (Goodeniaceae)
}

\author{
Roger Carolin
}

\begin{abstract}
Carolin, Roger (John Ray Herbarium, University of Sydney, Australia 2006). 1990. Nomenclatural notes and new taxa in the genus Goodenia (Goodeniaceae). Telopea 3(4):517570. - Lectotypifications of a number of taxa in Goodenia are made and discussions of holotypes provided where necessary. The genera Calogyne, Catospermum, Neogoodenia and Symphyobasis are reduced to synonyms of Goodenia and the necessary new combinations are made. Forty-three taxa are described as new, i.e., G. arachnoidea, G. arenicola, G. argillacea, G. bellidifolia subsp. argentea, G. berringbinensis, G. byrnesii, G. campestris, G. convexa, G. chthonocephala, G. delicata, G. drummondii, G. durackiana, G. fordiana, G. glareicola, G. gloeophylla, G. heterophylla subsp. eglandulosa, G. heterophylla subsp. montana, G. integerrima, G. janamba, G. kakadu, G. kingiana, G. leiosperma, G. lyrata, G. macbarronii, G. malvina, G. muelleriana, G. nigrescens, G. ochracea, G. pallida, G. paludicola, G. pascua, G. potamica, G. perryi Gardner ex Carolin, G. phillipsiae, G. prostrata, G. racemosa var. latifolia, G. redacta, G. sepalosa var. glandulosa, G. tripartita, G. viridula, G. viscidula, G. watsonii subsp. glandulosa, $G$. willisiana. The rank of three taxa is changed, i.e., G. brachypoda (F. Muell.) Carolin, G. hederacea subsp. alpestris (Krause) Carolin, G. heterophylla subsp. teucriifolia (F. Muell.) Carolin. Sixteen new combinations are made as follows. Transferred from Calogyne: G. heteroptera (F. Muell.) Carolin, G. heppleana (W. Fitzg.) Carolin, G. holtzeana (Specht) Carolin, G. neglecta (Carolin) Carolin, G. pilosa (R. Br.) Carolin, G. porphyrea (Carolin) Carolin, G. purpurea (F. Muell.) Carolin, G. quadrifida (Carolin) Carolin, G. symonii (Carolin) Carolin. Transferred from Catospermum: G. goodeniacea (F. Muell.) Carolin. Transferred from Scaevola: G. helmsii (E. Pritzel) Carolin, G. fasciculata (Benth.) Carolin. Transferred from Neogoodenia, with a new specific epithet: G. neogoodenia Carolin. Transferred from Symphyobasis: G. macroplectra (F. Muell.) Carolin. Transferred from Velleia: G. cusackiana (F. Muell.) Carolin, G. salmoniana (F. Muell.) Carolin. A new name, G. krauseana, is provided for $G$. nana $\mathrm{K}$. Krause non Vriese. The name G. micrantha Hemsley is validated.
\end{abstract}

\section{Introduction}

This is the third in a series of contributions which provide a basis for the taxonomic treatment of the family Goodeniaceae in the Flora of Australia, vol. 35. Previous ones have dealt with the taxonomy, phylogeny, nomenclature and new taxa in Dampiera (Rajput and Carolin 1988) and Scaevola (Carolin 1990). The present one deals only with the nomenclature and new taxa in the genus Goodenia. A contribution is being prepared which will consider the phylogeny and taxonomy of Goodenia and its satellite genera. Most of the preliminary analyses have been carried out but it is necessary to formalise the proposed taxonomic changes before these aspects can be submitted for publication in order that the Flora of Australia vol. 35 may proceed.

If Calogyne, Catosperma, Neogoodenia and Symphyobasis are accepted at generic level, the genus Goodenia is rendered paraphyletic (Carolin, unpub.). Consequently they are here reduced to synonyms of Goodenia. The status of the genus Selliera remains ambiguous after the analyses, and consequently it is retained for the time being. 
Carolin (1967) provides a diagram which illustrates the terms used in describing the parts of the corolla.

The structure of this contribution is similar to the second part of the papers on Dampiera and Scaevola. Argument is provided by Rajput and Carolin (1988) for the selection of various types in the case of collections by R. Brown, $L$. Preiss, and E. Pritzel. Paralectotypes are given when more than one collection relates to the protologue. The asterisk, '*', indicates that only one collection relates to the protologue. The Guide to the Determination of Types in the International Code of Botanical Nomenclature has been followed to avoid possible arbitrary selection of lectotypes.

When a name is considered to be a synonym of another name, the name that is currently accepted is given after ' $=$ '.

When selected specimens are cited, the total number examined is indicated in parentheses.

The taxa are arranged in a supposedly natural sequence.

G. scapigera $R$. Br., Prodr.: 578 (1810).

LeCtotype: Western Australia: Bay 1 (Lucky Bay), R. Brown, 11 Jan. 1802 (BM). ISOLECTOTYPE: $K{ }^{*}$ Brown recognised two variants ' $\alpha$ ' and ' $\beta$ '. Both of these are represented on one sheet at BM although Brown has labelled none of the specimens as either $\alpha$ or $\beta$. Instead, the ones corresponding to $\beta$ are labelled ' $G$. affinis' and the others ' $G$. scapigera'. It seems clear from this that one must select the specimen labelled ' $G$. scapigera' by Brown as the lectotype and which he subsequently described as ' $\alpha$ '. $\beta$ is conspecific with $G$. decursiva.

G. scapigera var. foliosa F. Muell. ex Benth., Fl. Austral. 4: $57(1868)=$ G. decursiva $W$. Fitzg.

LeCtotype: Western Australia: Cape Arid and Cape Le Grand, Maxwell (K). The specimen second from the left on this sheet of mixed collections is selected.

G. decursiva W. Fitzg., West Australian Natural History Society 2: 25 (1905).

Lectotype: Western Australia: Esperance, C. Andrews, Oct. 1903 (PERTH). ISOLECTOTYPES: K, NSW 76592, PERTH.* There are two sheets at PERTH, both bearing the same label. One I have marked as the lectotype.

G. watsonii F. Muell. \& Tate, Trans. Roy. Soc. South Australia 16: 371 (1892) (as G. watsoni).

Lectotype: Western Australia: near Gnarlbine, R. Helms, 12 Nov. 1891. Elder Expl. Exped. (MEL 22128). IsolectotyPES: AD 96620133, K, MEL 22129, 22130, NSW 80794, 76581.*

G. watsonii subsp. glandulosa Carolin, subsp. nov.

Sepala et corolla extus glandulosa. Thyrsus laxus. Pedunculi pedicelli, ovaria, sepala ac extus corollae glandulose pubescentes. Corolla plerumque $4-5 \mathrm{~mm}$ longa, coerulea faucis flavis. Ovulae 12-16.

Holotype: Western Australia: 20 miles East of Hyden, J.S. Beard 3908, 12 Jan. 1965 (PERTH).

This differs from the type subspecies as follows: Thyrses loose. Peduncles, pedicels and outside of flowers glandular pubescent. Corolla usually $4-5 \mathrm{~mm}$ long, blue, with yellow throat. Ovules 12-16.

RANGE: Lake Grace-Hyden region in Western Australia. 
HaBITAT: Open woodland.

SPECIMENS EXAMINED: WeStern Australia: 8 miles $(12.8 \mathrm{~km}) \mathrm{W}$ of Lake Grace, $A . S$. George 520, 30 Jan. 1960 (PERTH); 16 miles $(25.6 \mathrm{~km})$ W of Lake Grace, W.E. Blackall 1314, 11 Nov. 1931 (PERTH); 12 miles $(19.2 \mathrm{~km})$ north of Lake Grace, P.R. Jefferies 641029, Oct. 1964 (PERTH).

The subspecific epithet refers to the glandular hairs on the inflorescence.

G. pinifolia Vriese, Natuurk. Verh. Holl. Maatsch. Wetensch. Haarlem ser. 2 10: 157 (1854).

Lectotype: Western Australia: Ad flumen cygnorum, Drummond, 1839 (K). ISOLECTOTYPE: MEL 22082. Vriese writes 'Herb. Hook et Lindley'. The former specimen has been selected as the lectotype.*

G. fasciculata (Benth.) Carolin, comb. nov.

Basionym: Scaevola fasciculata Benth. in Endl., Enum. Pl. Hueg.: 68 (1837).

Holotype: Western Australia: Swan River, Huegel (W).

G. squarrosa Vriese in J.G.C. Lehmann, P1. Preiss. 1: $413(1844)=$ G. fasciculata (Benth.) Carolin.

LeCtotype: Maddington, L. Preiss 1467, 2 Nov. 1839 (LD). IsOlectotype: K, MEL**

\section{G. drummondii Carolin, sp. nov.}

Frutex erectus ad $1 \mathrm{~m}$ altus. Folia crassa, linearia vel anguste obovata $1-4 \mathrm{~cm}$ longa integra vel dentata sessilia glabra. Folia lateralia fasciculata in axilis foliorum in caule principali. Flores pedunculis bracteolatis brevissimis. Corolla alba signis purpurascentibus c. $6 \mathrm{~mm}$ longa glabra extus lobis \pm aequalis palmatis alatis anguste. Ovulum unicum. Stylus $3.5 \mathrm{~mm}$ longus pilis purpureis pallide obtectus. Indusium oblongum. Nux globula c. $1 \mathrm{~mm}$ diametro.

Holotype: Western Australia: Drummond s.n. (MEL 21907). Supposed Isotypes: MEL 21902, 21905, $21907,21899$.

Erect glabrous shrub to $1 \mathrm{~m}$. Stems slight ly branched, echinate with persistent leaf-bases. Leaves thick, tending to form axillary fascicles, linear to very narrow-obovate, 1-4 cm long, 1-4 mm wide, sessile, acute, entire or with few narrow teeth, with few very short axillary hairs. Flowers in terminal and axillary spike-like thyrses to $20 \mathrm{~cm}$ long; bracts linear-triangular, $1-2 \mathrm{~mm}$ long, acute; bracteoles similar but smaller. Sepals narrow-ovate to almost linear, $1-1.5 \mathrm{~mm}$ long, $0.4-0.5 \mathrm{~mm}$ wide, acute, entire, wholly adnate to ovary only at base and above that by median line only for about $2 / 3$ its length. Corolla white with purplish markings at base of lobes, c. $6 \mathrm{~mm}$ long, glabrous outside, sprinkled with stiff white simple hairs inside especially on veins, without auricles; anterior pocket obscure, c. $1 / 2$ as long as ovary; tube c. $2.8 \mathrm{~mm}$ long; lobes almost equal, narrow-ovate to narrow-elliptic, $2.5 \mathrm{~mm}$ long, $0.5 \mathrm{~mm}$ wide; wings $0.3-0.4 \mathrm{~mm}$ wide; connate part of inferior lobes $0.3-0.4 \mathrm{~mm}$ long. Stamen filaments linear, c. $4 \mathrm{~mm}$ long; anthers narrow-oblong, c. $1 \mathrm{~mm}$ long. Ovary.septum minute; ovule solitary, erect; style $3.5 \mathrm{~mm}$ long, geniculate, with short stiff purplish simple hairs and some minute glandular ones; indusium oblong, c. $1 \mathrm{~mm}$ long, pale brown, not folded, glabrous or with a few hairs at base, with a \pm straight orifice beset with minute bristles. Fruit an inferior nut, globular c. $1 \mathrm{~mm}$ diam., glabrous except for prominent pubescent beak. Seed \pm compressed, brownish, ellipsoid, c. $1 \mathrm{~mm}$ long, smooth; rim and wing obsolete.

RANGE: Austin and Irwin Regions in Western Australia. 
HABITAT: Woodlands and heaths on sandy soils.

Discussion: This species was previously included under $G$. stenophylla (as Scaevola stenophylla) from which it differs in its smaller flowers with narrower corolla wings, narrower sepals, consistently a single ovule in the ovary and the considerably broader and frequently dentate leaves. It is also separated from $G$. stenophylla by a very considerable geographic discontinuity. In fact, it is more closely related to $G$. helmsii, from which it differs in the larger leaves.

Selected Specimens (15): Western Australia: Latham, D.A. Sargent 1372, 23 Oct. 1921 (MEL 21908); 2 miles (3.2 km) along Balla Road from Geraldton-Carnarvon Hwy., A.C. Burns 1070, 30 Oct. 1966 (PERTH); 27 miles $(43.2 \mathrm{~km})$ E of Kalbarri, A.S. George 7926, 8 Sept. 1966 (PERTH); Moresby Range, A.C. Burns 6, 19 Sept. 1965 (PERTH); Drummond 365 (MEL 21900, 21898, K).

Named for the collector of the type specimen, James Drummond, a famous collector of plants in Western Australia in the last century.

G. helmsii (E. Pritzel) Carolin, comb. nov.

Basionym: Scaevola helmsii E. Pritzel, Bot. Jahrb. Syst. 35: 572 (1905).

LeCtotype: Western Australia: In distr. Coolgardie haud procul Southern Cross, $E$. Pritzel 881 (NSW 76565). IsOlectotyPES: B (destroyed), K. PARALECTOTYPES: In distr. Avon interiore prope Tammin, Diels 2866 (B destroyed); In distr. Coolgardie haud procul Southern Cross, Diels 5591 (B destroyed).

G. viscida $R$. Br., Prodr.: 578 (1810).

LectotyPe: Western Australia: Bay 1, orae australis Nova Hollandia, $R$. Brown, 12 Jan. 1802 (BM). ISOLECTOTYPE: K*.

G. acuminata R. Br., Prodr.: $546(1810)=$ G. ovata Sm.

LeCtotype: New South Wales: Grose River, R. Brown, 1803 (BM). IsOlectotypes: K, MEL.*

G. varia $R$. Br., Prodr.: 576 (1810).

LeCtotype: SOUth Australia: Bay III S. Coast, R. Brown, s.d. (BM). ISOlectotyPes: K, MEL.*

G. mollis R. Br., Prodr.: 577 (1810)= G. grandiflora Sims

LECTOTYPE: QUEENSLAND: In monte prope Upper Lead, Broad Sound, R. Brown, s.d. (BM). ISOLECTOTYPES: K, MEL.*

G. horniana F. Muell. \& Tate ex Tate in Spencer, Report on the work of the Horn Scientific Exploring Expedition to Central Australia 3: 189 (1896).

LeCtOTYPE: NORTHERN TERritory: George Gills Range, $R$. Tate, June 1894 (AD 97601116). IsOLECTOTYPES: MEL 23313, 23050, 23049, K.* Mueller and Tate mention the binomial in Trans. \& Proc. Roy. Soc. South Australia 19: 82 (1895), but no description is supplied. The name was first published with a description by Tate himself as indicated. It is likely that all the specimens were available to the authors when they cast their description.

\section{G. chambersii F. Muell., Fragm. 1: 204 (1859).}

LeCTOTYPE: SOUTH AuSTRAlia: North western South Australia, J. M'Douall [sic] Stuart (MEL). ISOLECTOTYPE: $\mathrm{K}$. There has been some confusion, probably introduced by Bentham, over the type of this species. He cites 'J. M'douall Stuart's' specimen from Mt Freeling under both $G$. grandiflora and $G$. chambersii. This specimen has no connection with Mueller's original description of $G$. chambersii. Mueller himself, in fact, identified 
it as G. grandiflora (MEL 23113). Since Mueller's original description of G. chambersii was published in 1859 , it must be related to specimens collected before that date. Unfortunately, none of Stuart's specimens are dated. However, he did not reach Mt Freeling, in the Reynolds Range, until April 1860. Any specimens from this locality can, therefore, have no significance here. The specimens from north-western South Australia, labelled ' $G$. chambersii' by Mueller, must be the authentic ones used by him. Before 1859 Stuart had made only one well-documented journey into the north-west of $\mathrm{S}$. Australia. It is unlikely that he did much travelling west of Lake Torrens previously. This first journey was completed in late 1858 and it was probably during this that the specimens were collected, possibly in the ranges to the west of the Lake Eyre Basin.

\section{G. kingiana Carolin, sp. nov.}

Herba erecta suffruticosa vel frutex parvus usque $1.5 \mathrm{~m}$ altus. Folia lyratopinnatifida; lamina principalis ovata cordata grosse dentata pilis glandulosis et brevissimis simplicibus obtecta; pinnae laterales ovatae vel lineares petiolulatae. Flores pedunculis bracteolatis pedicellisque articulatis in racemis terminalibus dispositi. Corolla flava $2.5-3 \mathrm{~mm}$ longa glanduloso-pubescens extus et seriebus enationum prominentibus intus. Ovarium glandulosopubescens. Fructus late ovoideus $8 \mathrm{~mm}$ longum duabus valvis dehiscens.

Holotype: Western Australia: 16 miles $(25.6 \mathrm{~km})$ E of Kalli, N.H. Speck 1052, 22 July 1958 (CANB 109430). IsOTYPES: AD 96003018, BRI 020575, K.

Erect, viscid, suffruticose plant or undershrub to $1.5 \mathrm{~m}$ high. Stems ridged when young but becoming \pm terete, pubescent with both long and short glandular hairs but scarcely any simple hairs. Leaves lyrate-pinnate; terminal lamina ovate, $2-4 \mathrm{~cm}$ long, $1-2.5 \mathrm{~cm}$ wide, cordate at base, acute, coarsely dentate, glandular-pubescent with long and short hairs but also with a very short simple pubescence; lateral pinnae much smaller, ovate to linear, when ovate always distinctly petiolulate; petiole $3-7 \mathrm{~cm}$ long, slender. Flowers in terminal leafy racemes, rarely thyrses; peduncles $3-10 \mathrm{~mm}$ long, glandular-pubescent; bracteoles linear to oblanceolate or narrow-elliptic, 5-10 mm long, $1-1.5 \mathrm{~mm}$ wide, acute, entire or with a few lobes at base, usually \pm petiolate, glandularpubescent; pedicel 15-20 mm long, similar to peduncle, articulate just below ovary. Sepals lanceolate, 4-5 $\mathrm{mm}$ long, c. $1.0 \mathrm{~mm}$ wide, acute, entire, glandular-pubescent, adnate to ovary nearly to its summit. Corolla yellow, 2.5-3 cm long, glandular-pubescent with a few short simple hairs outside, villous-hirsute towards base, with rows of very prominent enations inside, scarcely auriculate; anterior pocket \pm prominent, c. $2 / 3$ as long as ovary; tube 5-6 mm long; superior lobes narrow-oblong, c. $2 \mathrm{~cm}$ long, 3-4 mm wide; inferior lobes oblong-elliptic, 14-16 $\mathrm{mm}$ long, 5-6 $\mathrm{mm}$ wide, central one slightly broader than laterals; wings $3-4 \mathrm{~mm}$ wide; connate part of inferior lobes 10-12 mm long. Stamen filaments linear, 8-9 mm long; anthers narrowoblong, $3.5 \mathrm{~mm}$ long, $0.8 \mathrm{~mm}$ wide. Ovary glandular-pubescent; septum about $2 / 3$ as long as loculus; ovules $20-26$; style c. $25 \mathrm{~mm}$ long, sparsely villous; indusium depressed-ovate, $3 \mathrm{~mm}$ long, $6 \mathrm{~mm}$ wide, yellow-brown, \pm concave, with a slightly curved orifice beset with white bristles c. $0.5 \mathrm{~mm}$ long. Fruit broad-ovoid, $8 \mathrm{~mm}$ long, $6 \mathrm{~mm}$ wide, glandular-pubescent, with a distinct beak, 2 -valved probably to base at maturity, each valve not or only shortly bifid. Seeds flat, only immature ones seen.

Range: Austin Region in Western Australia.

HABITAT: Feet of lateritic "breakaways".

Discussion: This species differs from $G$. grandiflora and its closer relatives in the longer glandular hairs, the larger flowers with broader wings making a more 
acute angle at the apex, and the petiolulate segments below the main lamina of the leaf.

SPecimens EXamined: Western Australia: 43 miles $(68.8 \mathrm{~km})$ SE of Mileura, N.H. Speck 696, 7 Sept. 1957 (CANB 109429); $60 \mathrm{~km}$ NW of Cue, P.G. Wilson 9901, 1 Sept. 1970 (PERTH); Near Lake Austin, H.S. King, 1886 (MEL 23909, MEL 23091); Tching Range, W.J. Peacock 60858.1, 15 Aug. 1960 (SYD); Cue, W.D. Campbell, June 1902 (K); 3 miles $(4.8 \mathrm{~km}) \mathrm{E}$ of Cue, C.A. Gardner, 28 July $1927(\mathrm{~K})$.

Named in honour of H.S. King who first collected this species.

G. amplexans F. Muell., Trans. \& Proc. Philos. Inst. Victoria 2: 70 (1858).

Lectotype: South Australia: Foot of the Mount Lofty Ranges (MEL 23844). PARAlectotyPes: Banks of the Torrens River, F. Mueller, Jan. 1848 (MEL22300); Nile Rivulet, s.c., Nov. 1848 (MEL 23854). In the protologue Mueller gives as locality "Ridges and gullies near Adelaide". There are no specimens labelled in that way and the one selected as the lectotype is the only one collected in the area in question and annotated by Mueller with the name Goodenia amplexans.

\section{G. fordiana Carolin, sp. nov.}

Herba prostrata pubescens confertim molliter pilis simplicibus pro parte maxima induta. Scapi usque $20 \mathrm{~cm}$ longi in axillis foliorum rosulatorum inserti. Folia rosulata distincte petiolata: lamina elliptica vel late elliptica $10-25 \mathrm{~mm}$ longa 8-14 $\mathrm{mm}$ lata obscure dentata. Flores distantes pedicellis non articulatis, $1-1.5 \mathrm{~cm}$ longis in racemis foliosis dispositi. Corolla flava $8-10 \mathrm{~mm}$ longa seriebus enatiorum intus. Indusium transverse ellipticum. Fructus et semina non videntur.

Holotype: New South Wales: Bushman Range near Coramba, W. Heron, Oct. 1913 (NSW 76620).

Prostrate herb, pubescent with soft simple and multicellular hairs, with a thin tap root and a distinct persistent rosette of leaves in axils of which arise leafy scapes to $20 \mathrm{~cm}$ long. Basal leaves narrowing abruptly into a \pm distinct petiole 1-3 cm long; lamina elliptic to broad-elliptic, 10-25 $\mathrm{mm}$ long, 8-14 mm wide, obscurely dentate to entire, obtuse, softly pubescent with mostly simple hairs on both surfaces, denser on lower surface; cauline leaves smaller. Flowers distant in leafy racemes; peduncles $1-2 \mathrm{~cm}$ long, pubescent; bracteoles linear, 2 $\mathrm{mm}$ long, $0.2 \mathrm{~mm}$ wide, acute, pubescent; pedicels $1-1.5 \mathrm{~cm}$ long, similar to peduncles, not articulate. Sepals linear, $2.5 \mathrm{~mm}$ long, $0.5 \mathrm{~mm}$ wide, acute, pubescent, adnate to ovary almost to its summit. Corolla yellow, $8-10 \mathrm{~mm}$ long, pubescent with soft mostly simple hairs outside, \pm pubescent inside towards base, with rows of distinct enations, auriculate; anterior pocket less than $1 / 2$ as long as ovary; tube $1.5 \mathrm{~mm}$ long; superior lobes narrow-oblanceolate, $5 \mathrm{~mm}$ long, $1 \mathrm{~mm}$ wide; inferior lobes elliptic, c. $3.5 \mathrm{~mm}$ long, $1.5 \mathrm{~mm}$ wide; wings 2 $\mathrm{mm}$ wide; connate part of inferior lobes c. $4 \mathrm{~mm}$ long. Stamen filaments linear, c. $1.5 \mathrm{~mm}$ long; anthers broad-elliptic, $0.5 \mathrm{~mm}$ long, with a short broad mucro. Ovary pubescent; septum c. $1 / 2$ as long as loculus; ovules $24-28$; indusium transverse-elliptic, $0.7 \mathrm{~mm}$ long, $1.2 \mathrm{~mm}$ wide, scarcely folded, villouspubescent, with a curved orifice beset with white bristles c. $0.1 \mathrm{~mm}$ long on both lips. Fruit and seed not known.

RANGE: North Coast District of New South Wales.

HABITAT: Forests and woodlands.

DisCUSSION: In some respects this species resembles $G$. rotundifolia, from which it can be distinguished by the softer pubescence, longer pedicels, more slender scapes with long internodes and the almost entire leaves. 
Specimens examined: New South Wales: North Coast: Lookout Road, Bellangry State Forest, J.C. Cousins, 23 Oct. 1958 (NSW 76619); Bulahdelah, H.M.R. Rupp, 12 Nov. 1923 (NSW 76621).

Named for Neridah Ford formerly of the National Herbarium of N.S.W. who first recognized this species and kindly drew my attention to it.

G. taylorii F. Muell. (as G. taylori), Fragm. 3: 141 (1862) = G. quadrilocularis $R$. $\mathrm{Br}$.

Lectotype: Western Australia: Orleans Bay, (Maxwell?) (MEL 22084). Possible ISOLECTOTYPE: K.* There is some confusion about the type of $G$. taylorii F. Muell. and the specimen which Mueller cites in Fragm. 6: 13 (1867) as G. quadrilocularis. The locality given for these two specimens in each case refers to '... in collibus arenosis ... Orleans Bay'. The descriptions are really very similar in important features, allowing for the fact that they were drawn up at different times.

There is only one specimen agreeing with these descriptions, collected in sand hills at Orleans Bay and housed in MEL. It is labelled ' $G$. quadrilocularis $R$. Br'. Since this agrees with the description of $G$. taylorii, particularly with regard to the indumentum of the corolla, shape of the capsule and of the leaf, I am selecting this as the lectotype. It appears that Mueller (Fragm. 6: 13) used both this specimen and 'Towards the Great Bight' (MEL 22083), in casting his later description of G. quadrilocularis.

I have been unable to find any specimen at MEL, or elsewhere, labelled ' $G$. taylori'.

G. decurrens $R$. Br., Prodr.: 575 (1810).

Lectotype: New South Wales: Banks of Grose River, R. Brown, 1803 (BM). ISOLECTOTYPES: $\mathrm{K}$, MEL, P.*

G. dimorpha Maiden \& Betche, Proc. Linn. Soc. New South Wales 28: 907 (1904).

Lectotype: New South Wales: Woodford, Blue Mts., J.H. Maiden, Jan. 1899 (NSW); Isolectotype: MEL. Paralectotypes: Springwood, Blue Mountains, E. Betche, Feb. 1884 (NSW); Blackheath, Blue Mountains, A.A. Hamilton, Jan. \& April, 1900 (MEL, NSW).

G. dimorpha var. angustifolia Maiden \& Betche, Proc. Linn. Soc. New South Wales 28: 907 (1904).

Lectotype: New South Wales: National Park, J.L. Boorman, Jan. 1903 (NSW). PARALECTOTYPE: National Park, J.L. Boorman, Jan. 1903 (NSW).

G. stelligera $R$. Br., Prodr.: 575 (1810).

Lectotype: New South Wales: Port Jackson (inter Sydney \& South Head), R. Brown, May-June 1802 (BM). ISOLECTOTYPES: K, MEL, P.

G. rostrivalvis Domin, Biblioth. Bot. 22: 1193 (1929).

Lectotype: New South Wales: Sandsteinhugel in dem Blue Mountains bei Katoomba, Domin, April 1910 Domin (PR). PARALECTOTYPE: ohne nahere Standortsangabe, $A$. Cunningham (K).

G. bellidifolia var. ramosissima K. Krause, Pflanzenr. 54: 50 (1912). = G. bellidifolia $S m$. subsp. bellidifolia.

Holotype: New South Wales: ohne genauen Standorts, Caley (B, destroyed). LECTOTYPE: The former isotype at BM. ISOLECTOTYPE: W.

G. bellidifolia subsp. argentea Carolin, subsp. nov.

Folia ovata in petiolum gradatim decrescentes. Corolla villosa albide gossypine extus. Stylus plerumque glaber indusio plerumque oblongo $1 \mathrm{~mm}$ longo $0.6 \mathrm{~mm}$ 
lato bicanaliculato infra setis super labio $0.2 \mathrm{~mm}$ longis. Capsula globula c. 2 mm diametro.

Holotype: New South Wales: 18 miles west of Emmaville, W.J. Peacock 6111.23.1, s.d. (NSW).

Perennial with a basal stock. Leaves in an ascending rosette, usually ovate, narrowing gradually into a short petiole. Corolla with few short appressed yellow hairs, which are scarcely visible without a x10 magnification, and numerous multicellular cottony hairs on outside. Style usually glabrous but for a few villous hairs towards top; indusium oblong or rarely slightly obovate, 1.0 $\mathrm{mm}$ long, c. $0.6 \mathrm{~mm}$ wide with a double groove and a single usually villous ridge below; indusium bristles usually less than $0.2 \mathrm{~mm}$ long. Fruit globular to subglobular, c. $2.0 \mathrm{~mm}$ diam. Seeds very dark brown to black.

RANGE: Northern parts of the Western Slopes, Tablelands and Coastal Districts of New South Wales; Darling Downs, Moreton and Wide Bay Districts of Queensland.

HABITAT: Grassland, scrubs and woodlands.

Discussion: See Peacock (1962).

Selected Specimens (106): New South Wales: Maryland, E. Hickey 101, Dec. 1884 (MEL 22017); Wallangarra, J.L. Boorman, Nov. 1912 (NSW 76795); Jennings, J.L. Boorman, Dec. 1903 (NSW 76810); Lookout Point, near Inverell, P.B. Oelrich AR921, 28 March 1950 (CANB 79360); Ben Lomond, R.A. Boyd, 25 Jan. 1955 (AD 95809061); 3 miles $(4.8 \mathrm{~km}$ ) N. of Bundarra, W.J. Peacock 6111.14.1, s.d. (SYD); Barcoongere SF., W.J. Peacock 6012.2.5, 10 Dec. 1960 (SYD); Laurieton, J.L. Boorman, Nov. 1915 (NSW 76503).

Named for the silvery hairs on the corolla; Latin, argenteus $=$ silvery.

G. racemosa $F$. Muell., Fragm. 1: 114 (1859).

LeCTOTYPE: QUEENSLAND: Burnett River, $F$. Mueller, Nov. 1856 (MEL). IsOlectotyPES: $\mathrm{K}$, MEL.

\section{G. racemosa var. latifolia Carolin, var. nov.}

Folia anguste oblonga. Corolla alis angulatis acute. Indusium depresse ovatum. Holotype: QUEENSLAND: Isla Gorge, 16 miles $(25.6 \mathrm{~km}) \mathrm{SSW}$ of Theodore, $F . D$. Hockings 11, 1 Sept. 1963 (BRI 045529).

Differs from the type variety as follows: Leaves narrow-oblong, 7-10 mm wide. Corolla wings with \pm acute angles, c. $1.6 \mathrm{~mm}$ wide; auricles conspicuous, pubescent; inferior lobes c. $5 \mathrm{~mm}$ long. Indusium depressed-ovate.

RANGE: Leichhardt District of Queensland.

HABITAT: Rocky situations.

SPECIMEN EXAmined: QueEnsLand: Isla Gorge, S. L. Everist 8060, 28 Sept. 1968 (BRI 151669).

Named for the leaves which are wider than those of the type variety. Latin, latus $=$ wide, folium $=$ leaf .

G. disperma F. Muell., Fragm. 1: 113 (1859).

Lectotype: Queensland: Dawson River (MEL). Isolectotype: K. Paralectotypes: Uncertain. Mueller writes in the protologue, 'Inter campis sub-arenosis ad pedes montium inter flumina MacKenzie, Dawson, et Burnett'. I have not located any specimens from the Mackenzie or Burnett Rivers in MEL. 
G. sessiliflora F. Muell., Fragm. 4: $145(1864)=$ G. disperma $F$. Muell. Lectotype: QueEnSLAND: Cape River, Bowman 231 (MEL 24292). Paralectotype: Cape River, Bowman 287. Only these two specimens agree with the locality and collector given in the protologue; Mueller gives no numbers. Both agree with the description in the protologue and the most complete specimen has here been chosen.

\section{G. viridula Carolin, sp. nov.}

Frutex ascendens ramificatus usque $40 \mathrm{~cm}$ altus. Caules tomenti denso albido vel flavo-albido pilis multicellularis gossypine obtecti. Folia linearia ubi juvenilia tomentosa gossypine marginibus revolutis. Flores sessiles in spicis terminalibus dispositi. Corolla viridula c. $4.5 \mathrm{~mm}$ longa gossypine extus pubescens dense in fauce intus sacco obsoleto. Capsula subglobosa $3 \mathrm{~mm}$ lata seminibus duobus oblongo-ellipticis c. $3 \mathrm{~mm}$ latis ora prominenti sed ala angusta.

HolotyPe: QueEnSLAND: c. 5 miles $(8 \mathrm{~km})$ east of Jericho, L.S. Smith \& S.L. Everist 97842, Oct. 1940 (BRI 067478). ISOTYPES: CANB 12903, MEL 22355, K).

Ascending much-branched undershrub to $40 \mathrm{~cm}$. Stems obscurely ridged when young but becoming terete, covered with a dense white or yellowish white cottony tomentum of multicellular hairs. Leaves linear, $1.5-5 \mathrm{~cm}$ long, $0.5-1.1$ $\mathrm{mm}$ long, cottony tomentose when young, sessile, acute, entire, margins revolute but often becoming flatter towards tips, glabrescent, with a dense tuft of villous axillary hairs. Flowers sessile, in \pm terminal spikes; bracteoles linear, to $2 \mathrm{~mm}$ long. Sepals triangular to ovate, $0.8-1 \mathrm{~mm}$ long, c. $0.5 \mathrm{~mm}$ wide, acute, entire, sprinkled with cottony hairs, united to ovary nearly to its summit. Corolla greenish yellow, 4-9 $\mathrm{mm}$ long, sprinkled with multicellular cottony hairs on outside, densely villous in throat, auriculate; anterior pocket very short and obscure; tube 1-2 mm long; superior lobes narrow-oblong, 2-2.5 $\mathrm{mm}$ long, c. $0.5 \mathrm{~mm}$ wide; inferior lobes ovate, $2-4 \mathrm{~mm}$ long, $1 \mathrm{~mm}$ wide; wings $0.5 \mathrm{~mm}$ wide; connate part of inferior petals $1.5-2.5 \mathrm{~mm}$ long. Stamen filaments linear, c. $1.5 \mathrm{~mm}$ long; anthers oblong, c. $0.5 \mathrm{~mm}$ long. Ovary cottony-tomentose; septum scarcely $1 / 2$ as long as loculus; ovules $4-6$; style $1.2-1.5 \mathrm{~mm}$ long, \pm villous towards base; indusium oblong, $1 \mathrm{~mm}$ long, $0.7 \mathrm{~mm}$ wide, brownish, not folded, with a very curved orifice beset with white bristles c. $0.3 \mathrm{~mm}$ long on upper lip and much shorter ones on lower lip; upper lip distinctly longer than lower one. Fruit subglobular, c. $3 \mathrm{~mm}$ diam., cottony-tomentose but for almost glabrous beak, 2-valved. Seed flat, yellow-brown, oblong-elliptic, c. $3 \mathrm{~mm}$ long, $1 \mathrm{~mm}$ wide, reticulate, with a prominent rim; wing narrow.

RANGE: South Kennedy and Mitchell Districts of Queensland.

HABITAT: Open woodlands and heaths.

Discussion: This differs from $G$. disperma in the densely tomentose stems, linear revolute leaves and the smaller and greenish yellow flowers.

SPECIMEN EXAMINED: QUEENSLAND: Jericho, M.S. Clemens, April 1946 (BRI 067376).

Named for the greenish yellow corolla. Latin, viridulus $=$ greenish.

\section{G. delicata Carolin, sp. nov.}

Herbae ascendentes vel decumbentes radice tenui, sparsim arachnopubescentes pilis multicellularibus saepe glabrescentes. Caules scapique usque $50 \mathrm{~cm}$ longi. Folia linearia usque anguste elliptica, 2-6 cm longa, 2-6(-13) $\mathrm{mm}$ lata integra vel dentibus paucis grossis versus basin sensim in petiolum indistinctum contracta. Flores in racemis foliosis dispositi; bracteolae lineares; pedicelli non articulati. Corolla flava sine enationibus, $10-13 \mathrm{~mm}$ longa; alis 
1-1.5 mm latis; lobi superiores auriculati. Fructus globularis c. $8 \mathrm{~mm}$ diametro duabus valvis bifidis dehiscens. Semina plana, elliptico-oblonga reticulata ora crassa sed ala angustissima.

Holotype: QueEnSLAND: 13 miles $(20.8 \mathrm{~km}) \mathrm{W}$ of Westmar, L. Pedley 506, 15 Oct. 1959 (BRI 026704).

Ascending to decumbent, short-lived herb with thin tap root. Stems terete, condensed or elongated, with an indistinct rosette of leaves, with scapes to 50 $\mathrm{mm}$ long, arachnoid-pubescent when young but glabrescent. Leaves linear to narrow-elliptic, $2-6 \mathrm{~cm}$ long, $2-13 \mathrm{~mm}$ wide, narrowing very gradually into an indistinct petiole, acute, entire or with few coarse teeth, slightly recurved or slightly thickened at margin, sparsely arachnoid-pubescent with multicellular and sometimes simple hairs when young, often glabrescent especially above. Flowers in leafy racemes; peduncles slender, mostly 5-20 mm long, sparsely arachnoid and simple-pubescent to almost glabrous; bracteoles linear, 1-2 mm long, c. $0.5 \mathrm{~mm}$ wide, acute, pubescent to glabrescent; pedicels $5-10 \mathrm{~mm}$ long, not articulate, similar to peduncles. Sepals linear-ovate, $2-2.5 \mathrm{~mm}$ long, c. 0.5 $\mathrm{mm}$ wide, acute, sparsely arachnoid and simple-pubescent to almost glabrous, adnate to ovary nearly to its summit. Corolla yellow, 10-13 mm long, sparsely arachnoid-pubescent with multicellular hairs and some simple ones on outside often more numerous towards top, very sparsely pubescent towards base and without enations inside; anterior pocket almost obsolete; tube 4-5 mm long; superior lobes falcate-narrow-elliptic, 6-7 $\mathrm{mm}$ long, c. $1 \mathrm{~mm}$ wide; inferior lobes narrow-oblong, 4-4.5 mm long, c. $1.5 \mathrm{~mm}$ wide; wings c. $1 \mathrm{~mm}$ wide; connate part of inferior lobes 6-7 mm long. Stamen filaments linear, $3 \mathrm{~mm}$ long; anthers linear, $1.5 \mathrm{~mm}$ long, minutely apiculate. Ovary sparsely arachnoid and simple-pubescent; septum c. $1 / 2$ as long as loculus; ovules c. 12 ; style $4-5 \mathrm{~mm}$ long, glabrous, slightly geniculate; indusium very broad-elliptic, $1 \mathrm{~mm}$ long, 1.5 $\mathrm{mm}$ wide, purple-brown, glabrous, with a very slightly concave orifice beset with white bristles c. $0.1 \mathrm{~mm}$ long on both lips. Fruit globular, c. $8 \mathrm{~mm}$ diam., pubescent to almost quite glabrous, with a glabrous beak, 2-valved, each valve bifid for c. $1 / 2$ its length and spreading. Seeds flattened, pale yellow, ellipticoblong, $2 \mathrm{~mm}$ long, aculeate; wing c. $0.1 \mathrm{~mm}$ wide.

Range: Western Plains of New South Wales; Darling Downs, Burnett and Wide Bay Districts of Queensland.

Habitat: Forests and woodlands.

Discussion: This species has been confused with $G$. geniculata by Bailey, Qld. Fl.: 898 (1900) etc. It differs from other species of the $G$. hederacea group in the very sparse indumentum and narrow leaves. The leaves are often almost entire. When simple hairs are present they are very short, patent and soft. The capsule is globular as compared with more elongated capsules in other members of the group.

Selected Specimens (11): Queensland: Mt Perry, J. Keys (BRI I067585, 067586); Eidsvold, H.S. McKee 10230, 3 April 1963 (CANB 139062); Biggenden, C.T. White 7280, 11 Oct. 1930 (BRI 067567, 067568); Gayndah, G.J.E. Schoneveld 249, 1960 (BRI 1024882); Gurulmundi, R.W. Johnson \& L. Pedley 42, 29 June 1955 (BRI 067566); 3 miles $(4.8 \mathrm{~km}) \mathrm{N}$ of Glenmorgan, W.J. Peacock 6111.36.2, s.d. (SYD); 15 miles (24 km) N of Jackson, $R$. Melville 3466, 25 March 1953 (NSW 88354).

Named for the Darling Downs on which it occurs. Latin, delicatus = darling.

G. heterophylla subsp. eglandulosa Carolin, subsp. nov.

G. heterophylla subsp. 'B' Jacobs \& Pickard, Plants of N.S.W.: 133 (1981). 
Herbae ascendentes usque erectae pubescentes pilis simplicibus et multicellularibus nonnumquam glabriusculae. Folia ovata, serrata dentibus saepissime distincte mucronatis et marginibus recurvatis.

HolotyPE: New South Wales: South end of Jervis Bay, F.A. Rodway, Oct. 1954 (NSW 100834).

Ascending to erect herb with simple and multicellular hairs, sometimes glabrescent. Leaves ovate, $1-3 \mathrm{~cm}$ long, serrate, each tooth mucronate, sometimes with two basal lobes; margin recurved.

RANGE: Coastal Districts of New South Wales.

HABITAT: Frequently on deep sands but also on the massive sandstones of the Budawang Range near Milton. Also known from other rock formations in the Bulahdelah - Barrington Tops area.

Discussion: Differs from the type subspecies in the pubescence of simple and multicellular hairs with no glandular hairs and although it is sometimes glabrescent; leaves ovate, serrate, each tooth \pm mucronate, with recurved margins. The relationship of this and the type subspecies is discussed by $\mathbf{J}$. Hufton (Hons. Thesis University of Sydney, 1972).

Selected Specimens (44): New South Wales: Bargoongarie Forest, W.J. Peacock 6012.2.3, 10 Dec. 1960 (SYD); Wallis Lake, H. Salasoo 3312, 6 Jan. 1967 (NSW 1O0618); Boolambayte Lake, J. Hufton 11, 1972 (SYD); Alum Mt, E.F. Constable 4294, 26 Aug. 1963 (NSW 71139); Kogarah, J.H. Camfield, Nov. 1896 (NSW 81425); Lower Budgong road 3 miles $(4.8 \mathrm{~km}) \mathrm{N}$ of Shoalhaven River, L.A.S. Johnson \& E.F. Constable, 24 Nov. 1960 (NSW 50178); Turpentine Range, J. Hufton 35, 1972 (SYD)

The epithet refers to the lack of glandular hairs which are found in the type subspecies. Latin, $e^{-}=$without, glandulosus $=$glandular.

G. heterophylla subsp. teucriifolia ( $F$. Muell.) Carolin, comb. nov.

BASIONYM: G. teucriifolia F. Muell., Trans. \& Proc. Philos. Inst. Victoria 2: 70 (1858).

LeCTOTYPE: QueENSLAND: Moreton Bay, Glasshouse Mts., s. c. (MEL 23907). IsoLECTOTYPES: MEL 23911, 23908 pro parte, $\mathrm{K}$. There are three sheets of this taxon at MEL bearing specimens from this locality; only one is annotated as 'G. heterophylla $\mathrm{Sm}$. var teucriifolia'. Since this specimen agrees as closely as any of them with the original description, I am selecting it as the lectotype.

G. heterophylla subsp. montana Carolin, subsp. nov.

[G. heterophylla subsp. 'C' Jacobs \& Pickard, Plants of N.S.W. 133 (1981)].

Herbae suffruticosae erectae scabridae pilis antrorsis simplicibus et partibus junioribus pubescentibus pilis multicellularibus.

Holotype: New South Wales: Mt Colong, E.F. Constable, 4 March 1948 (NSW 81462).

Differs from the type subspecies as follows: erect, suffruticose herb, villous to cottony indumentum with multicellular hairs and only very few glandular hairs when young, becoming scabrid with short antrorse simple hairs. Leaves linear to narrow-oblong, $1.5-2.5 \mathrm{~cm}$ long, $2-3 \mathrm{~mm}$ wide rarely more, entire or nearly so; margins revolute.

RANGE: Central and Southern Tablelands Districts of New South Wales.

HABITAT: Forests.

Selected Specimens (12): New South Wales: Big Hill Stn. Upper Burragorang Valley, E.F. Constable, 4 Oct. 1956 (NSW 42828); Yerranderie, R.H. Cambage 3131, 2 Dec. 
1911 (SYD, NSW 81469); Moss Vale, P. Snowden 235, 31 Oct. 1962 (NSW 81456, CANB 190035); Wingello S.F., E.F. Constable, 21 Jan. 1956 (NSW 35344); Bluebush Range to Kiaramba Ridge, L.A.S. Johnson, 28 March 1948 (NSW 5023); Tolwong turnoff Nerriga-Jervis Bay road, $R$. Pullen 2025, 8 Dec. 1959 (NSW 1407).

Named from its occurrence in the Central and Southern Tablelands of New South Wales. Latin, montanus $=$ montane.

G. rotundifolia $R$. Br., Prodr.: 576 (1810).

Lectotype: QueEnSLAND: Shoalwater Bay Passage, R. Brown, 26 Oct. 1802 (BM). Isolectotypes: K, MEL 23858, P. Paralectotype: Paterson River (East Coast), $R$. Brown (BM). Brown recognises two variations: $\alpha$ 'glaberrima' and $\beta$ 'pubescens'. There are two collections of $G$. rotundifolia by Brown in BM, one from the Paterson River, N.S.W., and the other the lectotype. The general description he gives covers both of them fairly adequately. However the specimen from Shoalwater Bay, which is glabrous, is labelled $G$. rotundifolia both on the sheet and in his notes and agrees closely with $\alpha$ 'glaberrima....... The Paterson River (East Coast) specimen however is referred to as ' $G$. crenata' in his notes. This later name was never used but the specimen is labelled ' $G$. rotundifolia' and agrees with the description of $\beta$ 'pubescens'. There seems little doubt that an element of $\alpha$ 'glaberrima' must be selected as a type despite its being glabrous an uncommon feature in the species.

\section{G. arenicola Carolin, sp. nov.}

Herbae stoloniferae vel rhizomatosae. Folia oblanceolata $4-10 \mathrm{~cm}$ longa pilis simplicibus glandulosisque parvissimis integra vel dentata in rosulis indistinctis disposita. Flores in axillis foliorum in pedunculis pubescentibus bracteolatis dispositi. Sepala lineari-deltoidea 5-6 mm longa. Corolla flava 15-17 mm longa pilis parvis extra atque enationibus intra. Ovarium attenuatum ad basim biloculatum fere ad summum. Indusium transverse oblongum $2 \mathrm{~mm}$ longum plicatum.

HolotyPe: QueENSLAND: Stradbroke Island, s.c., HT 13903, s.d. (NSW).

Branched, stoloniferous or rhizomatous herb. Leaves clustered at ends of short pubescent stems, oblanceolate, 4-10 $\mathrm{cm}$ long, $8-14 \mathrm{~mm}$ wide, tapering into a distinct petiole $2-4 \mathrm{~cm}$ long, entire or dentate, sparsely pubescent with minute simple and glandular hairs scattered over both surfaces. Flowers solitary in leaf axils, peduncles minutely pubescent, $3-4 \mathrm{~cm}$ long; pedicels $3-4 \mathrm{~cm}$ long; bracteoles linear, 4-6 $\mathrm{mm}$ long, $0.3 \mathrm{~mm}$ wide, pubescent. Sepals linear-deltoid, 5-6 mm long, acute, entire, pubescent, adnate to ovary to its summit. Corolla yellow, 15-17 mm long, pubescent outside with minute mostly simple hairs, minutely pubescent and with rows of enations inside, auriculate; anterior pocket very short and obscure, less than $1 / 2$ as long as ovary; tube $2.5-3 \mathrm{~mm}$ long; superior lobes falcate-oblanceolate, $10 \mathrm{~mm}$ long, $1.5-1.8 \mathrm{~mm}$ wide; inferior lobes ovate-oblong, 7-8 $\mathrm{mm}$ long, $2-2.5 \mathrm{~mm}$ wide; wings $2.5 \mathrm{~mm}$ wide; connate part of inferior lobes $6-7 \mathrm{~mm}$ long. Stamen filaments linear, $2-2.5 \mathrm{~mm}$ wide; anthers narrow-oblong, 1.8-2 mm long. Ovary tapering gradually to base, minutely pubescent; septum almost as long as loculus; ovules c. 30 ; style 5-6 $\mathrm{mm}$ long with a few scattered hairs; indusium transverse-oblong, $2 \mathrm{~mm}$ long, $2.5 \mathrm{~mm}$ wide, brownish, folded, glabrous above but pubescent beneath with a very curved orifice beset with minute white bristles c. $0.1 \mathrm{~mm}$ long. Fruit and seed not seen.

RANGE: Known only from the type collection.

HABITAT: Stabilized sand-dunes. 
Discussion: This species is clearly related to the $G$. hederacea group of species but very different from most of them. From other species with stoloniferous stems it differs in the minute soft indumentum and the very gradual taper to the base of the ovary.

Named for the habitat. Latin, aren $a=$ sand, - cola $=$ an inhabitant or a dweller.

G. hederacea subsp. alpestris (K. Krause) Carolin, comb. nov.

BAsionym: G. hederacea var. alpestris K. Krause, Pflanzenr. 54: 56 (1912).

LeCtotype: Victoria: Australian Alps, Mt Buller, F. Mueller (K). Paralectotypes: Hardinger Range, F. Mueller (B destroyed, P); Mt. St. Bernhard, Walter, Jan. 1899 (B destroyed); Harrietville, Mt St Bernhard, Weindorfer 66, Dec. 1902 (W); Mt Hotham, Weindorfer, Dec. 1902 (B destroyed); Mt Kosciusko, Kretschmann, Dec. 1892 (B destroyed).

G. hederacea var. cordifolia Ewart, Fl. Victoria: 1073 (1931) = G. hederacea subsp alpestris ( $K$. Krause) Carolin.

LECTOTYPE: Unfortunately no type for this variety has been located. Its identity is, however, not in doubt.

G. mooreana K. Krause, Pflanzenr. 54: 57 (1912) = G. xanthosperma F. Muell.

LeCtOTYPE: WeSteRn Australia: Coolgardie, Webster, s.d. (BM); ISOLECTOTYPE: B destroyed. ParalectotyPes: Coolgardie, Gnarlbine, S. Moore, Sept. 1895 (BM); sudliche von Coolgardie, Diels 5236, Oct. 1901 (B destroyed).

G. geniculata $R$. Br., Prodr.: 557 (1810).

LeCtotype: Victoria: Port Phillip, R. Brown, s.d. (BM). IsolectotyPes: K, P.*

G. lanata $R$. Br., Prodr.: 577 (1810).

Lectotype: Tasmania: Port Dalrymple, R. Brown, 5-6 Jan. 1804 (BM). Isolectotypes: K, MEL.*

G. goodeniacea (F. Muell.) Carolin, comb. nov.

BAsionym: Scaevola goodeniacea F. Muell., Fragm. 1: 121 (1859). (Catospermum goodeniaceum (F. Muell.) K. Krause). The original spelling of the generic name by Bentham in Hooker's Icones Plantarum tab. 1028 is 'Catospermum'; he subsequently altered this to 'Catosperma' in Flora Australiensis 4: 83 and $\mathrm{K}$. Krause also used this spelling. 'spermum', however, is an acceptable latinization and there is no reason to change the original spelling.

\section{G. convexa Carolin, sp. nov.}

Herba decumbens perennis. Folia obovata ad anguste obovata $3-12 \mathrm{~cm}$ longa dentata obtusa villosa utrinque pilis stellatis et multicellularibus in rosula pro parte maxima disposita. Flores in racemis foliosis pedunculis $1-6 \mathrm{~cm}$ longis. Bracteolae lineares vel anguste ovatae. Sepala anguste elliptica ad anguste oblonga 5-8 $\mathrm{mm}$ longa. Corolla flava $15-24 \mathrm{~mm}$ longa villosa extus sed sine enationibus intus. Capsula ovoideo-cylindrica $1-1.5 \mathrm{~cm}$ longa 4-valvulata.

Holotype: Western Australia: Swan River, J. Drummond 405 (K). Isotype: MEL 24318.

Decumbent usually perennial herb with short erect \pm branched stock, \pm hirsute with mostly stellate and multicellular hairs. Scapes terete, to $15 \mathrm{~cm}$ long. Leaves 
mostly ascending from stock, obovate to narrow-obovate, $3-12 \mathrm{~cm}$ long, 4-25 $\mathrm{mm}$ wide, narrowing very gradually towards base, dentate, with few simple hairs amongst others towards apex. Flowers in condensed or elongated racemes; bracts leaf-like; peduncles 1-6 cm long; bracteoles linear to narrow-ovate, 4-15 $\mathrm{mm}$ long, 1-3 mm wide; pedicel 3-5 mm long, often geniculate at bracteoles, not articulate. Sepals narrow-elliptic to narrow-oblong, 5-8 $\mathrm{mm}$ long, 0.5-2 $\mathrm{mm}$ wide, obtuse, pubescent with multicellular and stellate hairs the former yellowish and usually tangled together, adnate to ovary for $3 / 4$ its length. Corolla yellow, 15-24 mm long, villous-pubescent outside with stellate and multicellular hairs and with a few simple ones towards top, with few scattered hairs towards base inside but no enations, auriculate; anterior pouch obscure, $<1 / 2$ as long as ovary; tube 3-4 mm long; superior lobes narrow-oblong $12-15$ $\mathrm{mm}$ long, 1.5-2 $\mathrm{mm}$ wide; inferior lobes narrow-oblong, 8-15 mm long, 1.5-2 $\mathrm{mm}$ wide; wings c. $2 \mathrm{~mm}$ wide; connate part of inferior lobes $4-6 \mathrm{~mm}$ long. Stamen filaments linear, c. $3 \mathrm{~mm}$ long; anthers narrow-oblong, c. $1.5 \mathrm{~mm}$ long. Ovary villous; septum almost as long as loculus; ovules c. 30 ; style $3-4 \mathrm{~mm}$ long, slightly villous towards top; indusium transverse-oblong to transverseobovate, c. $3 \mathrm{~mm}$ long, $2-2.5 \mathrm{~mm}$ wide, slightly folded, villous, with a very convex orifice beset with white bristles c. $0.2 \mathrm{~mm}$ long. Fruit ovoid to cylindrical, $1-1.5 \mathrm{~cm}$ long, c. $6 \mathrm{~mm}$ wide, 4-valved but scarcely separating below level of sepals. Seeds flat, pale brown, elliptic, 1.8-2.5 $\mathrm{mm}$ long, smooth, with a distinct rim; wing 1.2-1.5 $\mathrm{mm}$ wide, mucilaginous.

RANGE: Avon District of Western Australia

HABITAT: Heath and open forests on sandy soils.

Chromosome Number: $n=8$ (Peacock 1963, as $G$. affinis).

Discussion: This species has previously been included in $G$. affinis and differs from it in the very convex lips of the indusium, the looser coarser simple hairs, and a tendency to form almost stoloniferous scapes. It also shows some similarities to $G$. robusta but its bracts and cauline leaves are never stem-clasping as in that species.

Specimens EXamined (10): Western Australia: Jurien Bay road, W.E. Blackall 3658 , 29 Aug. 1938 (PERTH); Youndegin, C.A. Gardner 7483, 19 Oct. 1944 (PERTH); Taylors Well near Pingelly, R.C. Carolin 3166, 18 Aug. 1961 (SYD); 21 miles (33.6 km) W of Coorow, C.H. Gittins 1675, Sept. 1967 (NSW).

Named for the very convex orifice of the indusium. Latin, convexus $=$ convex.

\section{G. tripartita Carolin, sp. nov.}

Herba decumbens vel prostrata. Scapi usque $15 \mathrm{~cm}$ longi. Folia basalia anguste elliptica vel late elliptica vel obovata $4-7 \mathrm{~cm}$ longa $1-2 \mathrm{~cm}$ lata crenato-dentata albide villosa pilis stellatis et multicellularibus versus basim in petiolum contracta. Flores in pedunculis bibracteolatis. Corolla flava c. $18 \mathrm{~mm}$ longa gossypine villosa extus sine enationibus intus. Indusium 3-fidum ramo medio late obovato et ramo laterali curvo-lineari plicato. Capsula 2-valvulata sed non ad basim. Semina plana flava laevia elliptica $2 \mathrm{~mm}$ longa ala indistinctissima.

Holotype: WeStern Australia: Ongerup-Ravensthorpe, Fitzgerald River, R.C. Carolin 3569, 11 Sept. 1961 (NSW).

Decumbent to prostrate perennial herb with a strong taproot and stock, cottony-villous with stellate and multicellular hairs the latter often tangled together. Scapes terete, to $15 \mathrm{~cm}$ long. Leaves mostly basal, narrow-elliptic to broad-elliptic or obovate, $4-7 \mathrm{~cm}$ long, 1-2 $\mathrm{cm}$ wide, narrowing often abruptly 
into a \pm distinct petiole, crenate-dentate, sometimes slightly crisped. Flowers in racemes; bracts leaf-like but smaller; peduncles $1-3 \mathrm{~cm}$ long; bracteoles linear, c. $4 \mathrm{~mm}$ long, $1 \mathrm{~mm}$ wide, often obscured by hairs; pedicels $1-2 \mathrm{~cm}$ long, geniculate at bracteoles, not articulate. Sepals linear, 4-5 $\mathrm{mm}$ long, $1 \mathrm{~mm}$ wide, \pm obtuse, adnate to ovary almost to its summit. Corolla bright yellow, c. $18 \mathrm{~mm}$ long, villous outside with stellate multicellular and a few simple hairs, sprinkled with a few hairs but without enations inside, auriculate; anterior pocket less than $1 / 2$ as long as ovary; tube 1.5-2 $\mathrm{mm}$ long; superior lobes narrow-obovate to narrow-elliptic, \pm falcate, c. $11 \mathrm{~mm}$ long, $2.5 \mathrm{~mm}$ wide; inferior lobes oblongelliptic, $8-9 \mathrm{~mm}$ long, $2.5-3 \mathrm{~mm}$ wide; wings c. $2.5 \mathrm{~mm}$ wide; connate part of inferior lobes 5-6 mm long. Stamen filaments $3 \mathrm{~mm}$ long; anthers narrowoblong, $2 \mathrm{~mm}$ long. Ovary septum almost as long as loculus; ovules 30-32; style $4 \mathrm{~mm}$ long, glabrous; indusium 3-fid; median branch broad-ovate, $1 \mathrm{~mm}$ long, $2.5 \mathrm{~mm}$ wide, yellow-brown, with few villous hairs, folded in front of the median branch, with a curved orifice beset with bristles c. $0.1 \mathrm{~mm}$ long or lips glabrous; side-branches curved-linear, c. $1 \mathrm{~mm}$ long, surmounted by a tuft of white bristles. Fruit ovoid, c. $13 \mathrm{~mm}$ long, c. $7 \mathrm{~mm}$ wide, 2-valved but usually only to midway, each valve bifid. Seed flat, yellow, elliptic, c. $2 \mathrm{~mm}$ long, smooth, with a distinct rim; wing almost obsolete.

RANGE: Esperance district of Western Australia.

HABITAT: Sandy soils

Chromosome Number: $n=8$ (Peacock 1963, as G. affinis).

Discussion: Previously included in G. affinis, this species can be distinguished by its 3-partite indusium.

SPECIMENS EXAMINed (39): WeStern Australia: Marchagee, F. Vanzetti, Oct. 1925 (PERTH); Waddouring, W.B. Alexander 1242, Oct. 1915 (PERTH); 1 mile (1.6 km) E of Boorabbin, C.A. Gardner, 20 Oct. 1945 (PERTH); 2 miles $(3.2 \mathrm{~km})$ from Dowerin towards Wyalkatchem, M.E. Phillips, 19 Sept. 1962 (CBG 019012, SYD); between Pingrup and Lake Grace, W.E. Blackall 3054, 21 Sept. 1933 (PERTH); Nyabing, R.H. Kuchel 1881, 17 Sept. 1964 (AD 96531152); 1 mile (1.6 km) S of Borden, F. Lullfitz L3363, 16 Aug. 1964 (PERTH).

The specific epithet refers to the indusium, which is divided into three distinct parts, two curved linear lateral lobes and a broad-ovate central part. Latin, tri$=$ three, partitus $=$ partite.

\section{G. willisiana Carolin, sp. nov.}

Herba erecta vel ascendens villosa pilis stellatis et multicellularibus caulorrhiza erecta ramosa et scapis brevis. Folia basalia anguste elliptica vel anguste obovata, 4-9 cm longa, 4-18 $\mathrm{mm}$ lata. Corolla flava c. $15 \mathrm{~mm}$ longa villosa extus glabra et sine enationibus intus. Septum ovarii tres partes longitudinem loculi. Indusium transverse ellipticum $1.5 \mathrm{~mm}$ longum $2.5 \mathrm{~mm}$ latum plicatum. Capsula 2-valvulata. Semina plana flava laevia elliptica $2 \mathrm{~mm}$ longa, ala brevissima.

HoLOTYPE: Redcliffs, NW Victoria, J.H. Willis, Aug. 1940 (MEL 24304). There are three specimens mounted on the same sheet. 'Wimmera, $C$. Walter' without date, and 'Redcliffs, J.H. Willis, Aug. 1937' are herewith excluded from the type. The holotype consists only of the remaining specimen from Redcliffs.

Erect or ascending herb with thick taproot and usually a well-developed stock, covered with villous stellate and multicellular hairs the latter tangled around each other. Scapes terete, usually shorter than leaves. Leaves basal, narrowelliptic to narrow-oblong or lanceolate, 4-9 $\mathrm{cm}$ long, 4-18 $\mathrm{mm}$ wide, narrowing 
very gradually towards base, obtuse or acute, entire or irregularly dentate; cauline leaves if present never stem-clasping. Flowers apparently solitary in axils of basal leaves; peduncles to $5 \mathrm{~cm}$ long; bracteoles linear, c. $2 \mathrm{~mm}$ long, almost obscured by hairs; pedicels to $4 \mathrm{~mm}$ long, geniculate at bracteoles, not articulate. Sepals narrow-oblong, $3.5 \mathrm{~mm}$ long, $0.5 \mathrm{~mm}$ wide, acute, adnate to ovary nearly to its top. Corolla yellow, $15 \mathrm{~mm}$ long, villous-pubescent outside with stellate and multicellular hairs only very rarely with a few simple hairs towards top, glabrous or nearly so and without enations inside, auriculate; anterior pocket $<1 / 2$ as long as ovary; tube $2-3 \mathrm{~mm}$ long; superior lobes narrowobovate-elliptic, 8-9 mm long, 1.5-1.8 mm wide; inferior lobes oblong-elliptic, $5-6 \mathrm{~mm}$ long, c. $1.5 \mathrm{~mm}$ wide; wings c. $2.5 \mathrm{~mm}$ wide; connate part of inferior lobes 4-6 mm long. Stamen filaments linear, c. $2 \mathrm{~mm}$ long; anthers narrowoblong, c. $1.5 \mathrm{~mm}$ long. Ovary septum $3 / 4$ as long as loculus; ovules $28-30$; style $3.5 \mathrm{~mm}$ long, glabrous, scarcely geniculate; indusium transverse-elliptic, 1.5 $\mathrm{mm}$ long, $2.5 \mathrm{~mm}$ wide, folded, glabrous on back, with few villous hairs on front, with a curved orifice beset with white bristles to $0.2 \mathrm{~mm}$ long on both lips. Fruit ovoid-ellipsoid, c. $1 \mathrm{~cm}$ long, 4-5 mm wide, 4-valved to midway or 2 -valved to base with each valve bifid. Seeds flat, yellow, elliptic, $2 \mathrm{~mm}$ long, smooth, with a distinct rim; wing c. $0.1 \mathrm{~mm}$ wide.

RANGE: Southern part of South Australia, western Victoria and the Riverina district of New South Wales.

HABITAT: Mallee and open forest in dry communities.

Discussion: This species has been referred to $G$. affinis in the past. The species related to $G$. affinis are listed below together with the main features distinguishing them.

G. affinis. Indusium with a shallowly concave upper lip; bristles short. Indumentum villous. Cauline leaves not stem-clasping.

G. willisiana. Indusium with a straight to slightly convex orifice; bristles long. Indumentum villous. Cauline leaves not stem-clasping.

$G$. convexa. Indusium with a very convex orifice; bristles long. Indumentum hirsute, tangled. Cauline leaves not stem-clasping.

G. tripartita. Indusium 3-lobed; bristles long on lateral lobes. Indumentum villous. Cauline leaves not stem-clasping.

$G$. robusta. Indusium with a very convex orifice; bristles short. Indumentum villous. Cauline leaves stem-clasping.

Specimens Examined (87): South Australia: N of Caroline Bluff, Mt. Gambier, J.B. Cleland, 9 Nov. 1955 (AD 96720010); 10 miles (16 km) W of Minnipa, H.W. Caulfield 31, 21 Sept. 1955 (AD 96213166); Pinkawillinie, R.D. Rohrlach 189, 1 March 1959 (AD 95924013). Victoria: Nhill-Murrayville, J.J. Ackland 79, 1 Oct. 1963 (MEL 24305); Dimboola, D. Kraehenbuehl 35, 11 Oct. 1958 (AD 96422050). NEW SOUTH WaLES: Rankins Springs road, G. Althofer 8A, 1966 (NSW).

Named for J.H. Willis, formerly of the National Herbarium of Victoria, who collected the type specimen.

G. geniculata var. robusta Benth., Fl. Austral. 4: $63(1868)=$ G. robusta (Benth.) K. Krause, Pflanzenr. 54: 53 (1912).

Lectotype: South AuSTRalia: Marble Range, Wilhelmi, s.d. (K). Isolectotype: MEL, P. ParalectotyPes: Wimmera, Dallachy (MEL); Lake Koorong, Herb. Muell. (MEL); Marble Range, Wilhelmi (K, MEL, P). 
G. glabra $R$. Br., Prodr.: 577 (1810).

Lectotype: South Australia: Port 1, R. Brown, s.d. (BM). Isolectotype: K.*

G. gracilis $R$. Br., Prodr.: 575 (1810).

Lectotype: Queensland: Broad Sound, R. Brown, 15 Sept. 1802 (BM). Isolectoype: $\mathrm{K} . *$

G. rosulata Domin, Biblioth. Bot. 22: 1198 (1929) = G. paniculata Sm.

LECTOTYPE: QUEENSLAND: Aperti loci arenosi in xerodrymio ad opp. Jericho, Domin 8783, March 1910 (PR 531399).

\section{G. macbarronii Carolin, sp. nov.}

Herba plus minusve annua. Folia basalia anguste obovata usque linearilanceolata $5-11 \mathrm{~cm}$ longa glabra crassa dentibus paucis. Flores in racemis vel thyrsis erectis dispositi. Bracteae lineares. Pedunculi glabri usque $25 \mathrm{~mm}$ longi bracteolis triangularibus. Corolla flava $7-9 \mathrm{~mm}$ longa pubescentia extus. Lobi superiores corollae auriculati. Capsula subglobosa $3-4 \mathrm{~mm}$ longa duabus valvis dehiscens. Semina nitida biconvexa orbicularia $0.5 \mathrm{~mm}$ diametro.

Holotype: New South Wales: Holbrook, E.J. McBarron 647, 10 Feb. 1947 (NSW). ISOTYPE: SYD.

Annual or short-lived erect perennial herb with a short stock, with welldeveloped secondary root system and sometimes a thickish tap root. Scapes terete or slightly angled when young, to $30 \mathrm{~cm}$, glabrous. Leaves thick, mostly basal, narrow-obovate to linear-oblanceolate, $5-11 \mathrm{~cm}$ long, 2-6 mm wide, narrowing very gradually into an indistinct petiole with a broadened scariose base, acute, with a few coarse teeth on margin, glabrous. Flowers in erect terminal thyrses or racemes; bracts linear, 2-20 mm long, $0.5-1 \mathrm{~mm}$ long; bracteoles triangular, $1-1.5 \mathrm{~mm}$ long, $0.3-0.5 \mathrm{~mm}$ wide, acute, glabrous or with a few mostly simple hairs; pedicel $0.5-3 \mathrm{~mm}$ long, simple-pubescent or glabrous below but mostly glandular-pubescent above articulate c. $0.5 \mathrm{~mm}$ below ovary. Sepals linear to elliptic, 1-2 mm long, $0.2-0.5 \mathrm{~mm}$ wide, glandular-pubescent with few simple hairs, acute, entire, adnate to ovary for $3 / 4$ its length. Corolla yellow, 7-9 $\mathrm{mm}$ long, glandular-pubescent with a few simple hairs outside, sprinkled with simple and glandular hairs, with very few obscure enations inside, auriculate; anterior pouch obscure; tube 2-2.5 mm long; superior lobes oblanceolate, c. $5 \mathrm{~mm}$ long, $1 \mathrm{~mm}$ wide; inferior lobes oblong-elliptic, 4-4.5 $\mathrm{mm}$ long, $1 \mathrm{~mm}$ wide; wings $1-1.2 \mathrm{~mm}$ wide; connate part of inferior lobes c. $2 \mathrm{~mm}$ long. Stamen filaments linear, $1.5 \mathrm{~mm}$ long; anthers narrow-oblong c. $1 \mathrm{~mm}$ long, c. $0.3 \mathrm{~mm}$ wide, apiculate. Ovary glandular-pubescent, with few simple hairs; septum $3 / 4$ as long as loculus; ovules numerous, scattered on placentas; style $5 \mathrm{~mm}$ long, villous-pubescent; indusium square, $1 \mathrm{~mm}$ long, brown sometimes tinged with purple, not folded but sometimes slightly notched, with a straight orifice beset with white bristles c. $0.1 \mathrm{~mm}$ long on upper lip and somewhat shorter ones on lower lip. Fruit subglobular to ovoid, 3-4 mm long, c. $2 \mathrm{~mm}$ wide, glandular and simple-pubescent, 2-valved almost to base, each valve entire. Seeds biconvex, yellow-brown, orbicular, $0.5 \mathrm{~mm}$ diam., reticulate-foveate, shining; wing $<0.1 \mathrm{~mm}$ wide, mucilaginous.

RANGE: North East Victoria; Western Plains, Western Slopes and Tablelands in New South Wales and Darling Downs in Queensland.

HABITAT: Damp places.

Chromosome Number: $n=8$ (Peacock 1963, as G. gracilis Sm). 
Discussion: This has previously been confused with $G$. gracilis, from which it differs in the indusium which is not folded, and with $G$. paniculata, from which it differs in the thicker narrower leaves, the smaller square indusium which is never altogether purple, the smaller flowers and the chromosome number. The specimens from Victoria tend to have rather larger flowers but otherwise agree fairly well with those from north of the Murray River.

Selected SPECIMENS (25): Victoria: Ovens River, F. Mueller, 9 Feb. 1853 (MEL 23419). New South WALES: Maryland, E. Hickey, Jan. 1885 (MEL 23338); Tingha, J.L. Boorman, March 1917 (NSW 81554); Chandlers Peak Guyra, J.L. Boorman, March 1917 (NSW 81556); Warrumbungle Ranges, E. Betche 60, Jan. 1883 (MEL 23352); 15 miles $(24 \mathrm{~km}) \mathrm{E}$ of Rylestone, H.S. McKee 444, 10 Jan. 1953 (SYD). QuEENSLAND: Fletcher, Stanthorpe district, W.J.F. McDonald 1758, 31 Jan. 1977 (BRI 221919).

Named for the collector of the holotype, an avid collector, who was a veterinarian in the New South Wales Department of Agriculture.

G. lamprosperma $F$. Muell., Fragm. 1: 116 (1859).

LECTOTYPE: NORTHERN TERRITORY: Upper Victoria River, F. Mueller, Dec. 1855 (MEL 23395). ISOLECTOTYPE: K. Paralectotype: Near McAdams Range, F. Mueller, Dec. 1855 (MEL 23396).

G. humilis $R$. Br., Prodr.: 575 (1810).

Lectotype: Victoria: Arthur's Seat, Port Phillip, R. Brown, 25 Jan. 1804 (BM). ISOLECTOTYPES: $\mathrm{K}$, MEL, P.*

G. propinqua W. Fitzg., J. \& Proc. Roy. Soc. Western Australia 3: 213 (1918)= G. bicolor F. Muell.

LECTOTYPE: WeStern AUSTRALIA: Inglis Gap, King Leopold Ranges, W.V. Fitzgerald, s.d. (NSW). PARALECTOTYPES: Bold Bluff, Isdell River, W.V. Fitzgerald (NSW).

\section{G. gloeophylla Carolin, sp. nov.}

Herba erecta suffruticosa viscidula ad $50 \mathrm{~cm}$ alta. Folia caulina linearia ad anguste elliptica $4-8 \mathrm{~cm}$ longa anguste dentata plus minusve sessilia. Flores in racemis vel thyrsis terminalibus dispositi. Pedunculi bracteolati viscidula. Pedicelli articulati. Sepala anguste deltoidea $1-1.5 \mathrm{~mm}$ longa pilis glandulosis. Corolla lilacina vel violacea $10-12 \mathrm{~mm}$ longa pilis glandulosis extra. Ovulae in placentis irregulariter dispositae.

Holotype: Western Australia: Longini Landing, Kalumburu Mission, D.E. Symon 7125, 29 May 1971 (ADW 41918). IsOTYPES: CANB, PERTH, SYD.

Erect branched glandular-pubescent and viscid suffruticose herb. Leaves scattered along stems, linear to very narrow-elliptic, $4-8 \mathrm{~cm}$ long, 1-2.5 mm wide, tapering very gradually to a blunt tip and towards base into an indistinct petiole, dentate with narrow teeth, with very short villous axillary hairs. Flowers in terminal racemes or thyrses; bracts leaf-like but narrower and shorter and never exceeding flower; peduncles to $18 \mathrm{~mm}$ long; bracteoles linear, 3-8 $\mathrm{mm}$ long, acute, entire, often not exactly opposite; pedicels $2-4 \mathrm{~mm}$ long, articulate 1-2 mm below ovary. Sepals narrow-deltoid, 1-1.5 mm long, 0.3-0.5 mm wide, acute, entire, adnate to ovary almost to its summit. Corolla pale to deep purple, 10-12 mm long, glandular-pubescent outside, with few long simple hairs inside, indistinctly auriculate; anterior pocket prominent and half as long as or equal to ovary; tube 3-4 $\mathrm{mm}$ long; superior lobes narrow-oblong-elliptic, 6-6.5 $\mathrm{mm}$ long, $0.8-1.2 \mathrm{~mm}$ long; inferior lobes narrow-oblong-elliptic, 5-6 mm long, 0.8-1.2 mm wide; wings c. $1 \mathrm{~mm}$ wide. Stamen filaments linear, c. $3 \mathrm{~mm}$ long; 
anthers narrow-oblong, $1.5 \mathrm{~mm}$ long, $0.3-0.5 \mathrm{~mm}$ wide. Ovary glandularpubescent; septum almost as long as loculus; ovules c. 20 in two \pm irregular rows; style 4-5 mm long, glabrous; indusium broad-ovate-oblong, $1.5 \mathrm{~mm}$ long, $1 \mathrm{~mm}$ wide, purple, folded, with few long white hairs on both surfaces towards base, with a straight orifice beset with bristles to $0.1 \mathrm{~mm}$ long. Fruit cylindrical to ovoid, $8-10 \mathrm{~mm}$ long, $3 \mathrm{~mm}$ wide, 2-valved. Seed biconvex, brown, elliptic, $1.5 \mathrm{~mm}$ long, reticulate-foveate, glossy with a distinct rim; wing c. $0.1 \mathrm{~mm}$ wide.

RANGE: Gardner (Kimberley) Region of Western Australia and Darwin-Gulf Region of Northern Territory.

HABITAT: Heaths and shrublands on poor sandy soils.

Discussion: This species is tentatively placed in section Porphyranthus on the basis of the irregular ovule insertion, and the seed ornamentation, the folded indusium with shortish bristles and the pedicel articulation. The suffruticose habit is unknown in the rest of that section.

Specimens EXamined: Western Australia: (see holotype). NORTHERn Territory: 2-3 miles (3.2-4.8 km) N of El Sharana, Martensz \& Schodde AE 565 (NT 38842); Waterfall Creek 1 mile $\left(1.6 \mathrm{~km}\right.$ ) above falls (South Alligator), N. Byrnes NB1518 (NT 14994); $13^{\circ}$ 03'S 132 56'E, M. Lazarides 8011, 4 April 1973 (CANB 239891); 41 miles $(65.6 \mathrm{~km}$ ) from Pine Creek to U.D.P. Falls, C.H. Gittins 2846, 1 May 1975 (SYD, BRI).

Named for the viscid leaves. Greek, gloeus = sticky, phyllon = leaf.

G. purpurascens $R$. Br., Prodr.: 578 (1810).

LeCtotyPe: Northern Territory: Bay No. 3, Point 2, (i.e. Arnhem Bay), R. Brown, 3 March 1903 (BM).\# Brown made two collections of this species, describing both collections in his field notes. In the Prodromus he describes this species as 'foliis radicalibus elongato-lanceolatis' but in his field notes only the specimens from Arnhem Bay are described as having lanceolate leaves. The Arnhem Bay specimens agree with this description whilst the other collection, from Groote Island, has linear leaves and Brown describes them as such in his field notes. The Arnhem Bay collection is therefore selected as the lectotype.

\section{G. minutiflora F. Muell., Fragm. 8: 224 (1874).}

LECTOTYPE: QUEENSLAND: Between the Norman and Gilbert Rivers, T. Gulliver 68 (MEL 23997). ISOLECTOTYPES: MEL 23998, 22243.*

\section{G. viscidula Carolin, sp. nov.}

Herba annua adscendens ad $25 \mathrm{~cm}$ alta radicibus fibrosis. Folia spathulata 4-11 $\mathrm{cm}$ longa pubescentia viscidula pilis simplicibus ac glandulosis brevis integra vel dentis paucis parvis in rosula erecta vel adscendenti disposita. Flores in thyrsis vel cymo-paniculis dispositi. Pedicelli et pedunculi viscidula pilis simplicibus brevis et glandulosis capitate brunne vel fulve. Corolla lilacina 5-7 $\mathrm{mm}$ longa pilis brevis patentibus extra. Ovulae numerosae in placentis dispersae. Capsula subglobosa vel ovoidea c. $1.5 \mathrm{~mm}$ in diametro. Semina biconvexa elliptica c. $0.3 \mathrm{~mm}$ longa nitida.

HOLOTYPE: NORTHERN TERRITORY: 166 miles from Borroloola on Daly Waters road, R.C. Carolin 9339, 19 May 1974 (NSW). IsOTYPE: SYD.

Erect to ascending viscid annual herb to $25 \mathrm{~cm}$ high, covered with simple and somewhat more numerous shortly stalked yellowish or brownish tipped glandular hairs, with a short stock and an adventitous root system. Leaves mostly basal, spathulate in overall shape but with a rather more distinct petiole than in 
other members of sect. Porphyranthus, (4-) 6-11 cm in overall length; lamina elliptic. $2-4 \mathrm{~cm}$ long, $10-20 \mathrm{~mm}$ wide, entire or obscurely toothed and sometimes with two narrow lobes near the base, usually acute. Cauline leaves similar but smaller. Flowers arranged in loose thyrses or cymo-panicles; bracts linear, c. $1 \mathrm{~mm}$ long; bracteoles linear, to $5 \mathrm{~mm}$ long, acute; often not exactly opposite; pedicels (6-) 9-11 mm long, articulate c. $0.5 \mathrm{~mm}$ below ovary. Sepals narrowovate-elliptic, $1 \mathrm{~mm}$ long, $0.3 \mathrm{~mm}$ wide, acute, adnate to ovary for $2 / 3$ its length. Corolla bluish purple, 5-7 $\mathrm{mm}$ long, pubescent with short soft patent simple hairs outside, with a few scattered hairs inside, indistinctly auriculate; anterior pocket scarcely $1 / 4$ as long as ovary; tube $2-3 \mathrm{~mm}$ long, curved; superior lobes narrow-oblong to oblanceolate, $3 \mathrm{~mm}$ long, $0.8 \mathrm{~mm}$ wide; inferior lobes ovate, $2 \mathrm{~mm}$ long, $0.8 \mathrm{~mm}$ wide; wings c. $1 \mathrm{~mm}$ wide; connate part of inferior lobes 2-3 mm long. Stamen filaments linear, $2 \mathrm{~mm}$ long; anthers narrow-oblong, 1 $\mathrm{mm}$ long. Ovary pubescent as outside of corolla; septum almost as long as loculus; ovules numerous, minute, scattered over both surfaces of septum; style $2.5 \mathrm{~mm}$ long, purple, villous; indusium square to oblong, c. $1 \mathrm{~mm}$ long, purple, not folded, with a straight orifice beset with short $(0.1 \mathrm{~mm})$ white bristles on upper lip, lower lip almost glabrous. Fruit subglobular to ovoid, c. $1.5 \mathrm{~mm}$ diam., pubescent, 2-valved often scarcely to midway very rarely to base, entire. Seeds biconvex, elliptic, c. $0.3 \mathrm{~mm}$ long, brownish, glossy, smooth to reticulate, with obscure rim; wing, narrow, mucilaginous.

RANGE: Burke District in Queensland and Darwin-Gulf District in Northern Territory.

Habitat: Seasonally damp sites especially in Melaleuca and Eucalyptus microtheca woodland.

Discussion: This species is distinguished from the other species grouped around $G$. purpurascens by the pubescent, viscid, \pm distinctly petiolate leaves. The flowers are somewhat larger than those of $G$. paludicola and $G$. minutiflora.

Selected Specimens (6): Northern Territory: Camp-Oven Waterhole, R.C. Carolin 9167, 9 May 1974 (SYD); 14 miles $(22.4 \mathrm{~km}) \mathrm{NW}$ of Corinda on road to Westmoreland, R.C. Carolin 9146, 7 May 1974 (SYD); Edith Falls, R.A. Perry 1941, 28 Aug. 1948 (BRI 015293).

Named for the viscid nature of the whole plant. Latin viscidulus = somewhat sticky.

\section{G. paludicola Carolin, sp. nov.}

Herba annua gracilis adscendens ad $25 \mathrm{~cm}$ radicibus fibrosis. Folia basalia adscendentis vel erecta lanceolata $4-7 \mathrm{~cm}$ longa glabra integra vel dentibus paucis parvis. Flores in thyrsis vel cymo-paniculis decompositis dispositi. Pedicelli et pedunculi pilis simplicibus patentis et pilis glandulosis capitatis nigris vel fuscis obtecti. Corolla lilacina $4-12 \mathrm{~mm}$ longa pilis simplicibus ac glandulosis extra. Ovulae numerosae in placentis dispersae. Capsula subglobosa $1.2-2.5 \mathrm{~mm}$ in diametro. Semina nitida fulva biconvexa elliptica $0.3-0.4 \mathrm{~mm}$ longa.

HolotYPE: QueENSLAND: 14 miles $(22.4 \mathrm{~km}) \mathrm{NW}$ of Corinda on road to Westmoreland, R.C. Carolin 9147, 7 May 1974 (NSW). ISOTYPE: SYD.

Slender ascending annual herb to $25 \mathrm{~cm}$, with a weak stock and mostly adventitious roots. Scapes numerous in axils of basal leaves, almost glabrous near base. Leaves almost all basal, ascending or erect, lanceolate, 4-7 cm long, 2-4 $\mathrm{mm}$ wide, tapering very gradually towards base into a very indistinct petiole, 
acute, entire or with few very obscure teeth, glabrous. Flowers arranged in much-branched thyres or cymo-panicles; bracts leaf-like but smaller and somewhat pubescent; peduncles to $3 \mathrm{~mm}$ long, pubescent with patent simple hairs and long black or very dark brown-tipped glandular hairs; bracteoles linear, 3-5 $\mathrm{mm}$ long, pubescent as peduncles, acute, not always exactly opposite; pedicels $7-9 \mathrm{~mm}$ long, pubescent as peduncles, articulate c. $0.5 \mathrm{~mm}$ below ovary. Sepals ovate to lanceolate $1.5-1.8 \mathrm{~mm}$ long, $0.5 \mathrm{~mm}$ wide, simple- and glandularpubescent, acute, adnate to ovary for $2 / 3$ its length. Corolla bluish purple, $4-5$ (12) $\mathrm{mm}$ long, simple- and glandular-pubescent outside, with very few scattered simple hairs inside, auriculate; anterior pouch almost obsolete; tube $2-3 \mathrm{~mm}$ long; superior lobes narrow-oblong, 2-3 mm long, $0.5 \mathrm{~mm}$ wide; inferior lobes ovate to narrow-ovate, $1.2 \mathrm{~mm}$ long, $0.5 \mathrm{~mm}$ wide; wings c. $1 \mathrm{~mm}$ wide, \pm as long as lobes; connate part of inferior lobes $1.5 \mathrm{~mm}$ long. Stamen filaments linear, $1.5 \mathrm{~mm}$ long; anthers oblong, $0.5 \mathrm{~mm}$ long. Ovary glandular- and simplepubescent; septum almost as long as loculus; ovules numerous, scattered over both surfaces of septum; style $4 \mathrm{~mm}$ long, slightly pubescent especially towards top; indusium \pm square but widening a little towards top, $0.5 \mathrm{~mm}$ long, purplish, glabrous, with an almost straight orifice beset with white bristles c. 0.2 $\mathrm{mm}$ long on upper lip but almost glabrous on lower lip. Fruit subglobular, 1.5-2.5 mm diam., simple- and glandular-pubescent, 2-valved to below midway but seldom to base, each valve entire. Seeds biconvex, yellowish, elliptic, $0.3-0.4 \mathrm{~mm}$ long, smooth, glossy, with an obscure rim; wing c. $0.1 \mathrm{~mm}$ wide, mucilagenous.

RANGE: Burke District in Queensland and northern part of Northern Territory.

HABITAT: Seasonally moist places, particularly in Melaleuca woodlands, but not on the heavier soils.

Discussion: This species is rather similar to $G$. minutiflora but the corolla is larger and deeper in colour and the auricles on the superior lobes enclose the indusium.

SPecimens EXamined: QueEnSLAND: 4 miles $(6.4 \mathrm{~km}) \mathrm{N}$. of Maggieville on Myravale road, R.C. Carolin 8766, 20 May 1974 (SYD). NORTHERn TERrITORY: Tin Camp Creek c. 20 miles $(24 \mathrm{~km}) \mathrm{S}$ of Nabarlek, T.G. Hartley 13775 (NT 44774); Katherine Gorge, C.L.Gunn 14 (NT 44320); Ferguson River, M. Parker 112 (NT 41718).

Named after the swampy conditions in which this species grows in the wet season. Latin, palus, paludis $=$ swamp, - cola $=$ a dweller.

\section{G. berringbinensis Carolin, sp. nov.}

Herba ad $30 \mathrm{~cm}$ scapis villosis. Folia basilia oblanceolata ad fere spathulata $3.5-6 \mathrm{~cm}$ longa villoso-pubescentia saepe glabrescentia. Flores in thyrsis laxis terminalis dispositi. Pedunculi 5-30 mm longi bracteolis lineari-ellipticis 4-15 $\mathrm{mm}$ longis. Pedicelli articulati $13-20 \mathrm{~mm}$ longi. Corolla flava villoso-pubescens extus. Ovulis numerosis in placentis dispersis. Capsula cylindrica 7-8 $\mathrm{mm}$ longa villosa-pubescens bivalvularis sepalis longitudine $1 / 2$ partes adnatis. Semina numerosa parva nitidula $0.8 \mathrm{~mm}$ longa.

Holotype: Western Australia: Bed of Berringbine Creek, Belele Station, C.A. Gardner 7857, 15 Oct. 1945 (PERTH).

Villous and minutely glandular herb with a short usually branched stock, with thin tap root and a well-developed adventitous root system. Scapes terete, ascending to $30 \mathrm{~cm}$. Leaves mostly basal, spreading or ascending, oblanceolate to almost spathulate, $3.5-6 \mathrm{~cm}$ long, $2-10 \mathrm{~mm}$ wide, tapering gradually into a 
distinct petiole to $3 \mathrm{~cm}$ long with broad scarious base, obtuse, entire or with few blunt teeth, villous-pubescent, often \pm glabrescent. Flowers in loose spreading terminal thyrses; bracts linear to elliptic, 4-15 mm long, 1-2 mm wide, entire; peduncles 5-30 mm long; bracteoles sometimes not exactly opposite, linear-elliptic, 3-4 mm long; pedicels $13-20 \mathrm{~mm}$ long, articulate c. $1 \mathrm{~mm}$ below ovary. Sepals lanceolate-elliptic, c. $3 \mathrm{~mm}$ long, $0.5 \mathrm{~mm}$ wide, adnate to ovary for $1 / 2-3 / 4$ its length. Corolla yellow with purplish auricles, c. $12 \mathrm{~mm}$ long, villous-pubescent with long simple and minute glandular hairs outside, with some scattered simple hairs inside, auriculate; anterior pocket not prominent, \pm as long as ovary; tube c. $3 \mathrm{~mm}$ long; superior lobes narrow-oblong, $8 \mathrm{~mm}$ long, $0.8 \mathrm{~mm}$ wide; inferior lobes oblong, $4-5 \mathrm{~mm}$ long, $0.8 \mathrm{~mm}$ wide; wings to $2 \mathrm{~mm}$ wide; connate part of inferior lobes $5-6 \mathrm{~mm}$ long. Stamen filaments c. $3.5 \mathrm{~mm}$ long; anthers narrow-oblong, $1.5 \mathrm{~mm}$ long. Ovary villous-pubescent; septum $2 / 3$ as long as loculus; style $7-8 \mathrm{~mm}$ long; indusium obtriangular, truncate at base, c. $1.5 \mathrm{~mm}$ long, $2 \mathrm{~mm}$ wide, convex, with an almost straight orifice beset with white bristles $0.3 \mathrm{~mm}$ long. Fruit ellipsoid to cylindrical, 7-8 mm long, prominently beaked (i.e. sepals attached about halfway), 2 -valved to base, each valve entire. Seeds flat to biconvex, yellow-brown, elliptic, $0.8 \mathrm{~mm}$ long, smooth, glossy; wing c. $0.1 \mathrm{~mm}$ wide, mucilaginous.

RANGE: Known from the type collection only, north west of Meekatharra.

HABITAT: Red sandy loam.

Discussion: The attachment of the sepals low down on the elongated capsule is characteristic of this species.

Named for the locality of the type collection.

\section{G. lyrata Carolin, sp. nov.}

Herba caulis prostratis usque $13 \mathrm{~cm}$ longis fere glabris sed pilis perpaucis minutis versus apicem et fasciculis pilorum villosorum in axillis instructis. Folia lyrata oblanceolata $7-28 \mathrm{~mm}$ longa crassa pubescentia molliter simpliciterque praesertim in marginibus costisque. Flores in racemis foliosis terminalibus dispositi. Pedunculi 2-3 $\mathrm{mm}$ longi pilis glandulosis simplicibusque bracteolis anguste ellipticis circa $3 \mathrm{~mm}$ longis. Pedicelli $3-5$ $\mathrm{mm}$ longi articulati. Corolla flava $10-12 \mathrm{~mm}$ longa auriculata pubescens extus et pilis paucis simplicibus intus. Ovulae numerosae in duabus seriebus irregularis in placentis dispersae. Indusium transverse late oblongum circa 1.2 $\mathrm{mm}$ longum setis brevis purpurascentibus super labiis. Capsula ovoidea pubescens 5-6 $\mathrm{mm}$ longa 4-valvulata.

Holotype: Western Australia: 20 miles $(32 \mathrm{~km}$ ) W of Laverton, A.S. George 2798, 22 Aug. 1961. (PERTH).

Prostrate herb with a branched stock. Stems terete, to $13 \mathrm{~cm}$ long, glabrous but for a very few minute hairs towards top and conspicous villous tufts in axils of leaves and bracts. Basal leaves thick, spreading, oblanceolate in outline, lyrate, 7-28 $\mathrm{mm}$ long, 2-5 mm wide, with a well-defined petiole, obtuse, with some minute soft simple hairs especially on margins and lower surface of midrib; cauline leaves, when present, usually less lobed and smaller. Flowers in terminal leafy racemes; bracts elliptic to oblanceolate, 5-9 $\mathrm{mm}$ long, 2-2.5 mm wide, shortly petiolate, entire or with few small teeth; peduncles $2-3 \mathrm{~mm}$ long, sprinkled with some minute glandular and simple hairs; bracteoles narrowelliptic, to elliptic, c. $3 \mathrm{~mm}$ long, and $1 \mathrm{~mm}$ wide; pedicels $3-5 \mathrm{~mm}$ long, similar to peduncles, articulate just below ovary. Sepals narrow-deltoid to lanceolate, 2-3 mm long, $0.4-0.5 \mathrm{~mm}$ wide, acute, sprinkled with minute glandular and 
simple hairs, adnate to ovary for c. $2 / 3$ its length. Corolla yellow, 10-12 mm long, sprinkled with minute soft simple and glandular hairs on outside, with few simple hairs inside, auriculate; anterior pocket indistinct; tube c. $3 \mathrm{~mm}$ long; superior lobes narrow-oblong, c. $6 \mathrm{~mm}$ long and $0.8 \mathrm{~mm}$ wide; inferior lobes narrow-oblong to narrow-deltoid, c. $4 \mathrm{~mm}$ long, $1 \mathrm{~mm}$ wide; wings c. 2 $\mathrm{mm}$ wide; connate part of inferior lobes c. $4 \mathrm{~mm}$ long. Stamen filaments linear, c. $1.5 \mathrm{~mm}$ long; anthers oblong, c. $1.5 \mathrm{~mm}$ long. Ovary tapering gradually towards base, minutely simple- and glandular-pubescent; septum almost as long as loculus; ovules numerous, in two very irregular rows on either side of placenta; style 4-5 $\mathrm{mm}$ long, villous; indusium transverse-broad-oblong, c. $1.2 \mathrm{~mm}$ long and $1.5 \mathrm{~mm}$ wide, purple, villous especially near base on undersurface, \pm convex on upper surface, with a straight orifice beset with purplish bristles c. $0.2 \mathrm{~mm}$ long. Fruit ovoid, 5-6 $\mathrm{mm}$ long, minutely simpleand glandular-pubescent, with a distinct beak, equally 4-valved. Mature seeds not seen.

RANGE: Known only from the type collection.

HABITAT: Red sandy loam.

Discussion: The shape of the capsule, which is \pm equally 4-valved, the indumentum, the numerous somewhat irregularly arranged ovules which appear to give rise to small seeds, and the conspicuous tufts of villous wool in the axils of the leaves all indicate a relationship with $G$. modesta and its allies. $G$. lyrata is distinguished from other members of that group by the lyrate leaves.

Named after the lyrate basal leaves. Latin, lyratus = like a lyre.

G. erecta Ewart in Ewart \& Davies, Fl. N. Territory: $265(1917)=$ G. modesta $J$. Black.

LeCtOTYPE: NoRTHERN TERRITORY: 12 miles $(19.2 \mathrm{~km}) \mathrm{NW}$ of Nth. Terr. Survey Camp III, G.F. Hill 329, 12 June, 1911 (MEL).

G. claytoniacea F. Muell. ex Benth., Fl. Austral. 4: 79 (1868) [as G. Laytoniana, an orthographic error].

Lectotype: Western Australia: Swampy flats of Don River, Maxwell (K). Isolectotype: MEL. Paralectotypes: Drummond 1st coll. 42; Drummond 406 (MEL 23318); Drummond [159] (?MEL 23319), the sheet bearing this specimen has no collector's number but the number ' 159 ' is given in the protologue. Bentham described this species under the binomial 'G. laytoniana F. Muell. Herb'. He cites the specimens indicated above but only one of these is now at $\mathrm{K}$. This, since it agrees with the description, accordingly is selected as the lectotype. Mueller's writing is not always as legible as one would wish and it is fairly clear that Bentham intended to use Mueller's unpublished name but misinterpreted the handwriting. Furthermore, G. claytoniacea has been used consistently since Mueller corrected the name in 1882. Consequently I am herewith accepting the corrected name as legitimate.

G. arthrotricha F. Muell. ex Benth., Fl. Austral. 4: 62 (1868).

Holotype: Western Australia: Drummond 190 (K). Isotypes: BM, MEL 24113.

G. bonneyana F. Muell., Fragm. 6: 226, t.53 (1868)= G. arthrotricha F. Muell. ex Benth.

Lectotype: Western Australia: Drummond 190 (MEL 24113). IsOlectotypes: BM, K. PARALECTOTYPe: The plate, F. Muell., loc. cit. t. 53 (1868). Bentham and Mueller discuss or note each other's descriptions of, and comments on, both the names under consideration. Mueller cites even the page numbers of the reference to both species in Flora 
Australiensis, but Bentham only refers to the plate of $G$. bonneyana and states explicitly that he has not seen the description of it. Despite this, there can only have been a few days or weeks between the issue of Flora Australiensis, vol. 4 on 16th December 1868 (see Stafleu \& Cowan 1976) and Fragmenta vol. 6 'Fine Decembris 1868' as indicated on its last page. The mail ships took about 80 days to make the passage between Melbourne and London so, clearly, both must have had copies of at least part of each other's publications before the date of issue. Mueller probably received the Goodeniaceae proofs for Flora Australiensis in late July since a letter of 23 Sept. 1868 written by him to Bentham seems to be the first indication of his receiving proofs of vol. 4 which he was eagerly awaiting. I have been unable to find any reference to a distribution of the plates of Fragmenta before the publication of the corresponding fascicles. It is probable that Mueller included a print of $G$. bonneyana in the consignment of Goodeniaceae shipped at the beginning of April 1867. There is however, no evidence that this print of tab. 53 of Fragmenta, which would constitute a valid publication of $G$. bonneyana, was distributed to anyone other than Bentham before the fascicle containing the description was issued. The priority then must rest with $G$. arthrotricha since Dec. 16 th can scarcely be taken to be the same as 'Fine Decembris'.

G. coerulea $R$. Br., Prodr.: 578 (1810).

Lectotype: Western Australia: Princess Royal Harbour, King Georges Sound, $R$. Brown, Dec. 1802 (BM). IsOLECTOTYPES: K, MEL, P.*

\section{G. trichophylla Vriese ex Benth., Fl. Austral. 4: 67 (1868).}

Lectotype: Western AUstralia: Drummond 3rd coll. $158(\mathrm{~K})$. IsOlectotype: MEL, P, BM. Paralectotype: Drummond 2nd. coll. $407(\mathrm{~K})$. Drummond no. 158 is selected because the paralectotype has simple hairs on the calyx and corolla - a characteristic not mentioned by Bentham. Indeed he specifically emphasizes the glandular hairs.

\section{G. perryi Gardner ex Carolin, sp. nov.}

Herba ascendens vel erecta usque $25 \mathrm{~cm}$ alta. Folia basalia oblanceolata $4-5 \mathrm{~cm}$ longa gossypine villosa integra fere sessilia. Flores in racemis terminalibus dispositi bracteis anguste oblongis usque linearibus $5-10 \mathrm{~mm}$ longis. Pedunculi bracteolis linearibus 2-6 $\mathrm{mm}$ longis. Sepala lineari-deltoidea $7-8 \mathrm{~mm}$ longa. Corolla coerulea glabra extus sed pilis paucis atque enationibus intus auriculata plus minusve distincta. Ovarium villosum septo longitudinem loculi fere aequanto. Indusium suborbiculare c. $2 \mathrm{~mm}$ longum.

Holotype: Western Australia: Bunjil, C.A. Gardner 15 Oct. 1961 (PERTH).

Ascending or erect herb to c. $25 \mathrm{~cm}$ with a branched stock. Stems obscurely ridged when young becoming \pm terete, cottony hairy. Basal leaves oblanceolate, 4-5 cm long, 6-10 mm wide, tapering very gradually towards broadened base, obtuse, entire, cottony with multicellular cells; cauline leaves similar but smaller. Flowers in terminal thyrses or racemes; bracts mostly narrow-oblong to linear, 5-10 mm long, 0.5-2 mm wide, sessile, acute, cottony-villous, lower ones somewhat broader and more leaf-like; bracteoles linear, 2-6 mm long, $0.5 \mathrm{~mm}$ wide, cottony-pubescent. Sepals linear-deltoid, 7-8 mm long, 0.5-0.8 mm wide, acute, entire, cottony-pubescent on both surfaces, adnate to ovary almost to its summit. Corolla blue, with yellowish throat, 15-18 mm long, glabrous outside, with very few short hairs and rows of enations inside, auriculate; anterior pouch indistinct, $1 / 2-2 / 3$ as long as ovary; tube c. $3 \mathrm{~mm}$ long; superior lobes oblong-oblanceolate, $15 \mathrm{~mm}$ long, $2 \mathrm{~mm}$ wide; inferior lobes oblong, 8-9 $\mathrm{mm}$ long, $2.5 \mathrm{~mm}$ wide; wings c. $3 \mathrm{~mm}$ wide; connate part of inferior lobes $8-10$ $\mathrm{mm}$ long. Stamen filaments linear, c. $4 \mathrm{~mm}$ long; anthers narrow-oblong, 1.5 $\mathrm{mm}$ long. Ovary cottony-villous; septum almost as long as loculus; ovules c. 40; style $6 \mathrm{~mm}$ long, villous-pubescent; indusium suborbicular, c. $2 \mathrm{~mm}$ diam., 
brownish, villous-pubescent, with a curved orifice beset with white bristles $\mathrm{c}$. $0.5 \mathrm{~mm}$ long. Fruit and seed unknown.

RANGE: Known only from the type collection.

HABITAT: Unknown.

DiscUSSION: This species shows some similarity to $G$. incana, from which it can easily be distinguished by the glabrous outer surface of the corolla.

The species epithet probably commemorates Dick Perry, a forester who spent some time in the field with C.A. Gardner, including the Bunjil area (Maslin, pers. comm.).

G. incana $R$. Br., Prodr.: 578 (1810).

Lectotype: Western Australia: Bay I, South Coast, R. Brown, 7 Jan. 1804; (BM). ISOLECTOTYPE: K.* The lectotype is mounted on the same sheet as 'Chotarup, F.V. Mueller' \& 'Drummond 3 Coll. no. 155'.

G. pterigosperma $R$. Br., Prodr.: 578 (1810).

ORTHOGRAPHIC VARIANT: G. pterygosperma Vriese, Natuurk. Verh. Holl. Maatsch. Wetensch. Haarlem ser. 2, 10: 153 (1854).

Lectotype: WeStern Australia: Bay I (Lucky Bay) South Coast, R. Brown, 12 Jan. 1802 (BM). ISOLECTOTYPE: (K).* The isolectotype of G. pterigosperma at $\mathrm{K}$ contains a fragment of another species which I have been unable to identify with certainty.

G. cyanea F. Muell., Fragm. 1: 155 (1859) = G. pterigosperma $R$. $B r$.

Lectotype: Western Australia: [Phillip's Range], Maxwell (K). ParalectotyPes: uncertain. There are no specimens from Phillips Range, the locality given in the protologue, which have been labelled $G$. cyanea by Mueller. The closest to it seems to be the specimen at K, labelled by Mueller, from S.W. Australia. Mueller probably used other material, which was subsequently labelled ' $G$. pterygosperma', for his description of $G$. cyanea, before sending it to Kew for Bentham to use in Flora Australiensis. The specimen selected as the lectotype is labelled $G$. cyanea in Mueller's handwriting, and agrees with his description.

\section{G. glareicola Carolin, sp. nov.}

Herba erecta caulorrhiza basibus emortuis foliarum obtecta. Scapi glabri ad 30 $\mathrm{cm}$. Folia basalia linearia usque oblanceolata crassa glabra integra obtusa sessilia. Flores in racemis terminalibus dispositi. Sepala lanceolata $1.5-4 \mathrm{~mm}$ longa glabra. Corolla coerulea sed flava in fauce ad $15 \mathrm{~mm}$ longa glabra extus et intus atque seriebus enationum auriculata sacco angusto ovarium aequans. Ovarium glabrum stylo villoso indusioque latissimo obovato. Fructus ovoideus 8-9 mm longus plerumque quatuor valvis dehiscens. Semina plana brunnea reticulata elliptica ala lata hyalina.

Holotype: Western AUSTRalia: Near Newdegate, W.E. Blackall 1364, 18 Nov. 1931 (PERTH).

Glabrous often glaucous erect perennial herb with thickened stock surrounded by dead leaf-bases, with slightly thickened tap-root. Scapes terete or slightly angular when young, to $30 \mathrm{~cm}$ high, 2-3 mm thick. Basal leaves thick, linear to oblanceolate, $20-30 \mathrm{~mm}$ long, 2-4 mm wide, sessile with broadened base, entire, glabrous except for some villous wool in axils; upper leaves becoming smaller. Flowers in terminal racemes, lower peduncles occasionally bearing two flowers; peduncles 8-20 mm long; bracteoles linear-lanceolate, $2.5-3 \mathrm{~mm}$ long; pedicels 5-14 $\mathrm{mm}$ long, articulate c. $1.5 \mathrm{~mm}$ below ovary. Sepals lanceolate, 
1-4 mm long, acute, adnate to ovary almost to its summit. Corolla blue, yellow in throat, c. $15 \mathrm{~mm}$ long, glabrous outside, with some very short hairs and obscure enations inside, auriculate; anterior pocket narrow but as long as ovary; tube 2-3 mm long; superior lobes narrow-oblong to oblanceolate, 7-7.5 $\mathrm{mm}$ long, c. $1.5 \mathrm{~mm}$ wide; inferior lobes narrow-ovate, $6.5-7 \mathrm{~mm}$ long, to 2 $\mathrm{mm}$ wide; wings $2-2.5 \mathrm{~mm}$ wide; connate part of inferior lobes $4.5-5 \mathrm{~mm}$ wide. Stamen filaments linear, $2.5 \mathrm{~mm}$ long; anthers oblong, $1.5 \mathrm{~mm}$ long. Ovary glabrous; septum nearly as long as loculus; style to $6 \mathrm{~mm}$ long, villous; indusium broad-ovate, $1.5 \mathrm{~mm}$ long, $2 \mathrm{~mm}$ wide, brownish, with a slightly curved orifice beset with bristles c. $0.4 \mathrm{~mm}$ long which are purplish at tips. Fruit ovoid, 8-9 mm long, 2-valved to base, each valve often bifid. Seeds flat, brown, elliptic, $2 \mathrm{~mm}$ long, reticulate; wing hyaline, c. $0.7 \mathrm{~mm}$ wide.

RANGE: Hyden to Tammin, Western Australia.

HABITAT: Gravelly sands.

Discussion: The lack of hairs and the broad hyaline wing on the seed distinguish this species from other members of sect. Coerulea.

Selected Specimens (23): Western Australia: Bundering, C.A. Gardner 2026, 15 Nov. 1923 (PERTH); 16 miles (25.6 km) N of Lake Biddy, W.E. Blackall 1364, 18 Nov. 1931 (PERTH); Frank Hann National Park, R.D. Royce 10199, 10 Dec. 1971 (PERTH); Tammin, C.A. Gardner 12116, 26 Nov. 1953 (PERTH); 12 miles $(19.2 \mathrm{~km}) \mathrm{W}$ of Ballidu, J.W. Green 768, 3 Nov. 1956 (PERTH).

Named after the gravelly soils in which this species is sometimes found. Latin, glarea $=$ gravel, - icola $=$ living in.

\section{G. eatoniana F. Muell., Fragm. 8: 186 (1874)}

Lectotype: Western Australia: Blackwood River, Jas. Forrest (MEL 22369). ProbABLE ISOLECTOTYPE: K.* Mueller simply cites 'In Australia extratropica occidentali ad flumen Blackwood River'. There are a number of collections from the Blackwood River but of these it would seem that only that of John Forrest, who was in that area in 1870, was actually made before Mueller's description in 1873. One of these sheets is therefore selected as the lectotype. The collector's name on the herbarium label 'Jas. Forest' is presumably a mistake for 'John Forrest'.

G. hassallii F. Muell., Fragm. 6: 10 (1867).

LeCtOTYPE: Western Australia: In Australis occidentali, Drummond s.n. (MEL) 24091. ISOLECTOTYPE: K. MEL 24006*

\section{G. nigrescens Carolin, sp. nov.}

Herba erecta usque $20 \mathrm{~cm}$ alta nigrescens vel memnonia si siccata. Folia anguste oblonga vel oblanceolata $2-5 \mathrm{~cm}$ longa glabra vel strigosa integra vel dentata versus basin sensim in petiolum contracta. Flores in racemis terminalibus dispositi bracteis foliosis sed linearibus. Pedunculi 5-18 mm longi bracteolis linearibus duabus circa $2-3 \mathrm{~mm}$ infra ovario insertis. Sepala linearilanceolata vel anguste elliptica $4-5 \mathrm{~mm}$ longa. Corolla ochracea pubescens simpliciter et glandulose extus et villosis enationibus pilis fere occultis intus. Capsula ovoido-cylindrica usque $1.5 \mathrm{~cm}$ longa glabrescens duabus valvis ad basim dehiscens. Semina orbicularia usque $3 \mathrm{~mm}$ in diametro reticulata ala angusta.

Holotype: NorThern Territory: 28 miles (44.8 km) NE of Banka Banka, G. Chippendale, 16 June 1960 (NT 7023).

Erect perennial or annual herb to $20 \mathrm{~cm}$, becoming dark-brown or black when dried, with a branched stock c. $0.3 \mathrm{~mm}$ wide. Stems compressed, distinctly 
ridged, glabrous. Leaves scattered on stem, narrow-oblong to oblanceolate, 2-5 $\mathrm{cm}$ long, 3-5 mm wide, narrowing very gradually towards base, entire dentate or lobed, obtuse, glabrous or with minute glandular hairs when young, with a tuft of villous axillary hairs. Flowers in terminal racemes; bracts linear, to $5 \mathrm{~cm}$ long, to $3 \mathrm{~mm}$ wide at base of raceme but mostly c. $3 \mathrm{~mm}$ long and $1 \mathrm{~mm}$ wide, entire or dentate, glabrous; peduncles 5-18 mm long, glabrous; bracteoles linear, $2-3 \mathrm{~mm}$ long, c. $0.5 \mathrm{~mm}$ wide, glabrous or with few appressed simple hairs, sometimes not exactly opposite; pedicels 1-2 mm long, glabrous, articulate. Sepals linear-lanceolate to elliptic or narrow-elliptic, 4-5 mm long, 0.5 $\mathrm{mm}$ wide, acute, entire, nearly glabrous but usually with very few appressed simple and glandular hairs, adnate to ovary for $3 / 4$ its length. Corolla deep yellow, brownish in throat, c. $18 \mathrm{~mm}$ long, densely pubescent outside with glandular and simple hairs, with villous-pubescent hairs arranged in basally widening zones and obscure enations almost hidden by hairs which frequently surmount them inside, auriculate; anterior pouch scarcely as long as ovary; tube 1-2 mm long; superior lobes narrow-oblong, c. $10 \mathrm{~mm}$ long, c. $1 \mathrm{~mm}$ wide, winged on upper margin only, barbulate on lower margin; inferior lobes oblong, $\mathrm{mm}$ long, 2-2.5 mm wide; wings $2-2.8 \mathrm{~mm}$ wide; connate part of inferior lobes 6-7 mm long. Stamen filaments linear, $2.5 \mathrm{~mm}$ long; anthers oblong, $1.5 \mathrm{~mm}$ long. Ovary with a few scattered appressed simple and glandular hairs; septum c. $2 / 3$ as long as loculus; ovules c. 30 ; style $3.5-4 \mathrm{~mm}$ long, glabrous; indusium oblong-ovate, $2.5 \mathrm{~mm}$ long, $1.5-2 \mathrm{~mm}$ wide, sprinkled with villous hairs, concave to slightly folded, with a curved orifice beset with white bristles c. $0.5 \mathrm{~mm}$ long on upper lip and shorter ones on lower lip. Fruit ovoid-cylindrical, \pm compressed, $1.2-1.5 \mathrm{~cm}$ long, $0.4-0.5 \mathrm{~cm}$ wide, almost glabrous, 2-valved to base, each valve entire. Seeds flat, brown, orbicular, $4.3 \mathrm{~mm}$ diam., reticulatefoveate, with an obscure rim; wing $0.2-0.3 \mathrm{~mm}$ wide.

RANGE: Barkly Tablelands in the Northern Territory.

HABITAT: Grey soils.

DISCUSSION: This species is distinguished from others which have strigose hairs and bracteoles, by the narrow indusium, the glandular pubescence on the outside of the corolla, the lack of a lower wing on the superior corolla lobes and the narrow wing on the seed.

SPECIMENS EXAMINED: NORTHERN TERRITORY: 7 miles $(11.2 \mathrm{~km}) \mathrm{N}$ of Brunchilly, $G$. Chippendale, 17 June 1960 (NT 7064); 17 miles (27.2 km) NW of Brunette Downs HS., G. Chippendale, s.d. (NT 5017); 28 miles $(44.8 \mathrm{~km})$ NE of Alexandria Stn. HS., C.S. Christian 1545, 15 June 1948 (CANB 109464).

Named from its showing a marked tendency to blacken when dried. Latin, nigrescens $=$ becoming black.

G. fascicularis F. Muell. \& Tate, Trans. \& Proc. Roy. Soc. South Australia 13: 108 (1890).

Holotype: South Australia: Basedow Ranges, Tietkens, 1889 (MEL). This name has been overlooked until recently. Unfortunately it predates the name previously used for this species, viz. $G$. subintegra. The type of $G$. fascicularis is a poor specimen with linear basal leaves and villous hairs on the back of the indusium. Many other specimens also have villous hairs on the indusium despite the numerous statements in the literature to the contrary.

G. subintegra F. Muell. ex J. Black, Trans. \& Proc. Roy. Soc. South Australia 51: $383(1927)=$ G. fascicularis F. Muell. \& Tate. 
Lectotype: New South Wales: Darling River, Dallachy (K). This is the same specimen chosen as the lectotype for G. glauca var. sericea Benth. Mueller in Victorian Naturalist 5: 13 (1888) writes 'This plant to which as a mere variety or as a distinct species the name subintegra may be assigned....' This, of course, is not valid publication. Black cites no specimens but refers to Mueller's statement given here. I am therefore accepting that $G$. subintegra is G. glauca var. sericea Benth., raised to specific rank.

G. glauca var. sericea Benth., Fl. Austral. 4: $77(1868)=$ G. fascicularis $F$. Muell. \& Tate.

Lectotype: New South Wales: Darling River, Dallachy (K). Paralectotypes: Sturt's Creek and Dawson River, F. Mueller (MEL 23532); In the Interior, Mitchell (K, MEL 23562); Plains of the Condamine, Leichhardt (MEL 23551?); Armadillo, W. Barton (MEL 23554, NSW 76573). Bentham only makes indirect reference to specimens he referred to this species, but there are two labelled by him with Flora Australiensis labels at $\mathrm{K}$. One of these has been selected as the lectotype.

G. glauca F. Muell., Trans. \& Proc. Victorian Inst. Advancem. Sci.: 40 (1855).

LECTOTYPE: Victoria: On the grassy banks of the Avoca, s. c., s.d. (MEL). ParaLECTOTYPES: K, MEL. There are several sheets from this locality in MEL and it is not clear if they are from the same collection. One I have marked as the lectotype.

G. lunata J. Black, Trans. \& Proc. Roy. Soc. South Australia 51: 384 (1927).

Lectotype: South Australia: Cordillo Downs, J.B. Cleland, 27 May 1924 (AD97006372). PARAlectotyPes: Macumba River, J.B. Cleland (AD); Alberga River, $H . W$. Andrews (AD97006371). The typification of $G$. lunata presents a serious problem. The specimens from Black's herbarium labelled with this name are poor, none of them having intact indusia which bear the characters that distinguish the species. There is, however, a drawing of an indusium on AD 97006371 which makes it clear that this, at any rate, was taken from a specimen of $G$. lunata. Unfortunately two specimens are mounted on this sheet with the note, by someone other than J. Black, that it was difficult to decide which specimen belonged to which label. In fact one of these labels is not cited by Black and therefore that collection has no claim to any sort of type status: this drawing is most probably from the non-type material. The only specimen that one can be sure has type status, i.e. the one sheet AD 97006372, is a very poor specimen with no flowers and no drawings of flowers. There appears to be no choice but to select this as the lectotype.

\section{G. argentea J. Black, op. cit.: $384(1927)=$ G. lunata $J$. Black}

LeCtotype: South Australia: Strangeways Springs, W.L. Cleland, no date (AD 96845153). Isolectotype: K. PARAlectotyPe: Yadlakina Soak (east of Lake Torrens), s.c. (AD).

\section{G. pascua Carolin, sp. nov.}

Herba strigosa erecta vel ascendens usque $50 \mathrm{~cm}$. Folia anguste elliptica vel oblanceolata 4-8 cm longa integra vel dentata versus basim sensim in petiolum contracta et in rosulis disposita. Flores in racemis terminalibus laxis vel subumbellatim dispositi pedunculis ebracteolatis articulatis. Septum ovarii breve. Lobi inferiores corollae alis inaequalibus. Capsula ovoido-ellipsoidea duabus valvis integris dehiscens. Semina elliptica reticulata brunnea, ala 0.3-0.4 mm lata.

Holotype: Western Australia: 11 miles $(17.6 \mathrm{~km})$ from Roeburne on Port Hedland road, R.C. Carolin 7894, 14 Aug. 1970 (NSW). 
Ascending to erect herb, with short stock and thin tap-root, with strigose simple hairs. Scapes terete, to $50 \mathrm{~cm}$ long. Leaves mostly basal, spreading, narrowelliptic-oblanceolate, $4-8 \mathrm{~cm}$ long, $5-10 \mathrm{~mm}$ wide, tapering very gradually towards base, entire to dentate, with strigose hairs and long cottony multicellular hairs the latter becoming less frequent with age, with a small tuft of villous axillary hairs; cauline leaves much smaller and narrower. Flowers in terminal racemes or subumbels; bracts mostly linear, 2-12 $\mathrm{mm}$ long, to $1 \mathrm{~mm}$ wide; peduncles 2-4 cm long, articulate c. $1 \mathrm{~mm}$ below ovary; bracteoles absent. Sepals lanceolate, c. $2 \mathrm{~mm}$ long, adnate to ovary for $2 / 3-3 / 4$ of its length. Corolla yellow with brownish markings in throat, $8-10 \mathrm{~mm}$ long, strigose outside, with a few villous hairs inside particularly in throat, auriculate; anterior pocket distinct, $1 / 2-2 / 3$ as long as ovary; tube $2-2.5 \mathrm{~mm}$ long; superior lobes narrowoblong, 5-5.5 mm long, 1-1.5 mm wide; inferior lobes ovate-oblong, 4-4.5 $\mathrm{mm}$ long, c. $1.5 \mathrm{~mm}$ wide; wings c. $1.5 \mathrm{~mm}$ wide, wing above auricle $0.5 \mathrm{~mm}$ wide and c. $2 / 3$ as long as lobe; connate part of inferior lobes $3-3.5 \mathrm{~mm}$ long. Stamen filaments $1.5 \mathrm{~mm}$ long; anthers oblong, $1 \mathrm{~mm}$ long. Ovary strigose; septum c. $1 / 2$ as long as loculus; ovules 23-35; style c. $3 \mathrm{~mm}$ long; indusium square to transverse-elliptic, to $1.7 \mathrm{~mm}$ long, to $2 \mathrm{~mm}$ wide, brownish, slightly convex, pubescent on both surfaces, with a \pm concave orifice beset with white bristles $c$. $0.3 \mathrm{~mm}$ long. Fruit ovoid-ellipsoid, sightly compressed, 2-valved to the base, each valve entire. Seeds flat, brown, elliptic, c. $3 \mathrm{~mm}$ long, reticulate; wing pale brown, to $0.5 \mathrm{~mm}$ wide.

RANGE: North-western Australia west of the Great Sandy Desert.

HABITAT: Grassy plains on heavy soils.

Discussion: The size and shape of the fruit and, in particular, the unequal wings on the superior corolla lobes of this species separate it from G. glauca and its allies, although the indumenta are very similar.

SPECIMENS EXAMined: Western Australia: 50 miles $(80 \mathrm{~km})$ from Onslow on Roebourne road, R.C. Carolin 7859, 11 Aug. 1970 (SYD, PERTH); 127 miles (203 km) from Onslow on Roebourne road, R.C. Carolin 7846, 11 Aug. 1970 (SYD); 322 miles $(51.2 \mathrm{~km})$ from Dampier on Onslow road, R.C. Carolin 7886, 12 Aug. 1970 (SYD); 21 miles $(33.6 \mathrm{~km}) \mathrm{N}$ of Sandy Creek on Rabbit Proof Fence, R.D. Royce 1687, 15 May 1947 (PERTH).

Named after its habitat in open grassy plains. Latin, pascuus = relating to pastures.

\section{G. heteromera F. Muell., Fragm. 1: 115 (1858).}

LECTOTYPE: VICTORIA?: In moist grassy places on the Murray River, s.c., s.d. (MEL 23624). PARALECTOTYPES: The protologue gives Murray, Darling and Avoca Rivers. There are a number of specimens at MEL collected on these Rivers which would have been available to Mueller when he cast the diagnosis: the one selected is the most complete of these specimens.

G. tenella $R$. Br., Prodr.: 577 (1810) non $A n d r$, Bot. Repos. 7: t.466 (1807), nom. superfl.

Holotype: Western Australia: King George's Sound, Mr. Bauer (BM). Isotype: K. G. tenella Andr. is fortunately a superfluous name since Andrews writes '.. and is by Labillardère figured under the title of Velleia trinervis'.

G. tenella var. major Benth., Fl. Austral. 4: 74 (1868) = G. tenella $R$. $B r$.

Lectotype: WeStern Australia: Don River, Maxwell (K). IsOlectotype: MEL. PARALECTOTYPES: Karridale, Herb. F. Mueller (MEL). 
G. anfracta J. Black, Trans \& Proc. Roy. Soc. South Australia 51: 385 (1927).

Holotype: South Australia: Cootanoorina, R. Helms, May 1891 (AD 96620136). AD 96845148 is probably a dissected flower from the holotype with notes and drawings.

G. coronopifolia $R$. $B r$., Prodr.: 576 (1810).

LectotyPe: NORTHERN TERritORY: Carpentaria Island 5 (i.e. Morgan's Island), $R$. Brown, 20-21 Jan. 1803 (BM). IsOlectotyPES: MEL 23310, 23312, 23309, P, K.* The specimen MEL 23311 labelled 'North Coast, 1803, R. Brown' may also be an isotype.

Although this name is given in Blackall \& Grieve, How to Know W. Australian Wildflowers 431 (1956), it is not clear to which species it refers. Since $G$. coronopifolia is not so far recorded from the area covered by their work, it is doubtful if they were, in fact, referring to $G$. coronopifolia. Even more doubtful is the reference to this species by Christensen \& Ostenfeld, Det. Kgl. Dan. Selsk., Biol. Medd., 3: 123 (1921) but I have not examined the specimen concerned, viz. Armadale, Christensen \& Olstenfeld 1121, 20 Sept. 1914.

\section{G. integerrima Carolin, sp. nov.}

Herba ascendens vel decumbens usque circa $9 \mathrm{~cm}$ alta caulibus teretibus glabris. Folia crassa linearia usque $7 \mathrm{~cm}$ longa integra supra canaliculata strigosa. Flores in umbellis foliosis terminalibus dispositi pedunculis ebracteolatis circa $5 \mathrm{~mm}$ longis. Corolla flava sed brunnea in fauce $7 \mathrm{~mm}$ longa glabra extus pubescens intus in fauce. Lobi superiores corollae ala inferiore reducta auriculata. Capsula globula circa $2.5 \mathrm{~mm}$ diametro glabra. Semina orbicularia circa $1.5 \mathrm{~mm}$ diametro reticulata fumosa ala $0.3 \mathrm{~mm}$ lata.

Hototype: Western Australia: Lake King, A.S. George 7291, 3 Nov. 1965 (PERTH).

Decumbent to ascending herb to c. $9 \mathrm{~cm}$. Stems terete, glabrous. Leaves thick, fasciculate, linear, to $7 \mathrm{~cm}$ long, 1-2 $\mathrm{mm}$ wide, sessile with a broadened base, acute, involute with a narrow channel on upper surface, with a few short scattered \pm appressed simple hairs. Flowers arranged in terminal umbels; bracts leaf-like but smaller; pedicels c. $5 \mathrm{~mm}$ long, with very few short scattered hairs, indistinctly articulate just below ovary; bracteoles absent. Sepals narrowdeltoid, c. $3 \mathrm{~mm}$ long and $0.6 \mathrm{~mm}$ wide, acute, entire, glabrous, adnate to ovary for $2 / 3-3 / 4$ its length. Corolla yellow with brownish throat, c. $7 \mathrm{~mm}$ long, glabrous outside, \pm pubescent inside in throat; anterior pocket indistinct, c. $1 / 2$ as long as ovary; tube c. $2 \mathrm{~mm}$ long; superior lobes narrow-oblong, c. $4 \mathrm{~mm}$ long and 0.5 $\mathrm{mm}$ wide, lower wing almost obsolete above auricle; inferior lobes oblong, 2 $\mathrm{mm}$ long, $1 \mathrm{~mm}$ wide; wings $\mathrm{c}$. $1 \mathrm{~mm}$ wide, scarcely $1 / 2$ as long as lobes; connate part of inferior lobes c. $3 \mathrm{~mm}$ long. Stamen filaments linear, $1.5 \mathrm{~mm}$ long; anthers elliptic, $0.8 \mathrm{~mm}$ long. Ovary glabrous; septum scarcely $1 / 2$ as long as loculus; ovules 6-8; style 2-2.5 mm long, pubescent towards top; indusium transverse-oblong, $0.8 \mathrm{~mm}$ long, $1.5 \mathrm{~mm}$ wide, brownish, villous-pubescent, with \pm concave orifice beset with white bristles c. $2 \mathrm{~mm}$ long. Fruit globular, c. $2.5 \mathrm{~mm}$ diam., glabrous. Seeds flat, dark grey-brown, orbicular, c. $1.5 \mathrm{~mm}$ diam., reticulate, with prominent rim; wing c. $0.3 \mathrm{~mm}$ wide, mucilaginous.

RANGE: Known only from type collection.

HABITAT: (Sandy) margins of salt lakes.

Discussion: This species is not closely allied to any other species, but the form of the few hairs and the seeds indicate a relationship with the $G$. fascicularis group more than with any other.

Named after the entire leaves. Latin, integerrimus = quite entire. 
G. neogoodenia Carolin, nom. nov.

REPLACED NAME: Neogoodenia minutiflora Gardner \& George, J. Roy. Soc. W. Australia 46:138 (1963). The epithet 'minutiflora' is pre-occupied by Goodenia minutiflora F.Muell.

G. janamba Carolin, sp. nov.

Herba erecta usque $60 \mathrm{~cm}$. Folia plerumque basalia ascendentes anguste oblonga ad oblanceolata $5-16 \mathrm{~cm}$ longa fere glabra plus minusve crassa. Flores in racemis vel subumbellatum terminaliter dispositi pedunculis ebracteolatis molliter patenter simpliciter glanduloseque pubescentibus. Corolla flava 10-15 $\mathrm{cm}$ longa simpliciter ac glandulose pubescens extus sparse villosa intus sacco prominentissimo. Capsula globula c. $4 \mathrm{~mm}$ diametro. Semina orbicularia c. 4 $\mathrm{mm}$ diametro nitida ala albida $1 \mathrm{~mm}$ lata.

Holotype: Northern Territory: c. 10 miles $(16 \mathrm{~km}) \mathrm{E}$ of South Alligator River on Oenpelli road, R.C. Carolin 6817, 16 May 1968 (NSW). IsOTYPE: SYD.

Erect herb with short basal stock, a narrow tap root and usually many adventitious roots. Scapes terete, branched, to $60 \mathrm{~cm}$, glabrous or nearly so. Leaves mostly basal, slightly thickened, narrow-oblong to oblanceolate, $5-16 \mathrm{~cm}$ long, 2-7 mm wide, narrowing very gradually towards base, \pm acute, with a few blunt teeth on margin, glabrous except for some simple hairs towards base. Flowers in terminal umbels or racemes; bracts linear, 4-7 $\mathrm{mm}$ long, entire, with a few scattered simple hairs; peduncles $2-5 \mathrm{~cm}$ long, with soft simple patent hairs and minute glandular ones especially towards top, articulate c. $1 \mathrm{~mm}$ below ovary; bracteoles absent. Sepals deltoid, c. $0.5 \mathrm{~mm}$ long and $0.3 \mathrm{~mm}$ wide, acute, entire, simple- and glandular-pubescent, adnate to ovary for c. $2 / 3$ its length. Corolla yellow, 10-15 mm long, simple- and glandular-pubescent outside, with some scattered villous hairs inside especially on connate part of inferior lobes, auriculate; anterior pouch very prominent, almost as long as ovary; tube 3-4 mm long; superior lobes narrow-oblong, 5-8 mm long, c. $1 \mathrm{~mm}$ wide; inferior lobes oblong, 3-6 $\mathrm{mm}$ long, $1 \mathrm{~mm}$ wide; wings $1 \mathrm{~mm}$ wide, c. $2 / 3$ as long as lobes; connate part of inferior lobes $4-5 \mathrm{~mm}$ long. Stamen filaments linear, c. $1.5 \mathrm{~mm}$ long; anthers oblong, c. $0.5 \mathrm{~mm}$ long. Ovary glandular- and simple-pubescent; septum c. $1 / 2$ as long as loculus; ovules $10-12$; style c. $5 \mathrm{~mm}$ long, glabrous or nearly so; indusium obtriangular, c. $1 \mathrm{~mm}$ long, c. $2 \mathrm{~mm}$ wide, brownish, villous-pubescent especially on upper surface, with an almost straight orifice beset with short white bristles c. $0.1 \mathrm{~mm}$ long on upper lip and much longer $(0.5 \mathrm{~mm})$ on lower lip of which the longest ones are reflexed. Fruit globular, \pm compressed, c. $4 \mathrm{~mm}$ diam., glandular- and simple-pubescent, 2valved but not to base, each valve entire. Seeds flat, yellowish, orbicular, c. 4 mm diam., smooth, glossy, reticulate-foveate, with a distinct rim; wing $1 \mathrm{~mm}$ wide, whitish.

RANGE: Darwin-Gulf District of Northern Territory and the Croydon area of Queensland.

HABITAT: Savannah woodlands on sands and stony hillsides.

Selected Specimens (15): Northern Territory: Port Darwin, M. Holtze 702, Oct. 1888 (MEL 22261); 1 mile (1.6 km) N of Adelaide River township, N. Byrnes NB650, 1 May 1968 (NT 14381, SYD); Goodparla Stn., R.C. Carolin 6789, 15 May 1968 (SYD); c. 5 miles $(8 \mathrm{~km}) \mathrm{E}$ of Mary River on Oenpelli to Pine Creek road, R.C. Carolin 6748, 14 July 1968 (SYD); 30 miles (48 km) E of Berwick Hs., R.C. Carolin 9362, 21 May 1974 (SYD); 22 miles $(35.2 \mathrm{~km}$ ) from Boroloola on road to Daly Waters, R.C. Carolin 9310 , 18 May 1974 (SYD). QUEENSLAND: 44 miles $(70.4 \mathrm{~km})$ E. of Croydon on Georgetown road, R.C. Carolin 8612, 15 April 1974 (SYD). 
'Janamba' is an Aboriginal word meaning crocodile and this species is named for the South Alligator River, near which the type specimen was collected.

G. strangfordii F. Muell., Fragm. 6: 11 (1867).

LectotyPe: QueEnSLAND: Lara, Flinders River, Kennedy (MEL 23739). Paralectotype: Upper Victoria River, F. Mueller (K, MEL 23744). Mueller gives 'In locis ripariis a fluvo Victoriae usque ad rivum Flindersii'. The specimen from the Flinders River at MEL agrees with the illustration accompanying the type description much better than the Victoria River specimen at Kew even to the point of possessing the rare feature in this species of a bracteolate peduncle. This is therefore selected as the lectotype.

\section{G. pusilliflora F. Muell., Victorian Naturalist 5: 11 (1888).}

LectotyPE: New SOUTH Wales?: Junction of Murray and Darling Rivers, Mrs. Holding, July 1887 (MEL 23136). ParalectotyPes: Yorkes Peninsula, O. Tepper (MEL 23140, 23141, 23146); Near the Broughton River, L. Wehl (MEL 23154); Richardsons Creek, Curdie (MEL 23138); Wimmera, D. Sullivan (MEL 23149); Lake Coorong, C. Walter (MEL 23137); Looma Rapids, Cambell (MEL 23130); Lake Albacutya, C. French (MEL 23134, 23135, 23142); Edwards River, F. Mueller (MEL 23129?); Murrumbidgee, Lucas (MEL 231 39?, 23147?, 23148?); Tarella, W. Baueuerlen (MEL); Near Flinders Range, $F$. Mueller [not located], Near Mt. Perry, Tate (MEL); Darling River, Brueckner (MEL); Lachlan River, F. Mueller (MEL)]. The description in Victorian Naturalist appears to be the first since it was published in May 1888. Mueller's description in Bot. Centralbl. 35: 99 (1888) is virtually a copy of it and seems to have been published later in the same year. Mueller also described this species in his Key to the System of Victorian Plants which was published between November and December 1888 .

G. calogynoides E. Pritzel, Bot. Jahrb. Syst. 35: $560(1905)=$ G. pusilliflora $F$. Muell.

Lectotype: Western Australia: District Avon, bei Newcastle, E. Pritzel 550, Aug. 1901 (BM). ParalectotyPE: Newcastle, Diels 3907 (B destroyed). Despite Krause's distinction between $G$. pusilliflora and $G$. calogynoides, 'Indusium integrum' and 'Indusium bilobum' respectively, the two may not be different. In fact $G$. pusilliflora has a cleft indusium, certainly never quite entire, and Mueller himself drew attention to it $\therefore$ slightly contracted in the middle so as to indicate some approach to that of Calogyne ......

\section{G. phillipsiae Carolin, sp. nov.}

Suffrutex erectus vel ascendens usque $30 \mathrm{~cm}$. Folia caulina crassa anguste oblonga vel linearia usque $4 \mathrm{~cm}$ longa sessilia glabra integra. Flores in thyrsis terminalibus dispositi pedunculis bracteolatis arcuatis $15-30 \mathrm{~mm}$ longis. Corolla flava 10-12 $\mathrm{mm}$ longa extus glabra intus conferte hirsuta sacco prominenti et lobis inaequalibus late alatis. Ovarium glabrum septo loculum fere aequanti.

Holotype: WeStern Australia: 19 miles $(30.4 \mathrm{~km})$ E of Ravensthorpe, M.E. Phillips, 3 Nov. 1962 (PERTH).

Erect to spreading suffruticose perennial to $30 \mathrm{~cm}$. Stems obscurely ridged to terete, glabrous. Cauline leaves thick, narrow-oblong to linear, to $4 \mathrm{~cm}$ long, to $3 \mathrm{~mm}$ wide, sessile, entire, glabrous. Flowers in complex terminal thyrses; bracts similar to cauline leaves but smaller; peduncles $15-30 \mathrm{~mm}$ long, glabrous, arcuate; bracteoles thick, linear, to $10 \mathrm{~mm}$ long, c. $0.5 \mathrm{~mm}$ wide, glabrous, acute; pedicels similar to peduncles but shorter; partial inflorescences often many-flowered. Sepals elliptic-lanceolate, $2 \mathrm{~mm}$ long, $0.5 \mathrm{~mm}$ wide, acute, glabrous, adnate to ovary for almost its whole length. Corolla yellow (?), 10-12 mm long, glabrous outside but with a dense beard inside at base of 
inferior lobes and then pubescent below, scarcely auriculate; anterior pouch prominent, c. $1 / 3$ as long as ovary; tube $4.5-5 \mathrm{~mm}$ long; superior lobes oblong, c. $8 \mathrm{~mm}$ long, c. $1.8 \mathrm{~mm}$ wide; inferior lobes oblong, c. $6 \mathrm{~mm}$ long, c. $1.5 \mathrm{~mm}$ wide; wings c. $1.5 \mathrm{~mm}$ wide; connate part of inferior lobes c. $5 \mathrm{~mm}$ long. Stamen filaments c. $2.5 \mathrm{~mm}$ long; anthers oblong, $1.5 \mathrm{~mm}$ long. Ovary glabrous; septum almost as long as loculus; ovules 45-50; style c. $5 \mathrm{~mm}$ long, villous; indusium depressed-obovate, $1 \mathrm{~mm}$ long, $2 \mathrm{~mm}$ wide, pubescent at base particularly on posterior side, with a slightly curved orifice beset with white bristles c. $0.4 \mathrm{~mm}$ long. Fruit and seed unknown.

RANGE: Known only from the type collection.

HABITAT: Unknown.

DisCUSSION: A species of uncertain relationship until more is known about its morphology and distribution. The bracteolate inflorescence with arcuate peduncles and pedicels appears to be diagnostic. The beard on the corolla points to a relationship with $G$. pinnatifida but the presence of bracteoles is unusual in the group centred on that species.

Named for the late Marie E. Phillips, the collector of the holotype, formerly of the Australian National Botanic Gardens in Canberra.

G. glauca F. Muell. var. glandulosa Benth., Fl. Austral. 4: $77(1868)=$ G. berardiana (Gaudich.) Carolin

Lectotype: New South Wales: Darling River, Dallachy (K). ParalectotyPe: Goyinga Mountains, Vict. Expl. Expedition (MEL 24170). The lectotype is the only specimen at $\mathrm{K}$ labelled var. glandulosa which has been annotated by Bentham. The only specimen at $\mathrm{K}$ from the Goyinga Mountains is a specimen of $\mathrm{G}$. fascicularis.

Calogyne linearis S. Moore, J. Linn. Soc., Bot. 45: 185 (1920) = G. berardiana (Gaudich.) Carolin

Lectotype: Western Australia: Kununoppin, Stoward 307 (BM). Paralectotype: Kauring, G. W. Brown ex herb. Stoward (BM).

\section{G. ochracea Carolin, sp. nov.}

Herba decumbens stolonifera. Folia oblanceolata 2-3 cm longa pubescentes fasciculata dentata pilis glandulosis et antrorso-simplicibus. Flores in racemis foliosis dispositi pedunculis $8-15 \mathrm{~mm}$ longis ebracteolatis pubescentibus glandulosis. Corolla ochracea 15-16 mm longa pubescens glandulose et simpliciter extus glabra intus sacco prominenti. Stylus bifidus. Capsula globula $6 \mathrm{~mm}$ diametro valvis duabus dehiscens. Semina orbiculata nigra reticulata ala angustissima straminea.

Holotype: Western Australia: Shark Bay, C.A. Gardner, Aug. 1932 (K).

Decumbent, stoloniferous herb to $15 \mathrm{~cm}$ long with a short stock. Leaves clustered near base of scapes on stolons or stock, oblanceolate, mostly $3-6 \mathrm{~cm}$ long, 4-8 $\mathrm{mm}$ wide, tapering very gradually into an indistinct petiole, dentate, glandular-pubescent, with some antrorse simple hairs on midvein on undersurface; a few smaller leaves present on scapes. Flowers in racemes often with zig-zag axis; bracts narrow-oblong to narrow-elliptic, 4-7 $\mathrm{mm}$ long, 1-2 $\mathrm{mm}$ wide, glandular-pubescent, dentate to entire; peduncles $8-15 \mathrm{~mm}$ long, glandular-pubescent, indistinctly articulate; bracteoles absent. Sepals narrowoblong to narrow-elliptic, 4-5 mm long, 1-1.5 mm wide, acute, entire, glandular-pubescent, adnate to ovary for $1 / 2-2 / 3$ its length. Corolla 'rich' yellow, 
15-16 mm long, glandular-pubescent, with some scattered simple hairs outside, almost glabrous inside, auriculate; anterior pocket prominent, as long as ovary or nearly so; tube c. $2 \mathrm{~mm}$ long; superior lobes narrow-oblong, c. $10 \mathrm{~mm}$ long, 1.5-2 $\mathrm{mm}$ wide; inferior lobes oblanceolate, $8-9 \mathrm{~mm}$ long, 2-2.5 mm wide with wings to $2 \mathrm{~mm}$ wide, c. $2 / 3$ as long as lobes; connate part of inferior lobes 4-5 mm long. Stamen filaments linear, c. $3 \mathrm{~mm}$ long; anthers oblong, $1.5 \mathrm{~mm}$ long. Ovary glandular-pubescent; septum scarcely $1 / 2$ as long as loculus; ovules 20; style bifid, c. $8 \mathrm{~mm}$ long, each branch (including indusium) c. $5 \mathrm{~mm}$ long; each half-indusium oblong, $1.5 \mathrm{~mm}$ long, with a \pm lateral orifice beset with palebrown bristles c. $0.2 \mathrm{~mm}$ long. Fruit globular, c. $6 \mathrm{~mm}$ diam., glandularpubescent, 2-valved to base. Seeds black, orbicular, c. $2 \mathrm{~mm}$ diam., reticulatefoveate, with a \pm distinct rim; wing c. $0.1 \mathrm{~mm}$ wide, brownish.

RANGE: Carnarvon area of Western Australia.

HABITAT: Sandy soil.

Discussion: The closest relative of this species is probably $G$. berardiana but it can be distinguished quite easily by the broader sepals, much more distinct anterior pocket of the corolla and the almost obsolete wing of the seed.

SPECIMENS EXAMINED: WeStern Australia: 7 miles $(11.2 \mathrm{~km}) \mathrm{N}$ of Quobba H.S., A.S. George 10159 (PERTH); $4 \mathrm{~km}$ N of Herald Bay outcamp, Dirk Hartog Island, A.S. George 11508 (PERTH).

The specific epithet refers to the colour of the corolla. Latin, ochraceus $=$ ochre yellow.

G. elongata Labill., Nov. Holl. Pl. 1: 52 (1804).

Lectotype: Western Australia: Habitat in Capite Van Diemen, Labillardière (P, donné par $M$. $W e b b$ ). ISOLECTOTYPE: BM, FI.*

G. salmoniana (F. Muell.) Carolin, comb. nov.

BASIONYM: Velleia salmoniana F. Muell., Victorian Naturalist 9: 127 (1892).

Holotype: Western Australia: Gascoyne River, Mrs Forrest, 1889 (MEL 9812). There are two specimens at MEL (see below) but only one bears the citation as given by Mueller (the collector having become Lady Margaret Forrest in the interval between collection and description).

Mueller, in placing this species in Velleia, was impressed by the sepals being almost free from the inner floral whorls. However, the inflorescence is clearly that of Goodenia and the corolla is adnate to the ovary. Moreover, there are a number of other Goodenia species in which the sepals are almost free from the ovary.

G. filiformis $R$. Br., Prodr.: 578 (1810).

Lectotype: Western Australia: Inter Princess Royal Harbour and Cape Howe, Prope Portum Regis Georgii III, R. Brown, 18 Dec. 1801 (BM). IsOleCtoTYPE: K.*

G. filiformis var. hirsuta K. Krause, Pflanzenr. 54: 86 (1912) = G. filiformis $R$. $\mathrm{Br}$.

Lectotype: Western Australia: Drummond 185 (K). Isolectotypes: BM, MEL 23640 , P.*

G. krauseana Carolin, nom. nov.

RePlaCed Name: G. nana K. Krause, Pflanzenr. 54: 80 (1912) non Vriese, Natuurk. Verh. Holl. Maatsch. Wetensch. Haarlem ser. 2 10: 132 (1854). 
G. concinna Benth., Fl. Austral. 4: 76 (1868).Lectotype: Western Australia:

Eyre's Relief, Maxwell (K). Isolectotype: (MEL 23674). ParalectotyPes: Drummond 360 (K); Point Henry, Oldfield (MEL); E. Mount Barren, Maxwell (K); Phillips and Fitzgeralds Ranges, Maxwell (K, MEL 23673).

G. micrantha Hemsley ex Carolin, nom. et stat. nov.

RePLACED NAME: G. filiformis var. minutiflora F. Muell. ex K. Krause, Pflanzenr. 54: 86 (1912). Mueller did not publish the varietal epithet. His statement in Fragm. 8: 245 (1874): 'G. filiformis nonnumquam varietatem minutifloram producit' is not a valid publication of this variety and therefore the first valid publication is due to Krause. Since Christensen and Ostenfeld, Vid. Selsk. Biol. Medd. 3: 124 (1921) refer only to Mueller's invalid statement when they rename it G. micrantha Hemsl. ined., their binomial is invalid.

G. havilandii Maiden \& Betche, Proc. Linn. Soc. New South Wales 38: 250 (1913) (as G. havilandi).

Lectotype: New South Wales: Cobar, F.E. Haviland, Sept. 1911 (NSW).

G. macroplectra (F. Muell.) Carolin, comb. nov.

Basionym: Velleia macroplectra F. Muell., Fragm. 12: 22 (1882). Symphyobasis macroplectra (F. Muell.) K. Krause, Pflanzenr. 54: 41 (1912)

LeCTOTYPE: WeStERn AuSTRALIA: Gascoyne River, $J$. Forrest (MEL). This is a similar case to that of $G$. salmoniana (see above) but, once again, the inflorescence is clearly that of Goodenia and the corolla is adnate to the top of the ovary. The recognition of the genus Symphyobasis makes the genus Goodenia paraphyletic (Carolin, unpub.).

G. nicholsonii F. Muell., Fragm. 1: 203 (1859). = G. cycloptera $R$. Br.

LeCTOTYPE: SOUth AuSTRALIA: NW interior of South Australia, Macdougall [sic] Stuart (MEL 23060 pro parte). ISOLECTOTYPE: K.* The sheet (MEL 23060) bears specimens of two entirely different species. Mueller's description applies only to the scraps of flowers, etc. on the right-hand side of the sheet. It seems probable that the best part of this specimen was retained at $\mathrm{K}$. The type of $G$. nicholsonii was probably collected on the same expedition as that of $G$. chambersii.

G. larapinta Tate in Spencer, Report on the work of the Horn Scientific Exploring Expedition to Central Australia 3: 189 (1896).

Lectotype: Northern Territory: Glen Edith, $R$. Tate, June 1894 (AD). ISOLECTOTYPES: K, MEL 23785.

G. odonnellii F. Muell., Australas. J. Pharm. 1: 278 (1886).

LeCTOTYPE: WeSteRn Australia: Ord River, O'Donnell (MEL). IsOlectotyPes: MEL. There are a number of sheets in MEL with this locality and I have marked one of them as the lectotype.*

\section{G. redacta Carolin, sp. nov.}

Herba ascendens vel decumbens caulibus pubescentibus molliter simpliciter ac minute glandulose usque ad $15 \mathrm{~cm}$ longis. Folia plerumque basalia ascendentes obovata $2.5-5 \mathrm{~cm}$ longa dentata obtusa pubescentia pilis simplicibus dispersis versus basim in petiolum indistinctum contracta. Flores in racemis foliosis terminalibus dispositi. Pedunculi $5-10 \mathrm{~cm}$ longi ebracteolati pubescentes pilis antrorsis simplicibus. Corolla flava $6-7 \mathrm{~mm}$ longa pubescens molliter simpliciter ac glandulose minime extus. Lobi superiores corollae exalati sed auriculati. Semina elliptica $3 \mathrm{~mm}$ longa reticulata brunnea sordide ala membranacea albida $0.2-0.4 \mathrm{~mm}$ lata. 
Holotype: Western Australia: Prince Regent River, Bradshaw \& Allen, 1891 (MEL 25769).

Ascending to decumbent herb with thin tap-root and very short stock. Stems terete, to $15 \mathrm{~cm}$ long, pubescent with soft antrorse simple hairs and some minute glandular ones. Basal leaves arranged in an ascending rosette, obovate, $2.5-5 \mathrm{~cm}$ long, $10-15 \mathrm{~mm}$ wide, tapering very gradually towards base into a \pm distinct petiole, dentate, with some soft scattered simple hairs especially on margins and lower surface of midrib; cauline leaves smaller and becoming almost sessile. Flowers in terminal leafy racemes; bracts leaf-like but smaller narrower and becoming almost sessile; peduncles 5-10 $\mathrm{mm}$ long, pubescent with soft antrorse simple hairs and some minute glandular ones, not distinctly articulate; bracteoles absent. Sepals unequal in size; posterior sepal elliptic, 2-3 times as long as others; anterior and lateral sepals elliptic-oblong, $1.5-2 \mathrm{~mm}$ long, 0.4-0.6 mm wide, acute, entire, pubescent with soft simple hairs and minute glandular ones, adnate to ovary for c. $3 / 4$ its length. Corolla yellow (?), 6-7 mm long, with soft simple and minute glandular hairs outside, \pm pubescent towards base inside; anterior pocket almost obsolete; tube c. $0.8 \mathrm{~mm}$ long; superior lobes narrow-oblong to almost linear, $2-2.5 \mathrm{~mm}$ long, $0.2-0.4 \mathrm{~mm}$ wide, tapering towards an acute point; inferior lobes ovate-oblong, $2.5 \mathrm{~mm}$ long, $1 \mathrm{~mm}$ wide; wings on superior lobes almost obsolete except for a distinct barbulate auricle, those on inferior lobes to $1 \mathrm{~mm}$ wide, $1 / 2-2 / 3$ as long as lobe; connate part of inferior lobes $2.5-3 \mathrm{~mm}$ long. Stamen filaments linear, c. 0.8 $\mathrm{mm}$ long; anthers oblong, c. $0.6 \mathrm{~mm}$ long. Ovary pubescent; septum scarcely $1 / 3$ as long as loculus; ovules $6-10$; style c. $1.5 \mathrm{~mm}$ long, glabrous or nearly so; indusium very broad-obovate, $0.8 \mathrm{~mm}$ long, $0.8 \mathrm{~mm}$ wide, purplish with a few scattered hairs particularly at base on lower surface, biconvex, with a concave orifice beset with purplish bristles c. $0.2 \mathrm{~mm}$ long. Fruit globular, 3-6 mm diam., pubescent, 2-valved usually not quite to base. Seeds flat, greyish brown, elliptic, $3 \mathrm{~mm}$ long, $2.5 \mathrm{~mm}$ wide, reticulate-foveate, with a prominent rim; wing $0.2-0.4 \mathrm{~mm}$ wide, white, membranous.

RANGE: Gardner (Kimberley) District of Western Australia and Darwin-Gulf District of Northern Territory.

HABITAT: Woodlands and open communities.

Discussion: The indumentum and seeds place this species fairly close to $G$. odonnellii F. Muell., but it is easily distinguished by the enlarged posterior sepal and the reduced superior corolla-lobes which bear scarcely any wings but for the auricle.

Selected Specimens (7): Western Australia: Bindelong Creek, E.M. Bennet 1777, 19 May 1967 (PERTH); $9 \mathrm{~km} \mathrm{~N}$ of Drysdale Stn., D.E. Symon 7090, 28 May 1971 (AD).

Named from the reduced superior lobes of the corolla. Latin, redactus $=$ reduced.

G. cirrifica F. Muell., Australas. J. Pharm. 1: 81 (1886).

LECTOTYPE: NORTHERN TERRITORY: On the Alligator River, Moritz Holtze (MEL 23683). ISOLECTOTYPES: K, MEL 23684, NT 24267 (a fragment).* There are two sheets of this species at MEL which were collected by Holtze; only one is labelled 'Alligator River', and this is selected as the lectotype.

G. armitiana F. Muell., Fragm. 10: 110 (1877).

Lectotype: QueEnSLAnd: Einasleigh River, Armit 466 (MEL 23695). ParalectotyPe: Tait River, Gilbert River, Lynd River, Armit (MEL23686). Only the paralectotype bears 
the label 'Lynd River' - cited by Mueller as such in his original description. Unfortunately, it does not agree with Mueller's description in that the glandular hairs are not apparent. Furthermore, the label also bears the localities 'Tait [sic] River, Gilbert River' in addition to Lynd River. There is only one specimen on the sheet. These localities thus cover a very large area and included between the Lynd and the Gilbert Rivers is the Einasleigh River (a tributary of the Gilbert), the locality of another Armit specimen which does agree with the description. It seems that Mueller had no clear idea of the locality of MEL 23686 and there is no reason for accepting it as a holotype merely because it bears the same locality as his citation, especially since it also bears other localities. In fact it must be rejected since it does not agree with the description. MEL 23695 from Einasleigh River bears the name ' $G$. armittiana' [sic] in Mueller's handwriting and since it comes from the same area as designated by Mueller, I am selecting it as the lectotype.

G. linifolia W. Fitzg., J. \& Proc. Roy. Soc. Western Australia 3: 213 (1918).

Lectotype: Western Australia: Inglis Gap, W.V. Fitzgerald (K). Paralectotypes: Inglis Gap, King Leopold Ranges, W.V. Fitzgerald (NSW); Lennard River, W.V. Fitzgerald (NSW); Isdell River, W.V. Fitzgerald (NSW); Barnett River, W.V. Fitzgerald (NSW).

G. nuda E. Pritzel, Bot. Jahrb. Syst. 35: 562 (1905).

Holotype: Western Australia: Bei Spring Station, $55 \mathrm{~km}$ südlich von Roeburne, Diels 2792, April 1901 (B, destroyed). NEOTYPE: 96 miles $(153.6 \mathrm{~km})$ from Onslow on $\mathrm{Mt}$ Stuart Road, R.C. Carolin 7788, 10 Aug. 1970 (NSW). IsOTYPE: SYD.

\section{G. pallida Carolin, sp. nov.}

Herba ascendens ad $50 \mathrm{~cm}$. Folia caulina anguste elliptica $5-7 \mathrm{~cm}$ longa crassa glauca dentata vel integra sessilia glabra. Flores in racemis brevibus vel umbellis dispositi. Pedunculi articulati ebracteolati pilis simplicibus ac glandulosis. Sepala lineari-deltoidea $1.5-2 \mathrm{~mm}$ longa. Corolla violacea pallide 14-16 mm longa pilis simplicibus ac glandulosis extra. Semina orbicularia biconvexa $4-4.5 \mathrm{~mm}$ in diametro brunnea reticulata ala membranacea fulva $\mathrm{c}$. $1 \mathrm{~mm}$ lata.

Holotype: Western Australia: 127 miles $(203 \mathrm{~km}$ ) from Onslow on Roeburne road, R.C. Carolin 7845, 11 Aug. 1970 (NSW). ISOTYPE: SYD.

Herb with mostly cauline leaves. Stems to $50 \mathrm{~cm}$ long, pubescent when young with short patent simple hairs and brown-headed glandular hairs, glabrescent. Leaves thick, glaucous, narrow-elliptic, 5-7 cm long, 3-8 $\mathrm{mm}$ wide, tapering very gradually towards base, acute, dentate with narrow teeth or entire. Flowers in short terminal racemes or umbels; bracts linear, 3-6 mm long, $0.2-0.8 \mathrm{~mm}$ wide, entire, glandular- and simple-pubescent, with a prominent axillary tuft of white hairs; peduncles 3-4 cm long, glandular- and simple-pubescent, distinctly articulate 1-2 mm below ovary. Sepals linear-deltoid, 1.5-2 mm long, 0.2-0.3 $\mathrm{mm}$ wide, acute, entire, glandular- and simple-pubescent, adnate to ovary for $1 / 2$ its length. Corolla pale purple, 14-16 mm long, glandular- and simplepubescent outside, with simple hairs scattered over inside in throat and tube, auriculate; anterior pocket obscure, c. $1 / 2$ as long as ovary; tube $2-2.5 \mathrm{~mm}$ long; superior lobes narrow-oblong-lanceolate, $7.5-8 \mathrm{~mm}$ long, 1.5-1.8 mm long; inferior lobes narrow-oblong, 6-6.5 mm long, $1.5 \mathrm{~mm}$ wide; wings to $2 \mathrm{~mm}$ wide, $1 / 2-2 / 3$ as long as lobe; connate part of inferior lobes $5-6 \mathrm{~mm}$ long. Stamen filaments linear, $2.5 \mathrm{~mm}$ long; anthers oblong, $1.5 \mathrm{~mm}$ long. Ovary glandularand simple-pubescent; septum c. 1/2 as long as loculus; ovules 15-20; style $4 \mathrm{~mm}$ long, glabrous; indusium transverse-ovate, $1.2 \mathrm{~mm}$ long, $1.2 \mathrm{~mm}$ wide, brownish, with a few scattered simple hairs towards base, with a slightly concave 
orifice beset with white silky bristles c. $0.3 \mathrm{~mm}$ long. Fruit subglobular, $6-7 \mathrm{~mm}$ diam., pubescent, 2-valved eventually to base. Seeds flat, dark brown, orbicular, 4-4.5 mm diam., reticulate-alveolate, with a distinct rim; wing 1-1.2 mm wide, yellowish brown, membranous.

RANGE: Known only from the type collection.

Habitat: Annual grassland in Acacia woodland.

Discussion: This is a distinct species differing from $G$. nuda, which is possibly its nearest relative, both in the indumentum and flower color.

The specific epithet refers to the pallid purple color of the corolla. Latin, pallidus $=$ pallid.

\section{G. prostrata Carolin, sp. nov.}

Herba prostrata caulibus simpliciter ac glandulose sparse pubescentibus sed glabrescentibus usque $30 \mathrm{~cm}$ longis. Folia basalia oblanceolata usque obovata 2-4 cm longa crassa dentata glabra vel sparsissime pubescentia versus basim in petiolum indistinctum contracta et in rosula disposita. Folia caulina parviora caespitis distinctissimis pilorum villosorum albidorum in axillis. Flores pedunculis $10-25 \mathrm{~mm}$ longis pubescentibus simpliciter et glandulose articulatis ebracteolatis in racemis foliosis terminalibus dispositi. Corolla flava signis brunneis in fauce 12-15 mm longa pubescens simpliciter ac glandulose extus. Semina elliptica $3 \mathrm{~mm}$ longa reticulata brunnea ala angusta brunnea mucilaginea.

Holotype: Western Australia: 22 miles $(35.2 \mathrm{~km}$ ) from Roy Hill on Wittenoom road, R.C. Carolin 7702, 7 Aug. 1970 (NSW). IsOTYPE: SYD.

Prostrate herb with a narrow tap-root and a short sometimes branched stock. Stems terete or ridged, to $30 \mathrm{~cm}$ long, with scattered simple hairs and some glandular and multicellular hairs especially in younger stages. Basal leaves \pm thick, oblanceolate to obovate, $2-4 \mathrm{~cm}$ long, $5-10 \mathrm{~mm}$ wide, tapering gradually towards base into an indistinct petiole, dentate, glabrous or with a very few simple hairs, with a prominent tuft of white villous axillary hairs; cauline leaves similar but usually less dentate, smaller and narrower. Flowers in terminal racemes or umbels leafy at base; bracts similar to upper leaves; peduncles 10-25 mm long, pubescent with simple and glandular hairs, indistinctly articulate just below ovary; bracteoles absent. Sepals narrow-elliptic to ellipticlanceolate, c. $2.5 \mathrm{~mm}$ long, $0.5-0.7 \mathrm{~mm}$ wide, acute, entire, simple- and glandular-pubescent, adnate to ovary for c. $1 / 2$ its length. Corolla yellow with brownish markings in throat, $12-15 \mathrm{~mm}$ long, densely pubescent outside with simple and glandular hairs, pubescent inside below throat and extending upwards along lines of connation, auriculate; anterior pocket distinct, as long as ovary or nearly so; tube 1.5-2 mm long; superior lobes narrow-oblong, 7-8 mm long, 0.8-1.2 mm wide; inferior lobes oblong-ovate, $4.5-5 \mathrm{~mm}$ long, $1-1.2 \mathrm{~mm}$ wide; wings to $3 \mathrm{~mm}$ wide, as long as lobe; connate part of inferior lobes 4.5-5.5 mm long. Stamen filaments linear, c. $2 \mathrm{~mm}$ long; anthers narrowoblong, $1 \mathrm{~mm}$ long. Ovary glandular- and simple-pubescent; septum $<1 / 3$ as long as loculus; ovules $8-12$; style c. $3 \mathrm{~mm}$ long, with some scattered villous hairs especially towards top; indusium transverse-oblong to transverse-ovate, 1 $\mathrm{mm}$ long, $2 \mathrm{~mm}$ wide, brownish, villous on both sides, with a slightly longer beard on lower surface, with a slightly curved orifice beset with white bristles to $0.4 \mathrm{~mm}$ long on upper lip and slightly shorter ones on lower lip. Fruit globular, only slightly compressed, 4-5 mm diam., glandular- and simple-pubescent, 
2-valved to base, each valve entire. Seeds flat, brown, elliptic, $3 \mathrm{~mm}$ long, $2 \mathrm{~mm}$ wide, reticulate-alveolate, with a prominent rim; wing $0.2 \mathrm{~mm}$ wide, brownish, mucilaginous.

RANGE: Keartland, Fortescue, Ashburton and Carnarvon Districts of Western Australia.

HABITAT: Acacia scrubs on red sandy soil.

Discussion: This species is very close to $G$. muelleriana, from which it can be distinguished by the prostrate habit, the almost glabrous mature leaves, the narrower mucilaginous wing on the seed and the very short ovary and fruit septum.

Selected Specimens (14): Western Australia: 11 miles $(17.6 \mathrm{~km}) \mathrm{N}$ of Roy Hill, A.C. Beauglehole 11401, 12 Aug. 1965 (SYD); Railway Crossing of Tom Price-Dampier railway and road from Wittenoom to Tom Price, R.C. Carolin 7753, 9 Aug. 1970 (SYD); c. $28 \mathrm{~km} \mathrm{NE}$ of Mt. Newman, A.C. Beauglehole 48957, 19 Aug. 1974 (SYD).

Named from the prostrate habit. Latin, prostratus $=$ prostrate.

\section{G. muelleriana Carolin, sp. nov.}

Herba ascendens vel erecta usque $40 \mathrm{~cm}$ caulibus pubescentibus simpliciter ac glandulose. Folia basalia elliptico-oblanceolata 3-6 cm longa, 8-20 mm lata dentata vel fere integra sparse pubescentia versus basim sensim contracta caespitis pilorum villosorum in axillis. Flores pedunculis sparse pubescentibus simpliciter ac glandulose articulatis ebracteolatis $20-35 \mathrm{~mm}$ longis in racemis terminalibus dispositi bracteis foliosis versus basim racemi sed minoribus et angustioris versus apicem. Pili glandulosi capitibus prominentibus brunneis multicellularibus. Corolla flava, signis brunneo-purpurescentibus in fauce 12-15 mm longa pubescens simpliciter ac glandulose extus et pubescens intus. Semina orbicularia $2.6-3 \mathrm{~mm}$ diametro ala sordida $1 \mathrm{~mm}$ lata.

Holotype: Western Australia: 40 miles $(64 \mathrm{~km})$ from Tom Price on Wittenoom road, R.C. Carolin, 7761, 9 Aug. 1970 (NSW). IsOTYPE: SYD.

Ascending to erect herb with a narrow tap-root and a short often branched stock. Stems terete or ridged, to $40 \mathrm{~cm}$ high, \pm pubescent with scattered simple hairs and glandular hairs with multicellular heads. Basal leaves ellipticoblanceolate, 3-6 cm long, 8-20 mm wide, tapering very gradually towards base into an indistinct petiole, dentate to almost entire, with scattered simple and glandular hairs and a tuft of villous axillary hairs; cauline leaves smaller narrower and less dentate. Flowers in a terminal raceme; bracts at base similar to leaves, becoming progressively smaller and more linear towards top; peduncles $20-35 \mathrm{~mm}$ long with scattered simple and glandular hairs, articulate just below ovary; bracteoles absent. Sepals narrow-lanceolate-oblong, c. $2 \mathrm{~mm}$ long, $0.2-0.3 \mathrm{~mm}$ long, acute, pubescent with simple and glandular hairs, adnate to ovary for $1 / 2-2 / 3$ its length. Corolla yellow, $12-15 \mathrm{~mm}$ long, with brownish or purplish brown markings in throat, pubescent outside with glandular and simple hairs and pubescent inside below throat with hairs extending upwards along lines of connation, auriculate; anterior pocket distinct, $2 / 3$ to equally as long as ovary; tube $2-3 \mathrm{~mm}$ long; superior lobes narrow-oblonglanceolate, 8-9 mm long, 1.2-1.5 mm long; inferior lobes ovate-oblong, 3.5-4 $\mathrm{mm}$ long, c. $1.5 \mathrm{~mm}$ wide; wings to $3 \mathrm{~mm}$ wide, $1 / 2-2 / 3$ as long as lobes; connate part of inferior lobes 5-6 mm long. Stamen filaments linear, 2-3 mm long; anthers narrow-oblong $1.5 \mathrm{~mm}$ long. Ovary pubescent with glandular and simple hairs; septum c. $2 / 3$ as long as loculus; ovules $12-16$; style $4-5 \mathrm{~mm}$ long with a very few villous hairs towards top; indusium transverse-ovate to 
transverse-oblong, $1 \mathrm{~mm}$ long, c. $2.5 \mathrm{~mm}$ wide, brownish, villous hairs scattered over upper surface and a thin villous beard on lower surface, with a slightly curved orifice beset with white bristles to $0.5 \mathrm{~mm}$ long on upper lip and shorter ones on lower lip. Fruit simple- and glandular-pubescent, globular often slightly compressed, c. $6 \mathrm{~mm}$ diam., 2-valved to base and each valve remaining entire. Seeds flattened, dark grey, orbicular, $2.6-3 \mathrm{~mm}$ wide, colliculate with a prominent rim; wing $1 \mathrm{~mm}$ wide, thin dark, grey.

RANGE: Keartland, Fortescue and Canning Districts of Western Australia.

HABITAT: Shrub woodlands and Triodia grasslands.

Discussion: This species was previously included under $G$. forrestii and is distinguished from it primarily by the much less dense indumentum.

Selected Specimens (17): Western Australia: 56 miles $(89.6 \mathrm{~km})$ from Port Hedland on Broome road, R.C. Carolin 7593, 4 Aug. 1970 (SYD); 46 miles $(73.6 \mathrm{~km}$ ) from Marble Bar on Nullagine road, R.C. Carolin 7688, 6 Aug. 1970 (SYD); 96 miles (153.6 $\mathrm{km}$ ) from Onslow on Mt Stuart road, R.C. Carolin 7787, 10 Aug. 1970 (SYD); 74 miles $(118.4 \mathrm{~km})$ from Tom Price on Yampire Gorge road, R.C. Carolin 7771, 9 Aug. 1970 (SYD).

Named for Ferdinand von Mueller who described so many Goodenia species and who, for many years in the last century, was Government Botanist in Victoria.

G. forrestii F. Muell., Victorian Naturalist 9: 58 (1892) (as G. foresti).

LeCTOTYPE: WeStern Australia: Part of the specimen 'Yule-Fortescue and Sherlock Rivers, Hon. Sir John Forrest' (MEL). ISOLECTOTYPE: ?K.

There are two elements amongst the specimens cited by Mueller under this species name: one is the present species and the other is G. muelleriana Carolin. Moreover, Mueller's type description is cast to cover both elements and it is quite impossible to choose which element corresponds more closely to it. Since one must be selected as the lectotype, I am choosing the part corresponding to the present species as being current usage (Int. Code of Botanical Nomenclature recommendation).

G. cusackiana (F. Muell.) Carolin, comb. nov.

BasionYm: Velleia cusackiana F. Muell., Victorian Naturalist 12: 124 (1896). As in the case of $G$. salmoniana, Mueller was impressed here by the sepals being almost free from the ovary but this species has none of the other characteristics of Velleia. In particular the inflorescence is clearly that of a Goodenia.

G. sepalosa F. Muell. ex Benth., Fl. Austral. 4: 72 (1869).

LeCTOTYPE: WeSTERn Australia: Camden Harbour, Martin (K). IsOleCtOTYPE: possibly MEL 23753 but no collector named on label. PARALECTOTYPES: NW Coast, Bynoe (MEL); Port Essington, Armstrong (MEL). Of the three specimens cited by Bentham, the Armstrong collection from Port Essington belongs to a species in series Calogyne, the Bynoe collection has practically sessile leaves and the one from Camden Harbour is the only one bearing the name in Mueller's handwriting and corresponding to the protologue. This is therefore selected as the lectotype.

G. sepalosa var. glandulosa Carolin, var. nov.

Differt ab typo indumento glanduloso.

Holotype: Western Australia: 9 miles (14.4 km) S. of Derby, N. Byrnes, 24 May 1967 (NT 14200).

Differs from the type variety in that most of the hairs are glandular whilst in the type variety they are simple and coarse. 
RANGE: Known only from the type collection.

HABITAT: Acacia woodlands.

The varietal epithet refers to the glandular indumentum. Latin, glandulosus = glandular.

G. arachnoidea Carolin, sp. nov.

Herba erecta vel ascendens. Folia basalia obovata 4-10 cm longa dentata obtusa petiolata pilis rigidis arcuatis instructa. Folia caulina ovata vel elliptica plus minusve similis foliis basalibus. Pedunculi ebracteolati pilis simplicibus retrorsis et arachnoideis confertis instructi. Corolla lutea 12-14 mm longa pilis arachnoideis simplicibusque extra. Capsula obovoidea $4-5 \mathrm{~mm}$ longa. Semina elliptica vel late elliptica $4 \mathrm{~mm}$ longa plana ochracea nitida.

HolotyPe: Western AuStralia: $8 \mathrm{~km}$ SW of Theda Stn., Kimberleys, D. Symon 7101, 29 May 1971 (AD). ISOTYPES: SYD, PERTH.

Erect to ascending herbs to $45 \mathrm{~cm}$ tall. Stems terete, pubescent with stiff retrorse simple hairs and arachnoid hairs. Basal leaves obovate, 4-10 cm long, $1.5-3.5 \mathrm{~cm}$ wide, tapering towards base into a distinct petiole, obtuse or with a tooth at apex, dentate, pubescent with stiff arcuate hairs on both surfaces; cauline leaves ovate to elliptic, smaller. Flowers in terminal and axillary racemes; bracts elliptic at base to linear near top of raceme, $1-2.5 \mathrm{~cm}$ long, $1-4$ $\mathrm{mm}$ wide, sessile or tapering to a short petiole, acute, dentate, pubescent; peduncle to $4 \mathrm{~cm}$ long, always longer than bract, pubescent with retrorse simple hairs which are obscured by dense arachnoid hairs when young, articulate just below ovary. Sepals linear-deltoid, 2-5 mm long, $0.3-0.5 \mathrm{~mm}$ wide, entire, arachnoid-pubescent and with a few stiff simple hairs at apex, adnate to ovary for $3 / 4$ its length or more. Corolla yellow, 12-14 mm long, pubescent with arachnoid and stiff simple hairs outside, pubescent inside with short simple hairs becoming denser towards base and there forming a \pm complete ring, auriculate; anterior pocket obscure, scarcely $1 / 4$ as long as ovary; tube $1-1.5 \mathrm{~mm}$ long; superior lobes narrow-oblong, $6-7 \mathrm{~mm}$ long, $0.7-0.8 \mathrm{~mm}$ wide; inferior lobes oblong, 4-5 mm long, $1.5 \mathrm{~mm}$ wide; wings to $1.5 \mathrm{~mm}$ wide, almost as long as lobe. Stamen filaments linear, 2-2.5 mm long; anthers oblong, $1 \mathrm{~mm}$ long. Ovary arachnoid and simple pubescent; septum very short; ovules 5-6; style 4-4.5 mm long, glabrous or with very few simple hairs; indusium broadovate, $1 \mathrm{~mm}$ long, $1 \mathrm{~mm}$ wide, brownish, glabrous on upper surface, with a few long stiff white hairs on lower surface, with an almost straight orifice beset with white bristles c. $0.1 \mathrm{~mm}$ long on both lips. Fruit obovoid, $4-5 \mathrm{~mm}$ long, $0.3 \mathrm{~mm}$ wide, pubescent, 2-valved almost to base. Seed biconvex, brownish yellow, elliptic to broad-elliptic, $4 \mathrm{~mm}$ long, 2-2.5 $\mathrm{mm}$ wide, glossy, obscurely verrucate and thus the reticulate pattern showing more clearly; wing c. $0.1 \mathrm{~mm}$ wide.

RANGE: Gardner (Kimberley) District of Western Australia.

HABITAT: Woodland, mostly on sandstone.

DisCUSSION: A distinct species rather difficult to place but apparently close to the $G$. sepalosa group of species; the arachnoid indumentum distinguishes it.

Specimens Examined (7): Western Australia: Base of Anjo Peninsula, east of Vansittart Bay, E.A. Chesterfield 303, 22 May 1984 (SYD, MEL); $9 \mathrm{~km} \mathrm{SW}$ of Amax Basecamp, Mitchell Plateau, K.F. Kenneally 7137, 9 Feb. 1979 (SYD, PERTH); King Edward River, c. $50 \mathrm{~km}$ NE of Mitchell River HS., E.G. Errey \& A.C. Beauglehole 2853, 25 Aug. 1978 (SYD); Longini Landing, Kalumburu Mission, D.E. Symon 7112, 30 June 1972 (AD, SYD) 
The specific epithet refers to the appearance of the indumentum. Latin, arachnoideus $=$ cobwebby.

G. brachypoda (F. Muell. ex Benth.) Carolin, comb. et stat. nov.

BASIONYM: G. sepalosa var. brachypoda F. Muell. ex Benth., Fl. Austral. 4: 72 (1869).

\section{G. leiosperma Carolin, sp. nov.}

Herba ascendens vel decumbens hispida pilis simplicibus grossis et glandulosis minutis. Caules usque $60 \mathrm{~cm}$ longi. Folia basalia ovata vel oblongo-elliptica usque anguste oblonga vel lanceolata $5-10 \mathrm{~cm}$ longa dentata sessilia saepe auriculata ad basim. Flores pedunculis $4-10 \mathrm{~cm}$ longis ebracteolatis non articulatis in racemis foliosis terminalibus dispositi. Corolla flava $15-20 \mathrm{~mm}$ longa hispido-pubescens extus pubescens intus. Capsula globosa circa $8 \mathrm{~mm}$ diametro duabus valvis hiantibus dehiscens. Semina elliptica $2.5-3.5 \mathrm{~mm}$ longa laevia nitentia fulvo-straminea ora prominenti sed ala ad hilo restricta.

Holotype: NORThern Territory: 39 miles $(62.4 \mathrm{~km}) \mathrm{S}$ of Darwin, G. Chippendale, 18 March 1961 (NT 7776).

Ascending to decumbent short-lived herb with thin tap-root, hispid with long usually patent or spreading coarse simple hairs. Stems several, branched near base, slightly compressed or ridged towards top, to $60 \mathrm{~cm}$ long. Leaves basal and cauline but basal rosette very ephemeral; lower leaves ovate or oblongelliptic to narrow-oblong or lanceolate, $5-10 \mathrm{~cm}$ long, mostly $13-20 \mathrm{~mm}$ wide, sessile, often auriculate at base, dentate; upper leaves more distinctly auriculate and smaller; basal leaves usually tapering very gradually towards base. Flowers in terminal leafy racemes; bracts leaf-like but smaller; peduncles $4-10 \mathrm{~cm}$ long, pubescent-hispid with long spreading and shorter simple hairs and minute glandular ones visible with magnification, not articulate; bracteoles absent. Sepals linear to linear-lanceolate, 5-6.5 mm long, $0.5-0.8 \mathrm{~mm}$ wide, acute, ciliate, adnate to ovary for c. $2 / 3$ its length. Corolla yellow, $15-20 \mathrm{~mm}$ long, pubescent with long simple hairs and minute glandular ones outside, pubescent inside especially in depression formed by anterior petal in upper part of connate part of inferior lobes, wrinkled or with enations in connate part of inferior lobes, auriculate; anterior pocket obscure, scarcely $1 / 2$ as long as ovary; tube 4-6 mm long; superior lobes falcate-narrow-elliptic, $10-11 \mathrm{~mm}$ long, 2-2.3 mm wide; inferior lobes oblong to elliptic-ovate, $6-7.5 \mathrm{~mm}$ long, $2.3-2.8$ $\mathrm{mm}$ wide, anterior lobe sometimes slightly larger than anterior-lateral ones; wings $2 \mathrm{~mm}$ wide, dentate; connate part of inferior lobes $8-10 \mathrm{~mm}$ long. Stamen filaments linear, 3.5-4 mm long; anthers oblong, $2 \mathrm{~mm}$ long. Ovary pubescent-hirsute; septum scarcely $1 / 3$ as long as loculus; ovules 10-15; style $7.5-8.5 \mathrm{~mm}$ long, villous-pubescent towards top; indusium depressed-obovate, $2 \mathrm{~mm}$ long, $4.5 \mathrm{~mm}$ wide, convex with a straight orifice beset with white bristles c. $0.5 \mathrm{~mm}$ long on upper lip and much shorter ones on lower lip. Fruit globular, c. $8 \mathrm{~mm}$ diam., hirsute, 2-valved to base, gaping. Seeds flat, elliptic, 2.5-3.5 $\mathrm{mm}$ long, 1.8-2.2 $\mathrm{mm}$ wide, smooth, glossy, with prominent raised rim; wing absent except near hilum.

RANGE: Victoria River and Darwin-Gulf Districts of Northern Territory.

HABITAT: Sclerophyll forests and woodlands.

Discussion: This species is distinguished from its closest relative, G. hispida, with which it has been confused in the past, by the smooth seeds, the dense pubescence on the anterior corolla-lobe where it fuses with the other inferior lobes and the shorter ovary and more globular fruit. One specimen which I 
have referred here, $N$. Byrnes NB666 (NT 14382) from Litchfield Station, has almost glabrous stems, glabrescent leaves and lacks the dense pubescence inside the corolla. When more collections are available for study this may prove to be distinct.

Selected Specimens (29): Northern Territory: 13 miles $(20.8 \mathrm{~km}) \mathrm{S}$ of Darwin, $G$. Chippendale, 25 May 1958 (NT 4452); Fogg Dam area, G. Chippendale, 18 May 1959 (NT 6207); 2.7 miles $(4.3 \mathrm{~km}) \mathrm{W}$ of Burrundie, G. Chippendale, 16 March 1961 (NT 7649); McMinns Lagoon, M. Holtze, 1896 (MEL 23820); 5 miles (8 km) SW of Grove Hill, G. Chippendale, 17 March 1961 (NT 7669).

The specific epithet refers to the smooth seed. Greek, leios $=$ smooth, sperma $=$ seed.

\section{G. durackiana Carolin, sp. nov.}

Herba erecta vel decumbens. Caules usque $50 \mathrm{~cm}$ longi porcati pilis dispersis grossis simplicibus saepe retrorsis. Folia caulina elliptica vel oblonga 3-6 cm longa dentata acuta pilis dispersis saepe glabrescentia auriculata ad basim sessilia. Flores in racemis terminalibus foliosis dispositi. Pedunculi $2-5 \mathrm{~cm}$ longi ebracteolati non articulati pilis simplicibus in pagina adaxiali versus apicem. Corolla flava circa $15 \mathrm{~mm}$ longa fere glabra extus. Capsula globosa 8-10 mm diametro duabus valvis integris hiantibus dehiscens. Semina orbicularia 3-3.5 mm diametro laevia impolita ora prominenti sed sine ala.

Holotype: Western Australia: Kimberley Research Station, M. Lazarides 6743, 6 March 1963 (PERTH). ISOTYPE: CANB 123774.

Short-lived herb with a tap root and ephemeral basal leaf-rosette. Stems erect to decumbent, to $50 \mathrm{~cm}$ long, ridged, with scattered coarse often retrorse simple hairs. Leaves mostly cauline, elliptic to oblong, $3-6 \mathrm{~cm}$ long, $1-2.5 \mathrm{~cm}$ wide, \pm auriculate at base with a distinct very short petiole or sessile, coarsely dentate, with scattered coarse simple hairs, often glabrescent. Flowers in terminal leafy racemes; peduncles $2-5 \mathrm{~cm}$ long with coarse simple hairs on adaxial surface near top, not articulate, diverging particularly in fruiting stage. Sepals narrowelliptic, c. $7 \mathrm{~mm}$ long and $2 \mathrm{~mm}$ wide, acute, often dentate towards base, ciliate, with a few scattered coarse simple hairs towards margin, adnate to ovary for $2 / 3-3 / 4$ its length. Corolla yellow, c. $15 \mathrm{~mm}$ long, almost glabrous outside but sometimes with a few long simple hairs, pubescent inside particularly in throat, auriculate; anterior pocket almost obsolete; tube c. $5 \mathrm{~mm}$ long; superior lobes narrow-oblong-falcate c. $7 \mathrm{~mm}$ long and $1 \mathrm{~mm}$ wide; inferior lobes narrowoblong, c. $5 \mathrm{~mm}$ long and $1.5 \mathrm{~mm}$ wide; wings to $1.5 \mathrm{~mm}$ wide, as long as inferior lobe, c. $2 \mathrm{~mm}$ long on superior lobes; connate part of inferior lobes c. 6 $\mathrm{mm}$ long. Stamen filaments linear, c. $2 \mathrm{~mm}$ long; anthers narrow-oblong, c. 1.5 $\mathrm{mm}$ long. Ovary hirsute; septum c. $1 / 3$ as long as loculus; ovules 20-30; indusium depressed obovate, convex, $1 \mathrm{~mm}$ long, $4 \mathrm{~mm}$ wide, with some simple hairs, with a \pm convex orifice beset with white bristles $\mathrm{c} .1 \mathrm{~mm}$ long on both lips. Fruit globular, 8-10 mm diam., hirsute, 2-valved to base, each valve entire, gaping. Seeds flat, brown-yellow, orbicular, 3-3.5 mm wide, smooth but dull, with a fairly prominent rim; wing obsolete.

RANGE: Gardner (Kimberley) District of Western Australia.

HABITAT: Grasslands on black cracking soils.

Discussion: This species differs from the other species grouped around $G$. sepalosa in having smooth, dull seeds. It is possibly closest to $G$. byrnesii, from which it differs in the smooth seeds, broader sepals and the hairs on the 
peduncle almost restricted to the adaxial side. From $G$. sepalosa it differs in the coarser and less dense indumentum as well as the smooth seeds.

Specimen Examined: Western Australia: Ord River, K.M. Durack, 4 May 1945 (PERTH).

Named after the collector of one of the specimens cited here, who is the author of 'Kings in Grass Castles'.

\section{G. byrnesii Carolin, sp. nov.}

Herba decumbens vel prostrata. Folia basalia fugacia autem caulina ovatooblonga vel anguste oblonga $2-6 \mathrm{~cm}$ longa prasina sessilia auriculata dentata pilis paucissimis simplicibus. Pedunculi ebracteolati pilis simplicibus paucis instructi. Sepala anguste oblongo-elliptica 5-6 mm longa. Corolla lutea 17-20 $\mathrm{mm}$ longa. Capsula subglobosa $4-5 \mathrm{~mm}$ in diametro per duas valvas hiantes ad basim dehiscentia. Semina fulva plana elliptica $4 \mathrm{~mm}$ longa verrucosa.

Holotype: NORTHERN TERritory: 15 miles (24 km) SW of Elliott, N. Byrnes 1433, 12 March 1969 (NSW). ISOTYPE: SYD.

Decumbent to prostrate herb with thin taproot. Stems \pm ridged above but becoming terete below, to $30 \mathrm{~cm}$ long, sparsely pubescent-hirsute with coarse simple hairs. Basal leaves ephemeral, oblanceolate, $3-6 \mathrm{~cm}$ long, $6-10 \mathrm{~mm}$ long, pale green, tapering gradually towards base; cauline leaves ovate-oblong to narrow-oblong, mostly 4-6 cm long, 5-10 mm wide, sessile, \pm auriculate at base, dentate, sparsely villous-pubescent with coarse simple hairs. Flowers in terminal leafy racemes; bracts progressively smaller towards top; peduncles 3-5 $\mathrm{cm}$ long, with some scattered villous simple hairs, indistinctly articulate 2-3 $\mathrm{mm}$ below the ovary; bracteoles absent. Sepals narrow-oblong to elliptic, 5-6 $\mathrm{mm}$ long, $0.8-1 \mathrm{~mm}$ wide with some scattered coarse simple hairs especially on margins, acute, adnate to ovary for c. $2 / 3$ its length. Corolla yellow, 17-20 mm long, villous-pubescent outside with coarse simple hairs and some minute glandular ones, pubescent inside especially towards base, auriculate; anterior pocket almost obsolete; tube 3.5-4 mm long; superior lobes falcate-narrowoblong, 9-10 $\mathrm{mm}$ long, $1 \mathrm{~mm}$ wide; inferior lobes ovate, 6-7 $\mathrm{mm}$ long, 2.5-2.8 $\mathrm{mm}$ wide; wings c. $1.5 \mathrm{~mm}$ wide, dentate, c. $1 / 2$ as long as lobes; connate part of inferior lobes, 8-9 mm long. Stamen filaments linear, 3-4 mm long; anthers oblong, c. $1 \mathrm{~mm}$ long. Ovary villous-pubescent; septum scarcely $1 / 3$ as long as loculus; ovules c. 10; style 6-7 mm long, pubescent towards base; indusium transverse-oblong to depressed-obovate, $2 \mathrm{~mm}$ long, $4 \mathrm{~mm}$ wide, slightly convex above, glabrous or nearly so above, pubescent below, with an almost straight orifice beset with white hairs $0.5 \mathrm{~mm}$ long on upper lip and much shorter ones on lower lip. Fruit sub-globular, 4-5 mm diam., villous-hirsute, 2 -valved for $3 / 4$ its length, gaping, each valve entire. Seeds flat, greyish-yellow, elliptic, $4 \mathrm{~mm}$ long, $1.8 \mathrm{~mm}$ wide, verrucate and granulose, with a distinct rim; wing obsolete except close to hilum.

RANGE: Dampier and Gardner (Kimberley) Districts of Western Australia; Victoria River, Barkly Tablelands and Darwin-Gulf Districts of Northern Territory; Burke District of Queensland.

HABITAT: Blacksoil plains.

Selected Specimens (20): Western Australia: Bloodwood Creek, Mt Anderson, H.F. Broadbent 624, 28 Jan. 1953 (PERTH). NORTHERN TERRITORY: Leila Lagoon, R.C. Carolin 9294, 17 May 1974 (SYD); 42 miles $(67.2 \mathrm{~km})$ W of Wave Hill Police Stn., R.A. Perry 2278, 27 June 1949 (NT 18734); Powells Creek, M. Holtze 73, 1894 (MEL 22222). 
QueEnsLAND: Flinders River Lara Stn., Kennedy (MEL 23762); Saxby River Crossing on Wondoola Road, R.C. Carolin 8807, 22 April 1974 (SYD); 6 miles $(9.6 \mathrm{~km}) \mathrm{S}$. of Magoura, R.C. Carolin 8817, 23 April 1974 (SYD); Gregory Downs Road, R.C. Carolin 8872, 26 April 1974 (SYD).

Named for the collector of the holotype, who was a botanist in the Darwin Herbarium and subsequently at the Queensland Herbarium.

\section{G. campestris Carolin, sp. nov.}

Herba ascendens vel decumbens. Folia basalia fugacia autem caulina ovata ad lanceolata $1-7 \mathrm{~cm}$ longa dentata pilis paucis grossis simplicibus in marginibus atque pagina inferiora. Pedunculi glabri vel pilis paucissimis simplicibus ebracteolati. Corolla lutea $7-8 \mathrm{~mm}$ longa pilis simplicibus antrorsis extra. Capsula globosa vel ovoidea $5 \mathrm{~mm}$ longa per duas valvas hiantes ad basim dehiscentia. Semina plana elliptica $3.5 \mathrm{~mm}$ longa verrucosa.

HolOtYPE: NORTHERN TERRITORY: c. 35 miles $(56 \mathrm{~km}) \mathrm{S}$ of Timber Creek, R.C. Carolin 6667, 10 May 1968 (NSW). ISOTYPE: SYD.

Decumbent to ascending herb with thin taproot. Stems compressed or obscurely ridged above but becoming terete towards base, to $50 \mathrm{~cm}$ long, glabrous or nearly so. Leaves mostly cauline but with a few ephemeral basal leaves; basal leaves obovate-oblong $1-3 \mathrm{~cm}$ long, 4-10 mm wide, tapering very gradually towards base; cauline leaves ovate to lanceolate, $1-7 \mathrm{~cm}$ long, 5-10 mm wide, sessile, \pm auriculate at base, dentate, with very few coarse simple hairs especially on margins and lower surface of mid-rib. Flowers in terminal racemes; bracts leaf-like, progressively smaller towards top; peduncles $4-7 \mathrm{~cm}$ long, glabrous or with few short closely appressed simple hairs, very obscurely articulate 1-2 mm below ovary; bracteoles absent. Sepals lanceolate to narrowoblong, 1-2 mm long, $0.3-0.5 \mathrm{~mm}$ wide, with few coarse simple hairs particularly on margin, adnate to ovary for $3 / 4$ its length. Corolla yellow with purplish veins, 7-8 mm long, pubescent outside with antrorse simple and minute glandular hairs, pubescent inside towards base, wrinkled on connate part of inferior lobes, auriculate; anterior pocket scarcely $1 / 4$ as long as ovary; tube $2-2.5 \mathrm{~mm}$ long; superior lobes falcato-narrow-oblong, c. $4 \mathrm{~mm}$ long, 1-1.2 $\mathrm{mm}$ wide; inferior lobes ovate, $2 \mathrm{~mm}$ long, $1.2-1.5 \mathrm{~mm}$ wide; wings $1-2 \mathrm{~mm}$ wide, c. $1 / 2$ as long as lobes; connate part of inferior lobes c. $4 \mathrm{~mm}$ long. Stamen filaments 1.5-1.8 mm long; anthers oblong, $1.2 \mathrm{~mm}$ long. Ovary pubescent with coarse simple hairs; septum scarcely $1 / 4$ as long as loculus; ovules $6-8$; style $4 \mathrm{~mm}$ long, glabrous or nearly so; indusium transverse-oblong, $1 \mathrm{~mm}$ long, $2 \mathrm{~mm}$ wide, flat or slightly convex above, with few scattered hairs particularly on lower surface, with an almost straight orifice beset with long $(0.2 \mathrm{~mm})$ white bristles on upper lip and shorter ones on lower lip. Fruit globular-ovoid, $5 \mathrm{~mm}$ long, 3.5-4.5 mm wide, glabrescent 2-valved, entire, gaping. Seeds flat, yellowish, elliptic, $3.5 \mathrm{~mm}$ long, $1.5-1.8 \mathrm{~mm}$ wide, verrucate, granulose, with a prominent rim; wing almost obsolete.

RANGE: Gardner District (Kimberley) of Western Australia.

HABITAT: Grassy plains on black soils.

Discussion: This species is similar to $G$. hispida but differs in its habitat, the much smaller corolla, the inferior lobes which are shorter than the connate part of the inferior lobes, and in the very short septum of the fruit with many fewer seeds. 
Specimens EXamined: Northern Territory: Skull Creek, R.C. Carolin 6659, 10 May 1968 (SYD); 5 miles $(8 \mathrm{~km}$ ) W of Victoria River Crossing, N. Byrnes NB740, 10 May 1968 (NT 14575, NSW 87995).

Named for the open grassy plains in which this species grows. Latin, campestris $=$ pertaining to plains.

\section{G. malvina Carolin, sp. nov.}

Herba decumbens vel prostrata. Folia basalia fugacia autem caulina lanceolata ad lineari-lanceolata vel ovata $2.5-7 \mathrm{~cm}$ longa dentata vel laciniata sessilia plus minusve auriculata pilis grossis sparsis. Corolla malvina 12-14 mm longa pilis simplicibus ac glandulosis extra. Pedunculi glabri sine bracteolae. Semina plana elliptica $3.5 \mathrm{~mm}$ longa papillosa rugosa.

HOLOTYPE: WeSTERN AUSTRALIA: Kununurra, M. Lazarides 6780, 7 March 1963 (CANB 123779).

Decumbent to prostrate herb with thin taproot. Stems \pm compressed but becoming terete towards base, to $50 \mathrm{~cm}$ long, glabrous. Leaves mostly cauline but with an ephemeral group of basal leaves; basal leaves obovate to oblanceolate, c. $2 \mathrm{~cm}$ long, tapering very gradually towards base; cauline leaves, lanceolate to linear-lanceolate or occasionally ovate, $2.5-7 \mathrm{~cm}$ long, $5-13 \mathrm{~mm}$ wide, sessile, \pm auriculate, acute, dentate to laciniate or narrowly pinnate-lobed, sparsely pubescent with coarse simple hairs and sometimes minute glandular ones. Flowers in terminal racemes; bracts leaf-like, progressively smaller towards top; peduncles $2-5 \mathrm{~cm}$ long, glabrous, \pm articulate $1-2 \mathrm{~mm}$ below ovary; bracteoles absent. Sepals lanceolate to narrow-oblong, 3-4 $\mathrm{mm}$ long $0.6-0.8 \mathrm{~mm}$ wide, acute, with simple hairs especially along margins, sometimes with few minute glandular hairs, adnate to ovary for c. $3 / 4$ of its length. Corolla mauvish sometimes \pm yellow towards top or pinkish, mostly $12-14 \mathrm{~mm}$ long, simplepubescent outside with some minute glandular hairs, pubescent inside especially towards base, auriculate; anterior pocket almost obsolete; tube 2.5-3 $\mathrm{cm}$ long; superior lobes falcate-narrow-elliptic, $6.5-7.5 \mathrm{~mm}$ long, $1-1.2 \mathrm{~mm}$ wide; inferior lobes narrow-elliptic; wings to $1.5 \mathrm{~mm}$ wide, laciniate, c. $2 / 3$ as long as lobes; connate part of inferior lobes $3-4 \mathrm{~cm}$ long. Stamen filaments linear, c. $2 \mathrm{~mm}$ long; anthers oblong, c. $1 \mathrm{~mm}$ long. Ovary hirsute-pubescent with coarse simple hairs; septum scarcely $1 / 4$ as long as loculus; ovules $8-10$; style 6-7 mm long with few scattered long hairs; indusium transverse- oblong, 1 $\mathrm{mm}$ long, $3 \mathrm{~mm}$ wide, with some scattered simple hairs on both surfaces, convex above with an almost straight orifice beset with white bristles c. $0.5 \mathrm{~mm}$ long on upper lip and much shorter $(0.1-0.2 \mathrm{~mm})$ ones on lower lip. Fruit \pm compressed, ovoid 5-6 mm long, 3-4 mm wide, glabrescent, 2 -valved for c. $3 / 4 \mathrm{~s}$ of its length, gaping, each valve entire. Seed flat, yellowish, elliptic, c. $3.5 \mathrm{~mm}$ long, $1.8 \mathrm{~mm}$ wide, verrucate, granulose, with a prominent rim; wing almost obsolete.

RANGE: Gardner (Kimberley) District of Western Australia; Victoria River District of Northern Territory.

HABITAT: Grasslands on black cracking clay soils.

Discussion: This species differs from $G$. hispida, which appears to be its nearest relative, in the corolla colour, the glabrous stems and peduncles, and the much less pubescent, usually more laciniate narrower leaves. The specimens from Arnhem Land show some very distinct differences from those collected further west, the corolla in particular is much smaller, the sepals shorter and the leaves are not decurrent. 
Selected Specimens (8): Western Australia: Ord River, E. Langfield, 1948 (PERTH): Ord River, K.M. Durack, 4 May 1945 (PERTH). NORTHERN TERRITORY: 29.9 miles $(47.8 \mathrm{~km})$ E of Newry, $G$. Chippendale, 10 May 1959 (NT 6000); 16.9 miles (27 km) NE of Beetaloo HS., G. Chippendale, 10 April 1959 (NT 5470).

Named for the mauve colour of the corolla. Latin malvina = mauve.

G. hispida $R$. Br., Prodr.: 577 (1810).

Lectotype: Northern Territory: Carpentaria, Point S, [i.e. Point Blane], R. Brown, 28 Jan. 1803 (BM). ISOLECTOTYPE: K.*

G. chthonocephala Carolin, sp. nov.

Herba annua radicibus fibrosis. Flores sessiles in axillis foliorum basalium lineari-lanceolatorum atque sic in capitulo super terra dispositi. Sepala linearia. Corolla $1-1.5 \mathrm{~mm}$ longa exalata. Semina orbiculata verrucata c. $0.2 \mathrm{~mm}$ diametro.

HolotyPe: NORTHERn TERritory: Cox River Station, P.K. Latz 7176, 2 July 1977 (NT 574444).

Small annual with fibrous root system and condensed stems. Leaves all basal, linear-lanceolate, to $8 \mathrm{~cm}$ long, to $3 \mathrm{~mm}$ wide, tapering gradually towards base, entire, pubescent when young with simple hairs, glabrescent. Flowers sessile in leaf axils and thus arranged in a pubescent head at ground level; bracteoles absent. Sepals linear, c. $0.5 \mathrm{~mm}$ long, acute, pubescent, adnate to ovary nearly to its summit. Corolla reddish when dry, 1-1.5 mm long, pubescent, with long simple hairs outside, almost glabrous inside; anterior pocket almost obsolete; tube c. $0.5 \mathrm{~mm}$ long; lobes \pm equal, triangular, $0.5-1.0 \mathrm{~mm}$ long, less than 0.5 $\mathrm{mm}$ wide, acute; wings obsolete. Stamen filaments c. $0.5 \mathrm{~mm}$ wide; anthers subglobular, c. $0.1 \mathrm{~mm}$ diam. Ovary densely pubescent with simple and multicellular hairs; septum almost as long as loculus; ovules 30-40; style c. 0.5 $\mathrm{mm}$ long, pubescent; indusium broad-elliptic, c. $0.2 \mathrm{~mm}$ wide, flat, with \pm curved orifice beset with very short bristles. Fruit ellipsoid, $3 \mathrm{~mm}$ long, pubescent with simple and multicellular hairs, distinctly 10-veined, 2-valved, each valve entire and separating from base not through a distinct articulation but where the tissue is weak. Seeds flat, reddish brown with a paler border, orbicular, c. $0.2 \mathrm{~mm}$ diam., verrucate; wing scarcely differentiated.

RANGE: Known only from the type collection.

HABITAT: Damp places.

Discussion: This species is closest to G. subauriculata, from which it differs in the smaller flowers which are grouped into a head at ground level.

The specific epithet refers to the tight groups of flowers at ground level. Greek, chthonos $=$ earth, cephale $=$ head.

G. armstrongiana Vriese, Natuurk. Verh. Holl. Maatsch. Wetensch. Haarlem ser. 2, 10: 138 (1854).

HolOtyPe: NORTHERn TerritORy: Raffles Bay, Armstrong, Aug. $1846(\mathrm{~K}){ }^{*}$ There are two sheets of Armstrong's collection from Port Essington but only one bears the full labelling given by de Vriese. Since he states 'Unicum specimen vidi in Hookeri' this specimen, which agrees with his description and figure, must be the holotype.

G. argillacea Carolin, sp. nov.

Herba caule principali erecto ac ramis decumbentibus ad $70 \mathrm{~cm}$ longis. Folia anguste oblonga ad linearia $2-4.5 \mathrm{~cm}$ longa dentata sessilia glabra. Flores 
pedicellis gracilis ebracteolatis ad $2.5-4 \mathrm{~cm}$ longis in racemis disposita. Corolla 10-12 mm longa pubescens. Capsula obovoidea 3-3.5 $\mathrm{mm}$ longa per duas valvas ad basim dehiscens. Semina elliptica $3 \mathrm{~mm}$ longa laevigata impolita.

HOLOTYPE: NORTHERN TERRITORY: 8 miles $(12.8 \mathrm{~km})$ NE of Mainoru River crossing on Bulman Road, R.C. Carolin 9403, 23 May 1974 (NSW). ISOTYPE: SYD.

Herb with an erect main stem and weak decumbent branches to $70 \mathrm{~cm}$ long. Leaves narrow-oblong to linear, $2-4.5 \mathrm{~cm}$ long, $2.5-6 \mathrm{~mm}$ wide, sessile and sometimes slightly auriculate, obscurely dentate with blunt teeth, with slightly recurved margins, glabrous. Flowers in leafy racemes; bracts similar to lower leaves but usually narrower and often longer; pedicels $2.5-4 \mathrm{~cm}$ long, slender, glabrous, not articulate; bracteoles absent. Sepals lanceolate, $2.5 \mathrm{~mm}$ long, 0.5 $\mathrm{mm}$ wide, acute, glabrous but for some simple hairs terminating the marginal denticles, adnate to ovary for $3 / 4$ its length. Corolla brownish-yellow (becoming pale purple on drying), 10-12 mm long, pubescent outside with \pm appressed simple hairs, with very few simple hairs inside, auriculate; anterior pocket obsolete; tube $3 \mathrm{~mm}$ long; superior lobes narrow-oblong, 4-5 mm long, 0.7-0.8 $\mathrm{mm}$ wide; inferior lobes oblong-ovate, $2.5 \mathrm{~mm}$ long, $0.8 \mathrm{~mm}$ wide; wings c. 1 $\mathrm{mm}$ wide. Stamen filaments linear, $1.5 \mathrm{~mm}$ long; anthers narrow-oblong, $1 \mathrm{~mm}$ long. Ovary with a few strigose hairs; septum scarcely $1 / 4$ as long as loculus; ovules 6-8; style pubescent especially towards base, c. $5 \mathrm{~mm}$ long; indusium depressed-obovate, $1 \mathrm{~mm}$ long, $2.5 \mathrm{~mm}$ wide, glabrous on upper surface, pubescent on lower surface, with a slightly concave orifice beset with white bristles c. $0.3 \mathrm{~mm}$ on upper lip and shorter ones on lower lip. Fruit obovoid, 3-3.5 mm long, 2-2.5 mm wide, 2-valved almost to base, each valve entire. Seed elliptic, $3 \mathrm{~mm}$ long, $2.5 \mathrm{~mm}$ wide, minutely reticulate-alveolate or smooth and dull to naked eye, with a prominent rim; wing obscure except near the funicle.

RANGE: Only known from the type collection.

HABITAT: Melaleuca scrub on calcareous clays.

The specific epithet refers to the heavy clays on which the type collection was growing. Latin, argillaceus = pertaining to clay.

\section{G. potamica Carolin, sp. nov.}

Herba decumbens vel adscendens ad $20 \mathrm{~cm}$. Caules pilis simplicibus arcuatis obtecti. Folia basalia oblanceolata ad obovata $2-8 \mathrm{~cm}$ longa dentata pubescentia pilis simplicibus grossis. Flores in racemis herbaceis vel umbellis ac in pedunculis glandulosis $10-15 \mathrm{~mm}$ longa dispositi. Pili glandulosi capitibus nigris vel fuligineis. Sepala pilis glandulosis conferte obtecta. Corolla flava 11-15 mm longa. Semina plana elliptico-obovata $2-3 \mathrm{~mm}$ longa verrucata exalata.

HolotYPe: 24 m W Liverpool River crossing, J. Must 1069, 27 June 1972 (NT).

Decumbent to ascending herb to $20 \mathrm{~cm}$. Stems to $40 \mathrm{~cm}$, pubescent with arcuate simple hairs. Basal leaves in an ephemeral rosette, tapering gradually towards base into an indistinct petiole, obtuse, dentate to almost entire, with coarse simple hairs; cauline leaves smaller, often broader and quite sessile, sometimes with a large basal lobe on one side only. Flowers in leafy racemes or condensed into umbels or rarely axillary in the basal leaves; bracts similar to cauline leaves but smaller and narrower; peduncles $10-15 \mathrm{~mm}$ long, pubescent with black- or dark brown-capped glandular hairs and some simple hairs, ebracteolate, not articulate. Sepals oblong, 1-1.5 mm long, c. $0.5 \mathrm{~mm}$ wide, 
pubescent as peduncles, acute, adnate to ovary almost to its summit. Corolla yellow with brownish throat, 11-15 mm long, glandular pubescent outside, simple pubescent in throat, auriculate; anterior pouch obsolete; superior lobes oblanceolate to narrow-oblong, 5-6 mm long, $1 \mathrm{~mm}$ wide; wings $1-1.5 \mathrm{~mm}$ wide; inferior lobes oblong, $2.5-3 \mathrm{~mm}$ long, $0.6-0.8 \mathrm{~mm}$ wide; connate part of inferior lobes 4-5 mm long. Stamen filaments linear, $3 \mathrm{~mm}$ long; anthers narrow-oblong, $3 \mathrm{~mm}$ long. Ovary glandular pubescent; septum very short; ovules 8-10; style 4-5 mm long, pubescent; indusium semi-orbicular, $4 \mathrm{~mm}$ diam., yellowish brown, with a straight orifice beset with white bristles c. 0.3 $\mathrm{mm}$ long. Fruit ellipsoid to globular, $3-5 \mathrm{~mm}$ long; valves 2 , entire, gaping to the base. Seeds flat, elliptic-obovate, $2.5 \mathrm{~mm}$ long, verrucate, with a distinct rim; wing obsolete except close to funicle.

RANGE: Arnhem Land.

HABITAT: River flats possibly extending into the forests on sandy soils.

Discussion: Shows a close resemblance to those species originally included in the genus Calogyne particularly to $C$. holtzeana but the unbranched style clearly distinguishes it.

SPECIMENS EXAMINED: NORTHERN TERRITORY: Liverpool River, F. Duncan, 1975 (SYD); $45 \mathrm{~km}$ upstream from the mouth of the Liverpool River, F. Duncan 803, 2 May 1975 (SYD).

The specific epithet refers to the river flats in which this species grows. Latinised Greek potamicus = pertaining to a river.

G. porphyrea (Carolin) Carolin, comb. nov.

BASIONYM: Calogyne porphyrea Carolin, Brunonia 2: 4 (1979).

G. pilosa (R. Br.) Carolin, comb. nov.

BASIONYM: Calogyne pilosa R. Br., Prodr.: 579 (1810).

G. neglecta (Carolin) Carolin, comb. nov.

BASIONYM: Calogyne neglecta Carolin, Brunonia 2: 7 (1979).

G. heteroptera (F. Muell.) Carolin, comb. nov.

BASIONYM: Calogyne heteroptera F. Muell., Fragm. 10: 43 (1876).

G. holtzeana (Specht) Carolin, comb. nov.

Basionym: Calogyne holtzeana Specht, American-Australian Scientific Expedition to Arnhem Land 3: 309 (1958).

G. heppleana ( $W$. Fitzg.) Carolin, comb. nov.

Basionym: Calogyne heppleana W. Fitzg., J. \& Proc. Roy. Soc. Western Australia 3: 214 (1918).

G. symonii (Carolin) Carolin, comb. nov.

BASIONYM: Calogyne symonii Carolin, Brunonia 2: 12 (1979).

G. purpurea (F. Muell.) Carolin, comb. nov.

BASIONYM: Calogyne purpurea F. Muell., Fragm. 8: 57 (1873).

G. quadrifida (Carolin) Carolin, comb. nov.

BASIONYM: Calogyne quadrifida Carolin, Brunonia 2: 15 (1979). 


\section{G. kakadu Carolin, sp. nov.}

Herba prostrata rosulifera stolonifera. Folia 6-15 $\mathrm{mm}$ longa anguste oblongoelliptica ad oblanceolata glabrescentia plerumque acuta attenuata ad basim. Flores solitares in axillis foliorum. Sepala inaequalia. Corolla porphyrea $3 \mathrm{~mm}$ longa lobis aequalis. Ovarium obconicum.

HolOtyPe: NORTHERN Territory: Kakadu National Park, Site 80, L.A. Craven 6176, 30 May 1980 (CANB 309160). IsOTYPE: SYD.

Protrate herb with rosettes of leaves and stolons to $18 \mathrm{~cm}$ long. Leaves thick, narrow-oblong, c. $3 \mathrm{~mm}$ wide, tapering very gradually towards base, mostly acute, pubescent with soft fine simple hairs when young but glabrescent when mature, with a tuft of silvery axillary hairs. Flowers solitary in leaf axils; bracteoles absent; peduncles to $12 \mathrm{~mm}$ long, pubescent. Sepals narrow-deltoid to ovate, pubescent; anterior sepal c. $1.5 \mathrm{~mm}$ long, the others c. $0.5 \mathrm{~mm}$ long. Corolla red, to $2 \mathrm{~mm}$ long, pubescent outside with simple hairs; lobes equal, ovate, c. $1 \mathrm{~mm}$ long, darker towards base; wings and auricles absent. Stamen filaments linear, c. $1 \mathrm{~mm}$ long; anthers narrow-oblong, c. $0.5 \mathrm{~mm}$ long. Ovary obconic, acute towards base, 2-3 mm long; septum very short, extended into a free-central placenta bearing about 30 ovules irregularly arranged; style c. $1 \mathrm{~mm}$ long, glabrous; indusium globular with a few very short bristles on lips. Seeds not seen.

RANGE: Known only from the type collection.

HABITAT: Damp places in sandy-organic soil.

Discussion: This is a species with a superficial resemblance to G. pumilio but in G. kakadu the leaves taper gradually towards the base, the hairs are simple and not stellate and the ovary is attenuate at the base.

The species is named for its locality and the epithet is an undeclinable Aboriginal word.

\section{Excluded names}

G. glandulifera Vriese, Natuurk. Verh. Holl. Maatsch. Wetensch. Haarlem ser. 2, 10: 129 (1854). = Diaspasis filifolia $R$. $B r$.

LECTOTYPE: In solo turfoso inter frutices prope urbiculam Albany, 4 Oct. 1840, L. Preiss 2032 (LD 0447). IsOlectoTYPE: L903,311-. ..297. De Vriese thought that Preiss 2032 was a mixed collection. He referred part to $G$. armeriaefolia DC. and part to $G$. glandulifera Vriese. This collection appears to be homogeneous. It is not possible to determine which part he refers to which species.

\section{References}

Carolin, R.C. (1967) The genus Velleia Sm. Proc. Linn. Soc. New South Wales 92: $27-57$.

Carolin, R.C. (1990) Phylogeny, taxonomy and nomenclatural notes in the genus Scaevola (Goodeniaceae) and its synonyms. Telopea 3(4):477-515

Peacock, W.J. (1962) Chromosome races in G. bellidifolia Sm. Proc. Linn. Soc. New South Wales 87: 271-277.

Peacock, W.J. (1963) Chromosome numbers and cytoevolution in the Goodeniaceae. Proc. Linn. Soc. New South Wales 88: 8-27.

Rajput, M.T.M. \& Carolin, R.C. (1988) Nomenclatural notes, new taxa and the systematic arrangement in the genus Dampiera (Goodeniaceae). Telopea 3(2): 183-216.

Stafleu, F.A. \& Cowan, R.S. (1976) Taxonomic Literature vol. 1. (Junk: The Hague). 


\section{Index}

Species page

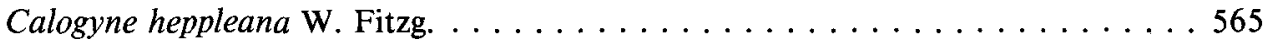

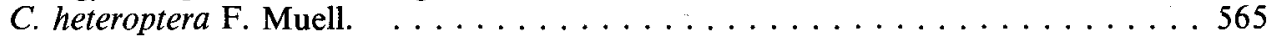

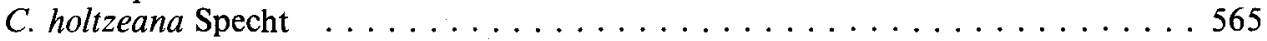

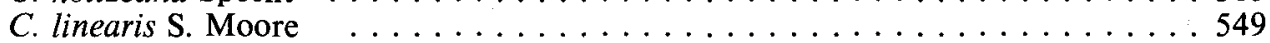

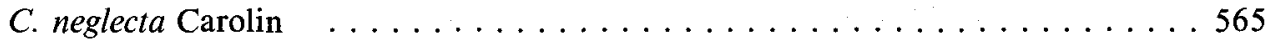

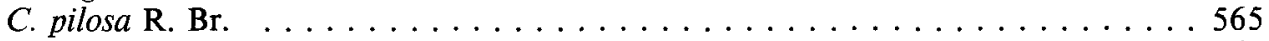

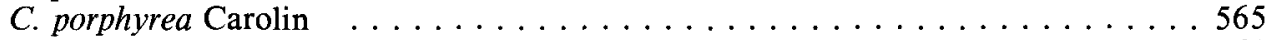

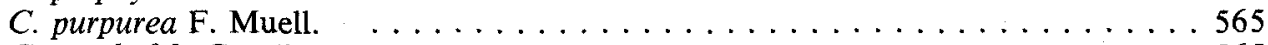

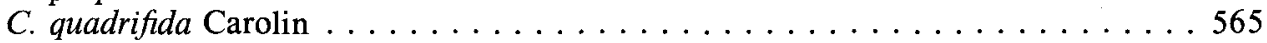

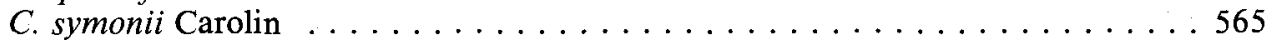

Catospermum goodeniacum (F. Muell.) Benth. . . . . . . . . . . . . . . 529

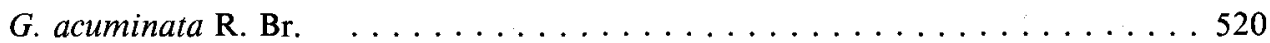

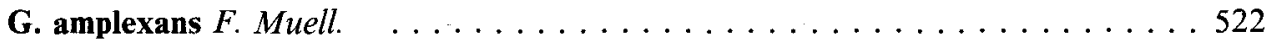

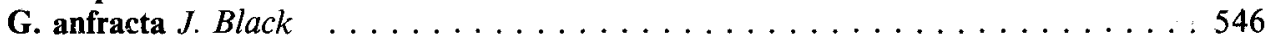

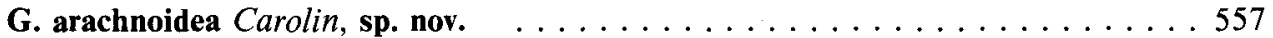

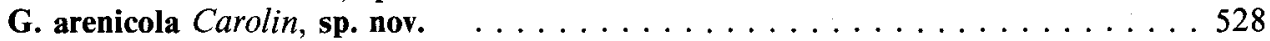

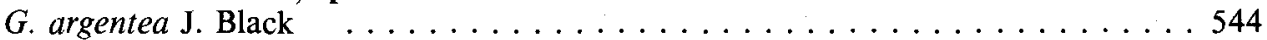

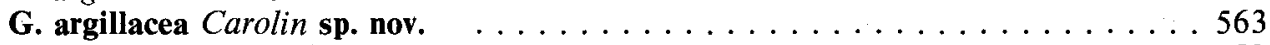

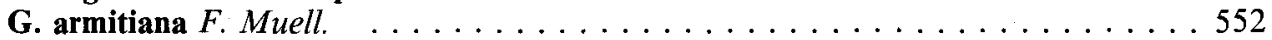

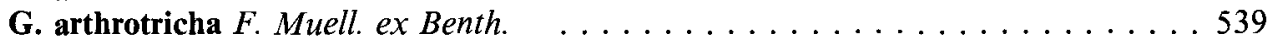

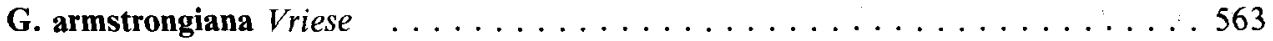

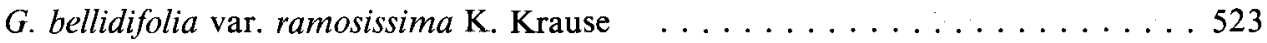

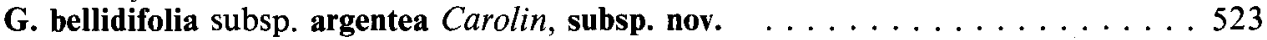

G. berardiana (Gaudich.) Carolin . . . . . . . . . . . . . . . . . . . 549

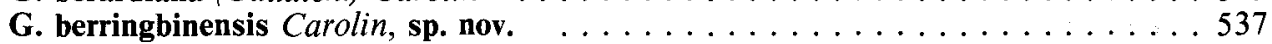

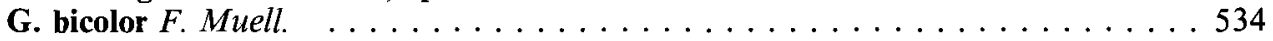

G. bonneyana F. Muell. . . . . . . . . . . . . . . . . . . . 539

G. brachypoda ( $F$. Muell. ex Benth.) Carolin, comb. et stat. nov. . . . . . . . . 558

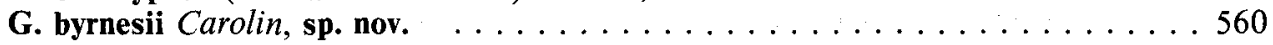

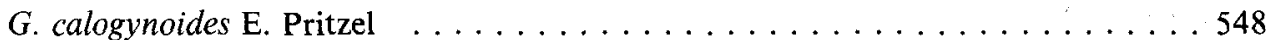

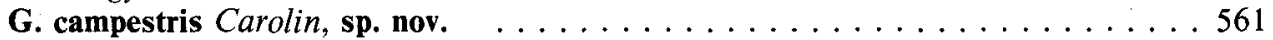

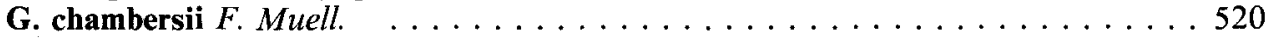

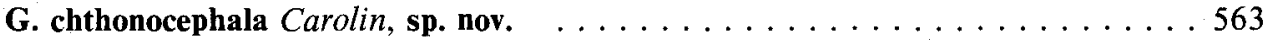

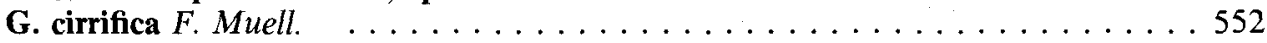

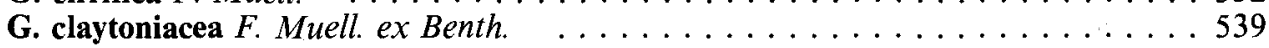

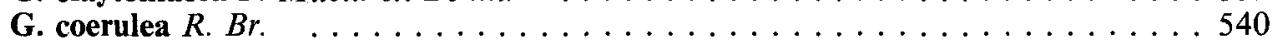

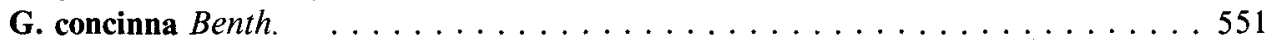

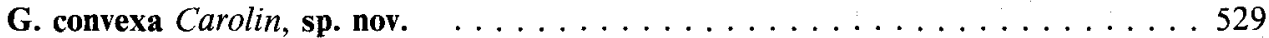

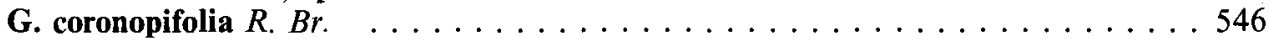

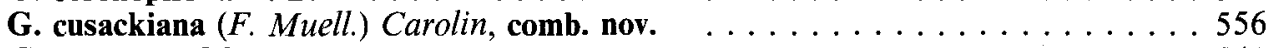

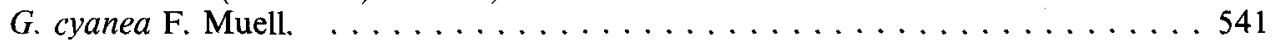

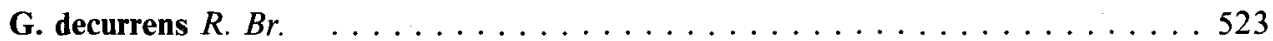

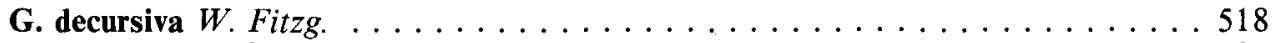

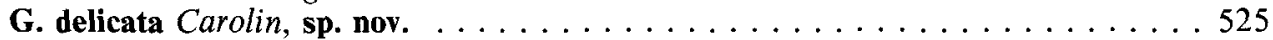

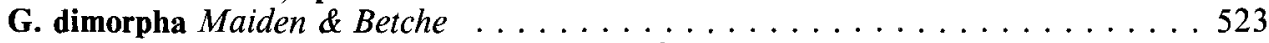

G. dimorpha var. angustifolia Maiden \& Betche $\ldots \ldots \ldots \ldots \ldots \ldots \ldots \ldots \ldots$

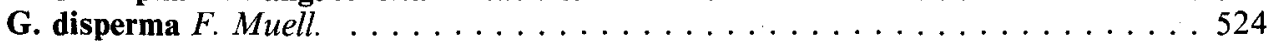

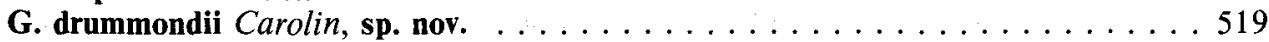

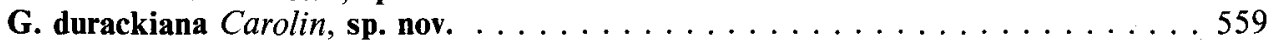




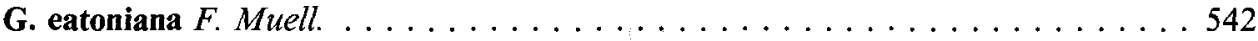

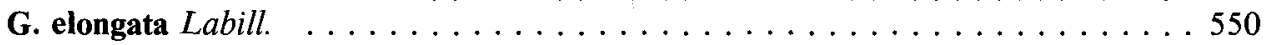

G. erecta Ewart . . . . . . . . . . . . . . . . . . . 539

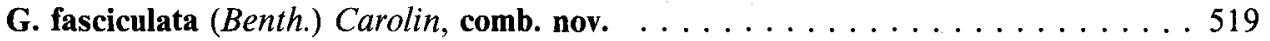

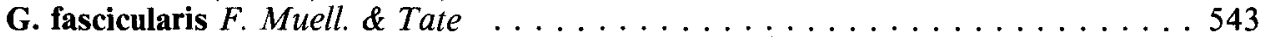

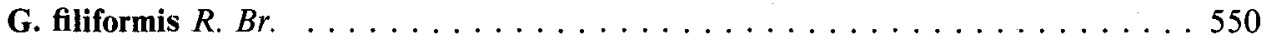

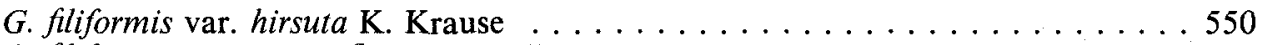

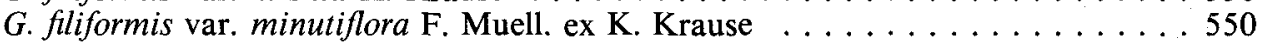

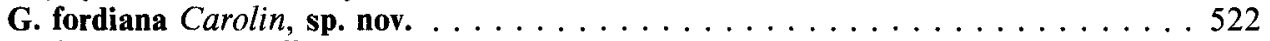

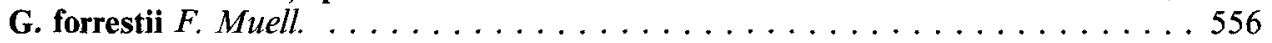

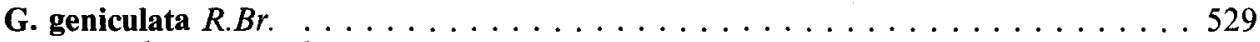

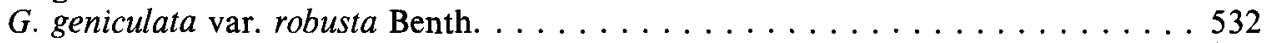

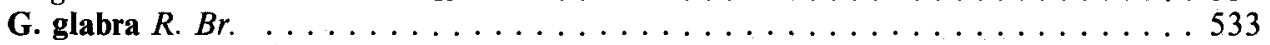

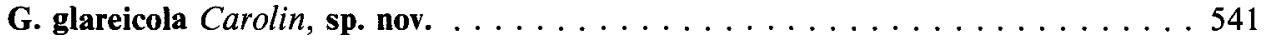

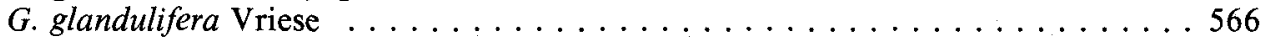

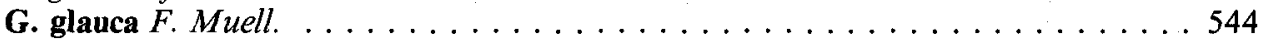

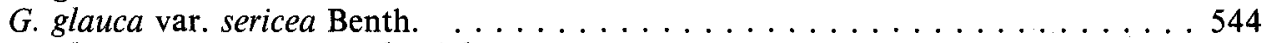

G. glauca F. Muell. var. glandulosa Benth. . . . . . . . . . . . . . . . 549

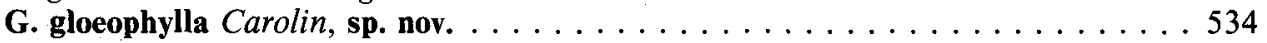

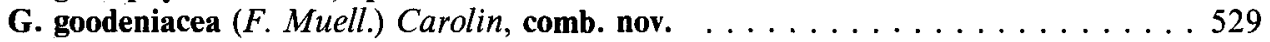

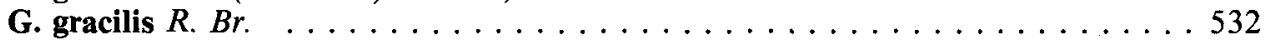

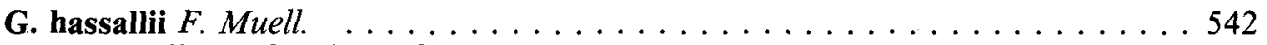

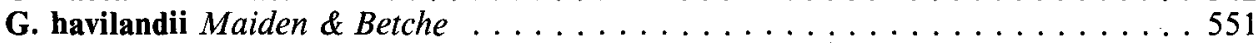

G. hederacea subsp. alpestris (K. Krause) Carolin, comb. nov. . . . . . . . . . 529

G. hederacea var. alpestris K. Krause . . . . . . . . . . . . . . . . 529

G. hederacea var. cordifolia Ewart . . . . . . . . . . . . . . . . . . 529

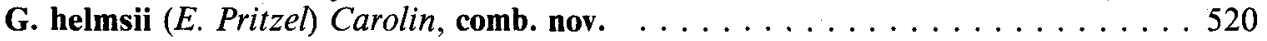

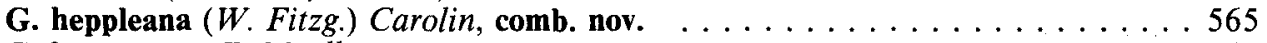

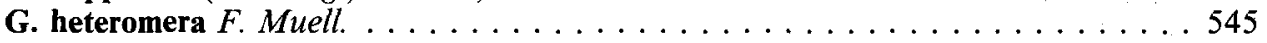

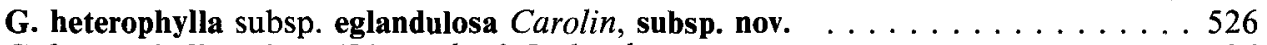

G. heterophylla subsp. 'B' Jacobs \& Pickard . . . . . . . . . . . . . . . . 526

G. heterophylla subsp. teucriifolia (F. Muell.) Carolin, comb. nov. . . . . . . . 527

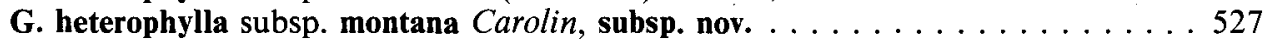

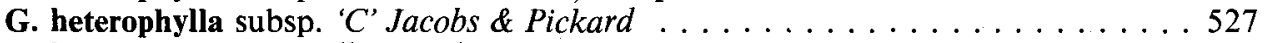

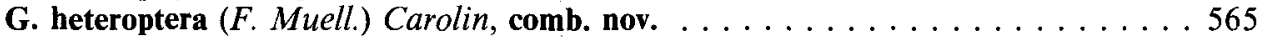

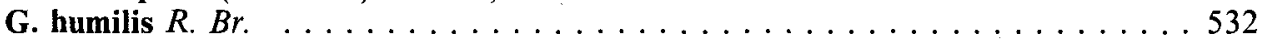

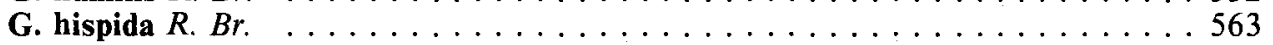

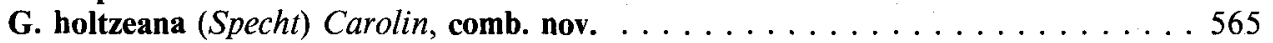

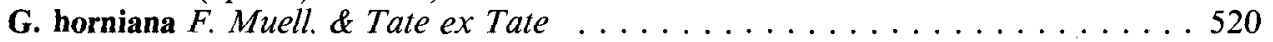

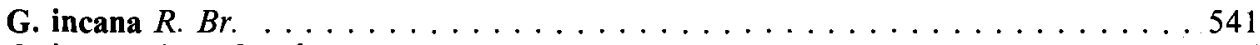

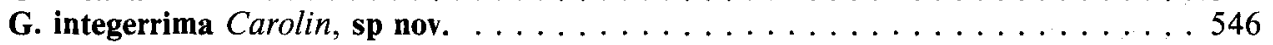

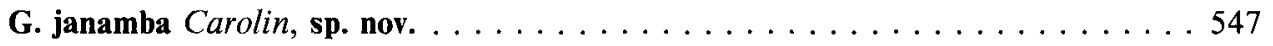

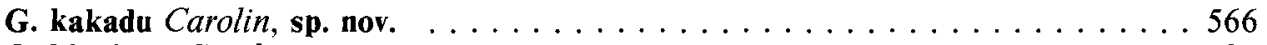

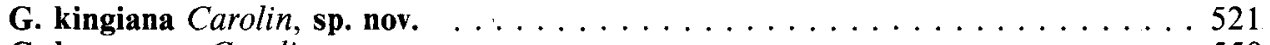

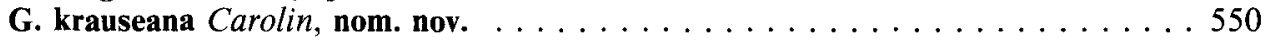

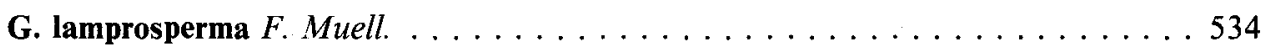

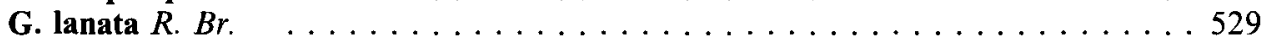

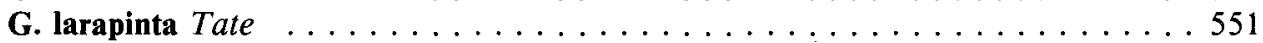

G. Iaytoniana (orthographic variant of G. claytoniacea)
G. leiosperma Carolin, sp. nov. $\ldots \ldots \ldots \ldots \ldots \ldots \ldots \ldots \ldots \ldots \ldots \ldots \ldots \ldots \ldots$

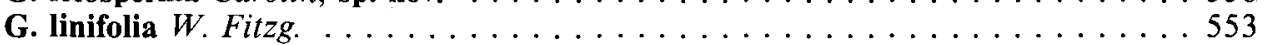




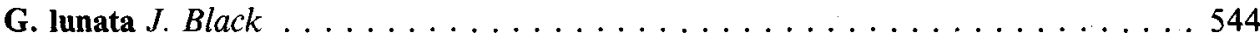

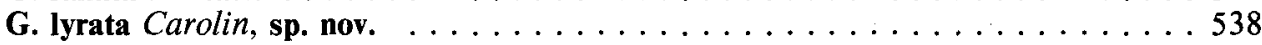

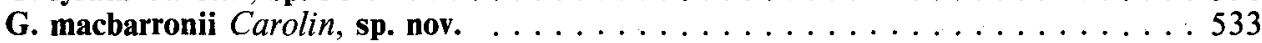

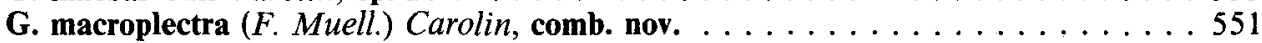

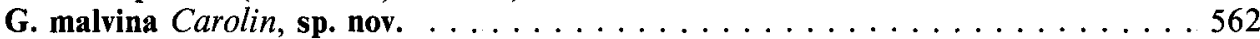

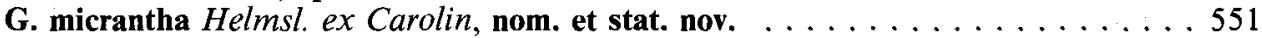

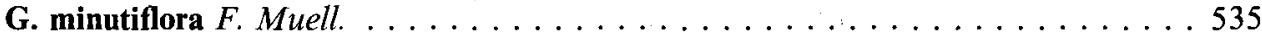

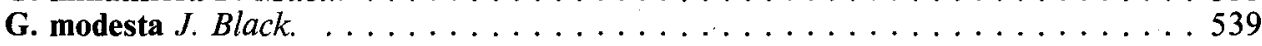

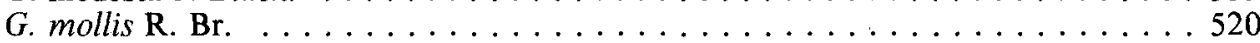

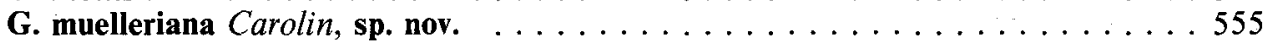

G. mooreana K. Krause . . . . . . . . . . . . . . . . . . . . . . . . . . . 529

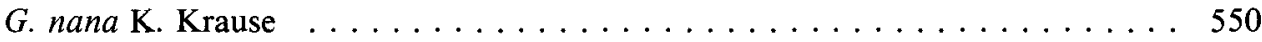

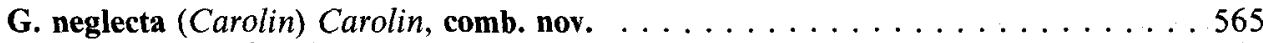

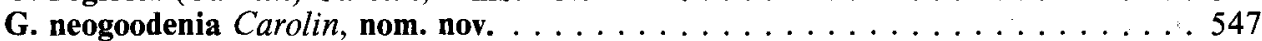

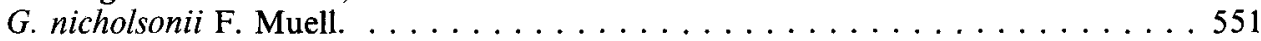

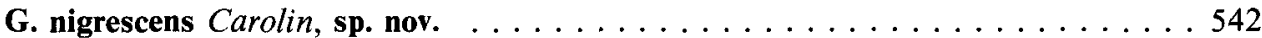

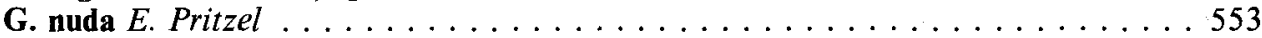

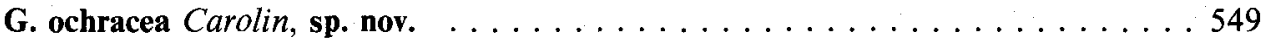

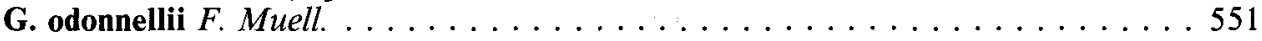

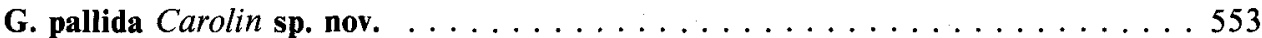

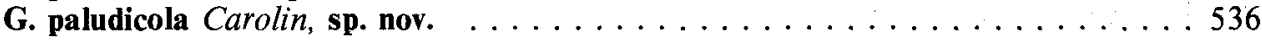

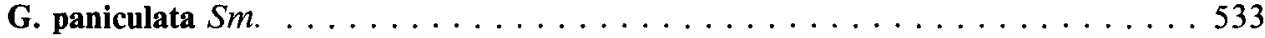

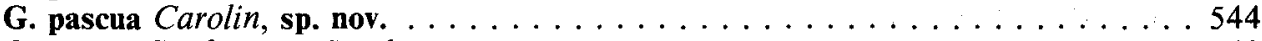

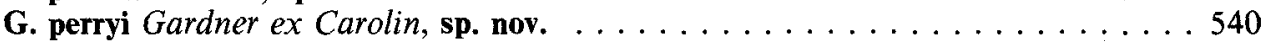

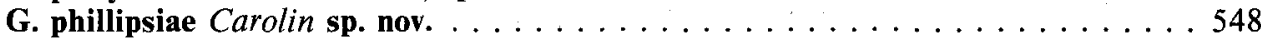

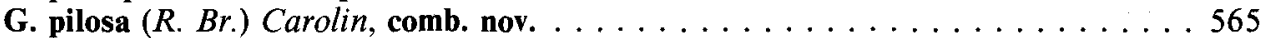

G. pinifolia Vriese . . . . . . . . . . . . . . . . . . . . . . . . 519

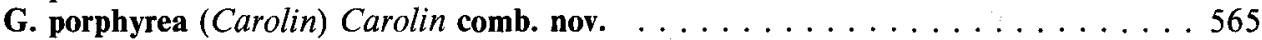

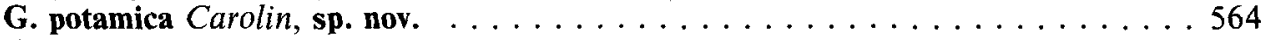

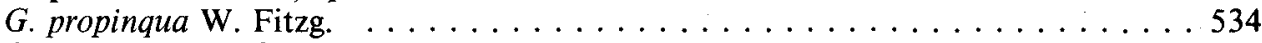

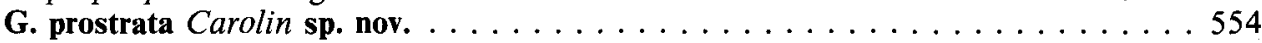

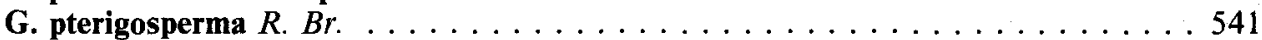

G. pterygosperma (orthographic variant of $G$. pterigosperma)

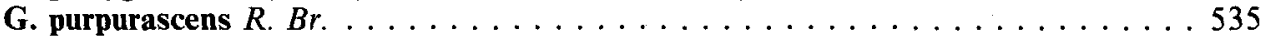

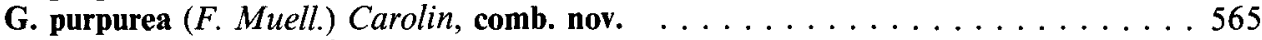

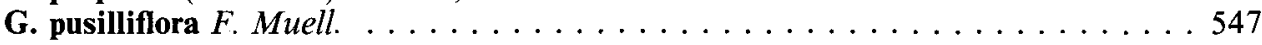

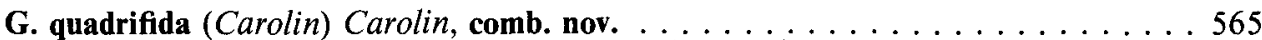

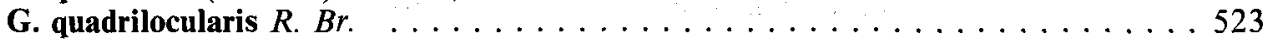

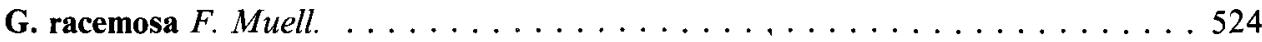

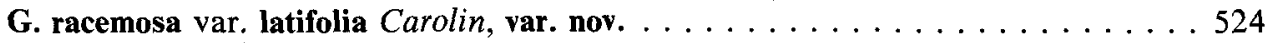

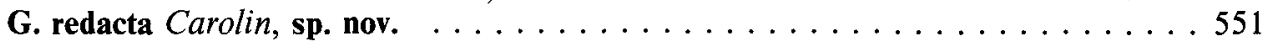

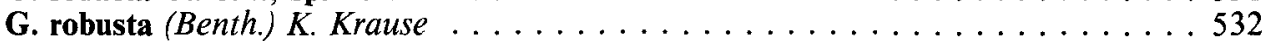

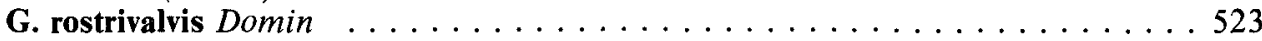

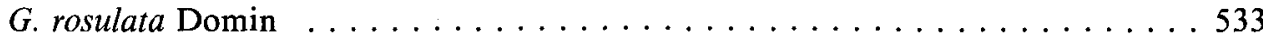

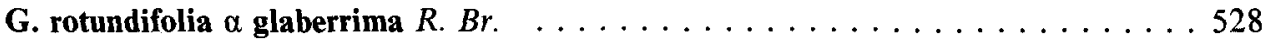

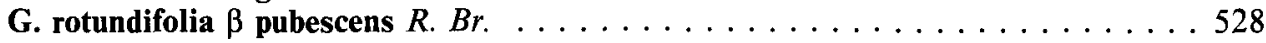

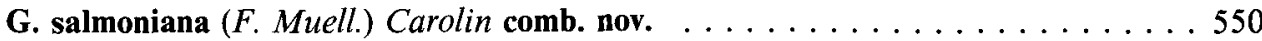

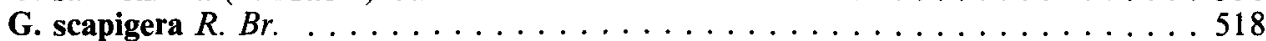

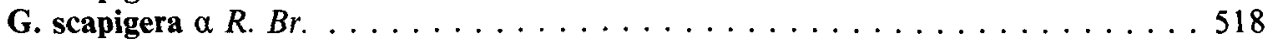

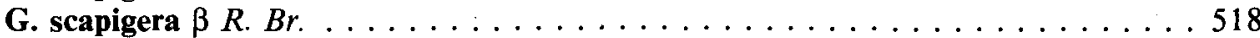

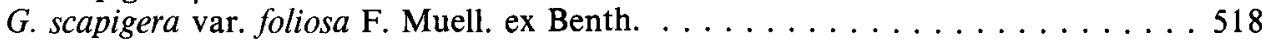

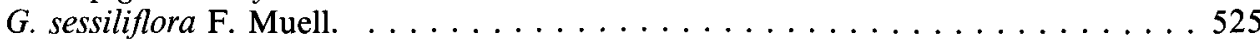




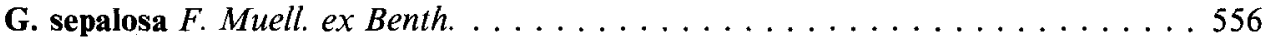

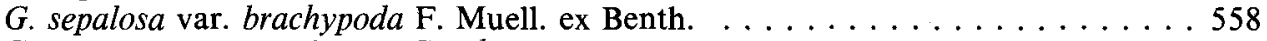

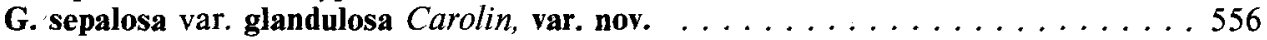

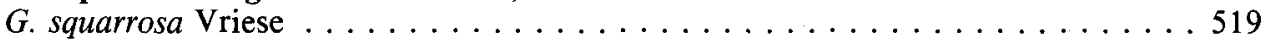

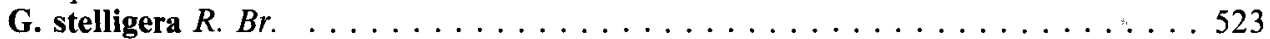

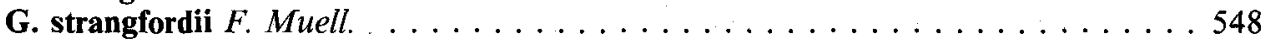

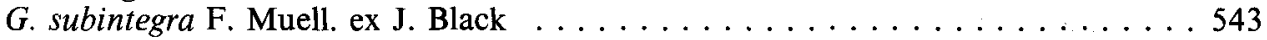

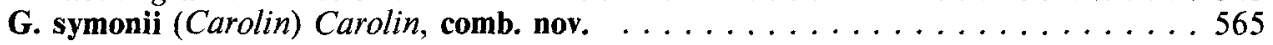

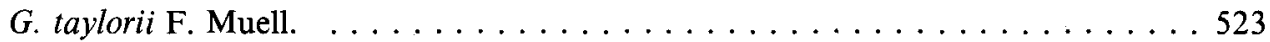

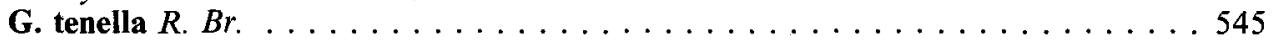

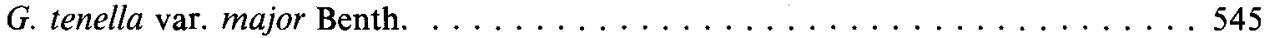

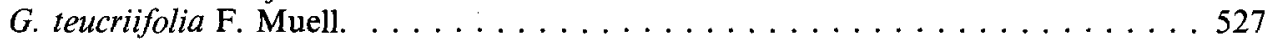

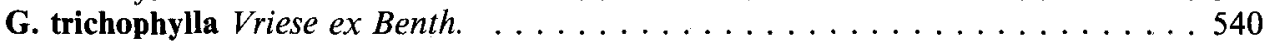

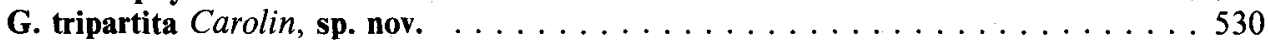

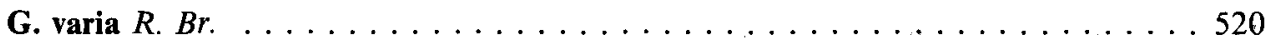

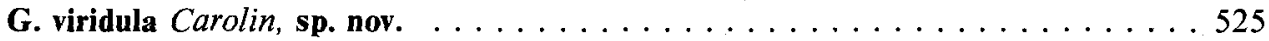

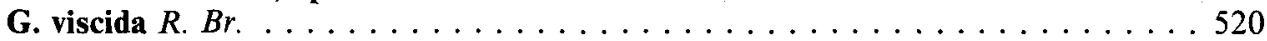

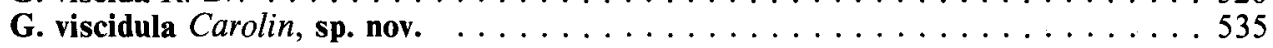

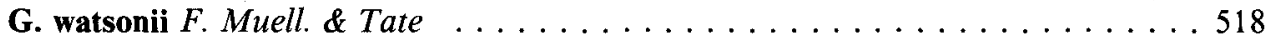

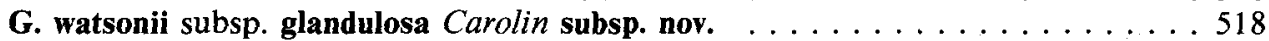

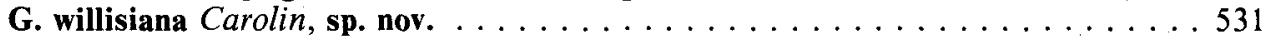

G. xanthosperma F. Muell. . . . . . . . . . . . . . . . . . . . 529

Neogoodenia minutiflora Gardner \& George . . . . . . . . . . . . . . . 547

Scaevola fasciculata Benth. . . . . . . . . . . . . . . . . . . . . 519

S. goodeniacea F. Muell. . . . . . . . . . . . . . . . . . . . 529

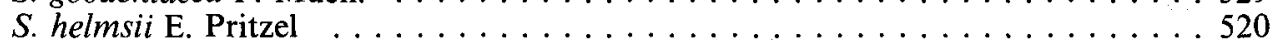

Symphyobasis macroplectra (F. Muell.) K. Krause . . . . . . . . . . . . . 551

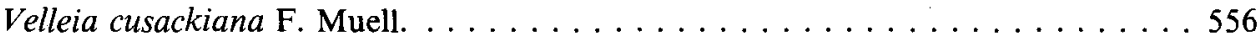

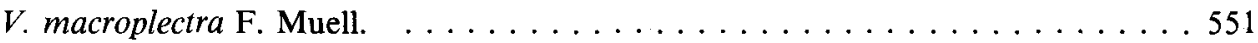

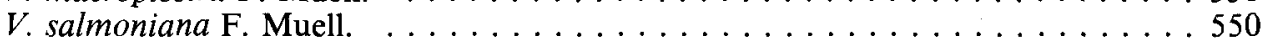

Manuscript received 13 May 1988

Manuscript accepted 12 June 1989 